\begin{abstract}
Universidade de São Paulo
FaCuldade de Filosofia, Letras e CiênCias Humanas

DEPARTAMENTO DE LETRAS MODERNAS

Programa de Pós-Graduação em Língua, Literatura e Cultura

ITALIANAS
\end{abstract}

Mayara Da SiLva NeTO

Pedir em italiano: um estudo sobre a percepção da cortesia por parte de falantes nativos e aprendizes brasileiros

DisSERTAÇÃO DE MESTRAdO

Versão corrigida

SÃo PAULO

2018 


\section{Pedir em italiano: um estudo sobre a percepção da cortesia por parte de falantes nativos e aprendizes brasileiros}

Versão corrigida

Dissertação de mestrado apresentada ao Programa de pós-graduação em Língua Literatura e Cultura Italianas do Departamento de Letras Modernas da Faculdade de Filosofia, Letras e Ciências Humanas da Universidade de São Paulo, como parte dos requisitos necessários à obtenção do título de mestre.

Orientadora: Profa. Dra. Elisabetta A.R.M.C. Santoro

SÃo PAULO

2018 
Autorizo a reprodução e divulgação total ou parcial deste trabalho, por qualquer meio convencional ou eletrônico, para fins de estudo e pesquisa, desde que citada a fonte.

\section{Catalogação na Publicação}

Serviço de Biblioteca e Documentação

Faculdade de Filosofia, Letras e Ciências Humanas da Universidade de São Paulo

Silva Neto, Mayara da

Pedir em italiano: um estudo sobre a percepção da cortesia por parte de falantes nativos e aprendizes brasileiros / Mayara da Silva Neto ; orientadora Elisabetta A. R. M. C. Santoro. - São Paulo, 2018. $138 \mathrm{f}$.

Dissertação (Mestrado)- Faculdade de Filosofia, Letras e Ciências Humanas da Universidade de São Paulo. Departamento de Letras Modernas. Área de concentração: Língua, Literatura e Cultura Italiana.

1. pedidos. 2. italiano. 3. cortesia. 4. falantes nativos. 5. aprendizes brasileiros. I. Santoro, Elisabetta A. R. M. C. , orient. II. Título. 


\section{AGRADECIMENTOS}

À minha orientadora, Elisabetta Santoro, que participou de quase toda a minha formação acadêmica. Obrigada pelo apoio e paciência, pela presença, por estar sempre disposta a colaborar de alguma maneira e pelas tantas ocasiões de aprendizado.

Aos professores Luiz Antonio da Silva e Zulma Kulikowski, por terem acompanhado meu trabalho desde a Iniciação Científica, apontando sempre muito gentilmente os aspectos que deveria aprimorar.

Aos colegas do Grupo de Pesquisa Pragmática (Inter)Linguística, Cross-cultural e Intercultural, com quem a troca de experiências tem me ajudado a ver com mais clareza aspectos dos projetos que venho desenvolvendo.

À Ada Bier, que mesmo às voltas com as atividades dos tantos alunos das disciplinas que cursei na $\mathrm{Ca}$ ' Foscari, deu-me orientações muito importantes na fase de elaboração dos questionários.

Aos professores Paula Freitas (UFPR), Yuri Brunello e Simone Lopes (UFC), Elena Nuzzo (Università di Roma Tre) e Paola Leone (Università del Salento) e a Adriana Mendes, Cristine Tedesco, Cristhian Herrera, Marcela Xoxi e Manuela Lunati pela enorme ajuda com a coleta dos dados no Brasil e na Itália.

Ao Roger Carrer e ao Prof. Dr. Altay Souza (Unifesp), pela inestimável ajuda com a análise estatística dos dados que coletei.

Aos meus pais, que confiaram nas minhas decisões e foram sempre amorosos e positivos durante esse percurso. Agradeço especialmente à minha mãe, que muitas vezes leu ou ouviu pacientemente partes da minha dissertação.

A Teresa Guastaferro e Lorenza Fusi, por me ouvirem e serem sempre tão queridas onde quer que estejamos.

A Francesca Rosso, Mara Mautone e Vitaliana Atria, pela generosidade, pelas risadas, pelos experimentos culinários e pela amizade que construímos.

Às ragazze della stanza davanti, Annamaria Saponara e Federica Cinalli, pela amizade, por me encherem de "mimos" e terem deixado mais leves alguns dos momentos mais difíceis do percurso que resultou nesta dissertação. 
À CAPES, por ter financiado minha pesquisa, e à União Europeia que, por meio do Programa Erasmus Mundus, proporcionou-me um período de intercâmbio na Università Ca' Foscari Venezia. 
E é inútil procurar encurtar caminho e querer começar já sabendo que a voz diz pouco [...]. Pois existe a trajetória, e a trajetória somos nós mesmos. Em matéria de viver, nunca se pode chegar antes.

Clarice Lispector

Non dobbiamo mai dimenticare che la lingua non è semplicemente uno strumento di comunicazione funzionale, è anche un'arma. Padroneggiare la lingua è una cosa che ha a che vedere con la nostra presa sul mondo. E lo stupore che spesso si prova di fronte al suo uso improprio, se non si ferma solo a quello, è miope, non arriva alla sostanza del problema.

Tullio De Mauro 


\section{RESUMO}

O pedido, no âmbito da Pragmática cross-cultural, tem sido estudado por diversos pesquisadores, tanto por ser um dos exemplos mais claros de que é possível "fazer coisas com as palavras", como prevê a Teoria dos Atos de Fala (Austin, 1962), quanto por seu potencial de ameaçar a face positiva de quem o profere e negativa de quem o recebe, conforme postularam Brown e Levinson (1987). Tendo em vista esses pressupostos, a pesquisa aqui apresentada teve o intuito de investigar a percepção que aprendizes brasileiros de italiano e falantes nativos dessa língua têm da cortesia linguística presente em pedidos realizados em italiano, a fim de verificar se há semelhanças ou disparidades nas percepções relatadas pelos diferentes grupos e quais são os elementos que podem motivar essas percepções. Para tal, uma amostra de oito pedidos, gravados em áudio e vídeo, foi apresentada aos informantes brasileiros e italianos, que deveriam indicar, em uma escala de 1 a 5, qual o nível de cortesia neles presente, além de indicar, em um conjunto de 19 variáveis, o quanto elas influenciaram a percepção relatada. O corpus coletado é composto por 40 aprendizes brasileiros e 51 italianos e, a partir da análise dos dados, concluímos que i) quatro dos oito pedidos avaliados pelos informantes suscitaram percepções análogas e, consequentemente, outros quatro pedidos causaram percepções diversas; ii) algumas variáveis (modificadores de força ilocucionária e aspectos como a entoação) tiveram impacto significante sobre a percepção da cortesia em geral e, quanto a cada pedido em específico, que nem sempre a presença de modificadores de força ilocucionária influencia a percepção da cortesia, podendo também a ausência desses elementos ter um impacto positivo ou negativo. Também concluímos que uma grande quantidade de modificadores não necessariamente resulta em uma alta percepção da cortesia.

Palavras-chave: pedidos; cortesia; língua italiana; aprendizes brasileiros; italianos. 


\begin{abstract}
The request, in the context of cross-cultural Pragmatics, has been studied by several researchers, both for being one of the clearest examples of the possibility of "doing things with words", as predicted by the Theory of Speech Acts (Austin, 1962), as well as for its potential to threaten the positive face of the speaker and the negative face of the hearer, as postulated by Brown and Levinson (1987). In view of these presuppositions, the research presented here was intended to investigate how Brazilians learners of Italian and native speakers of this language evaluate the linguistic politeness in requests made in Italian, in order to verify if there are similarities or disparities in the perceptions reported by the different groups and what are the elements that can motivate these perceptions. To do this, a sample of eight requests, recorded in audio and video, was presented to Brazilian and Italian informants, who were asked to indicate, on a scale of 1 to 5 , the level of politeness of those speech acts, besides indicating, in a set of 19 variables, how much they influenced the reported perception. The corpus collected is composed of 40 Brazilians and 51 Italians and, based on data analysis, we concluded that i) four out of eight requests evaluated by the informants presented similar perceptions and, consequently, four other requests caused different perceptions; ii) some variables (modifiers and aspects such as intonation) had a significant impact on the perception of politeness in general. For each specific request, we concluded that the presence of modifiers does not always influence the perception of politeness, and that the absence of such elements may also have a positive or negative impact. Finally, it was possible to notice that a large number of modifiers does not necessarily result in a high perception of politeness.
\end{abstract}

Keywords: requests; politeness; Italian language; Brazilian learners; Italians. 


\begin{abstract}
La richiesta, nel contesto della Pragmatica cross-culturale, è stata studiata da diversi ricercatori, sia perché è uno degli esempi più chiari dell'idea che sia possibile "fare cose con le parole" (Austin, 1962 ), sia per il fatto di minacciare la faccia positiva del parlante e quella negativa del destinatario, come postulato da Brown e Levinson (1987). In base a questi presupposti, la ricerca qui presentata ha avuto lo scopo di indagare sulla percezione che gli studenti brasiliani di italiano e parlanti nativi di questa lingua hanno della cortesia linguistica presente in delle richieste in italiano per verificare se ci sono somiglianze o disparità nelle percezioni riportate dai diversi gruppi e quali sono gli elementi che possono motivare queste percezioni. A tale scopo, un campione di otto richieste, registrate in audio e video, è stato presentato a informatori brasiliani e italiani, che dovevano indicare, su una scala da 1 a 5, il livello di cortesia percepita, oltre a indicare in un set di 19 variabili quanto abbiano influenzato la percezione riportata. Il corpus raccolto consiste di 40 apprendenti brasiliani di italiano e 51 italiani. Dopo l'analisi dei dati, abbiamo concluso che i) quattro tra le otto richieste valutate dagli informatori hanno suscitato percezioni simili e, pertanto, quattro richieste hanno suscitato percezioni diverse; ii) alcune variabili (modificatori di forza illocutoria e aspetti come l'intonazione) hanno avuto un impatto significativo sulla percezione della cortesia in generale e, per quanto riguarda le richieste in specifico, non sempre la presenza di modificatori forza illocutoria è in grado di influenzare la percezione della cortesia, ma anche l'assenza di tali elementi può avere un impatto positivo o negativo. Abbiamo anche concluso che un gran numero di modificatori non necessariamente si traduce in un'alta percezione della cortesia.
\end{abstract}

Parole-chiave: richieste; Cortesia linguistica; lingua italiana; apprendenti brasiliani; italiani 


\section{LISTA DE FIGURAS}

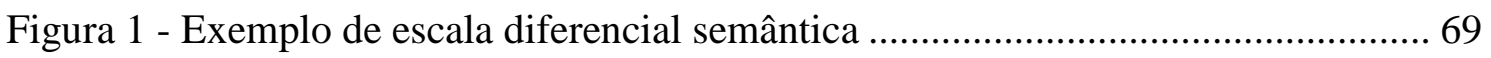

Figura 2 - Vídeo 1 e escala de avaliação do nível de cortesia ......................................... 73

Figura 3 - Pergunta número 2 (modificadores lexicais) .............................................. 78

Figura 4 - Pergunta número 3 (modificadores morfossintáticos) …............................. 79

Figura 5 - Pergunta número 4 (grau de familiaridade) ................................................ 79

Figura 6 - Pergunta número 5 (grau de imposição) ..................................................... 80

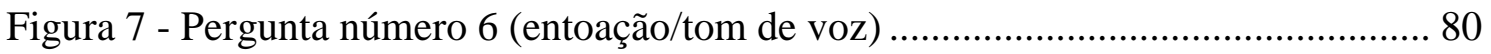

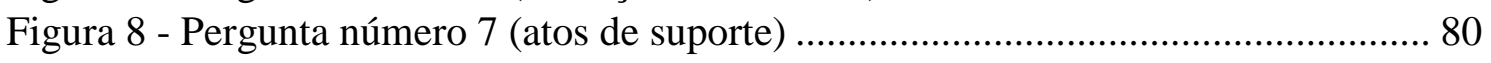

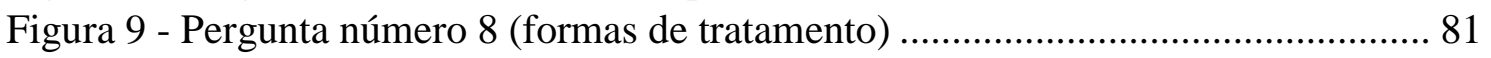

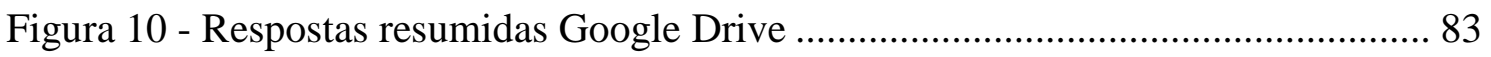

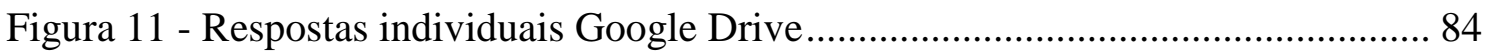

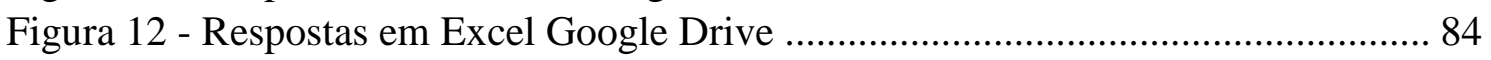

Figura 13 - Coluna/célula para comentário escrito opcional ...................................... 85 


\section{LISTA DE GRÁFICOS}

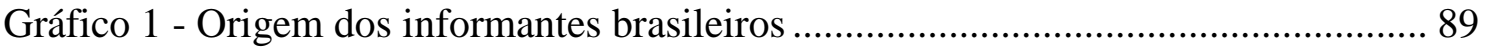

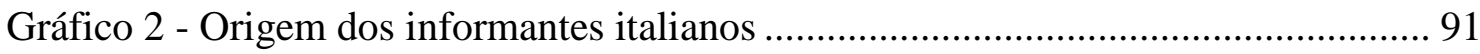

Gráfico 3 - Escolaridade dos informantes brasileiros................................................. 91

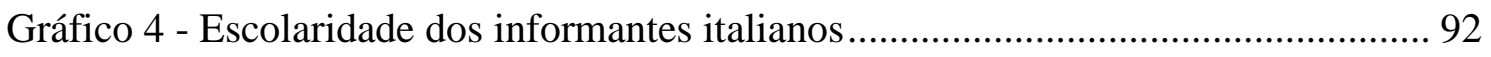




\section{LISTA DE TABELAS}

Tabela 1 - Prompts entregues aos participantes dos role-plays. 62

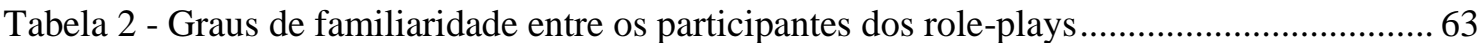

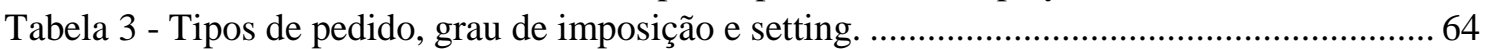

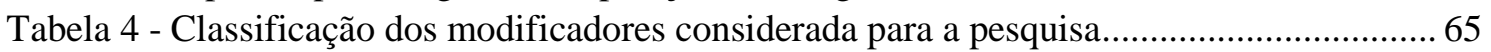

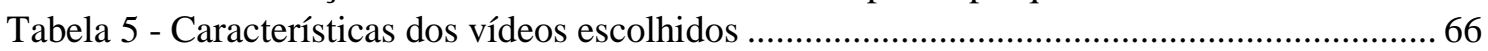

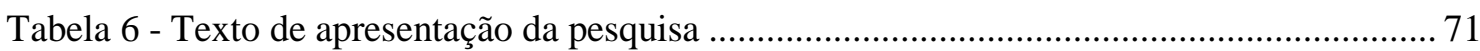

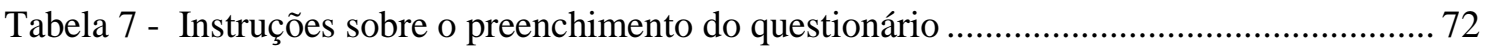

Tabela 8 - Detalhes das variáveis utilizadas para justificar o nível de cortesia............................. 76

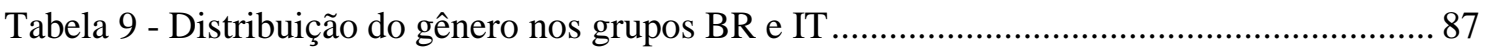

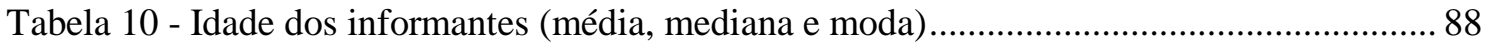

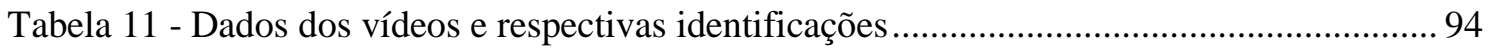

Tabela 12 - Níveis de cortesia atribuídos por BR e IT a todos os vídeos.................................... 95

Tabela 13 - Médias, DP e EP dos grupos BR e IT quanto aos níveis de cortesia ........................ 97

Tabela 14 - Diferença de médias dos grupos BR e IT quanto aos níveis de cortesia................... 99

Tabela 15 - Significância da diferença entre os grupos para a variável "cortesia" .................... 100

Tabela 16 - Vídeos que causaram percepções análogas e distintas nos grupos BR e IT............ 101

Tabela 17 - Resultados para o impacto das variáveis Q sobre a cortesia geral .......................... 103

Tabela 18 - Variáveis com correlação significante com os níveis de cortesia em geral ............ 105

Tabela 19 - Resultados para o impacto das variáveis Q sobre a cortesia - vídeo 1 ................... 106

Tabela 20 - Resultados para o impacto das variáveis Q sobre a cortesia - vídeo 2 .................. 107

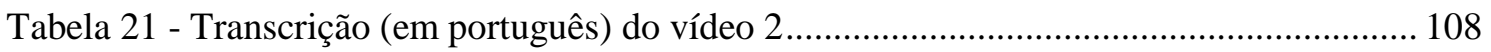

Tabela 22 - Resultados para o impacto das variáveis Q sobre a cortesia - vídeo 3 ................... 109

Tabela 23 - Resultados para o impacto das variáveis $Q$ sobre a cortesia - vídeo 4 .................. 110

Tabela 24 - Resultados para o impacto das variáveis Q sobre a cortesia - vídeos 5 e $6 \ldots \ldots \ldots \ldots . .112$

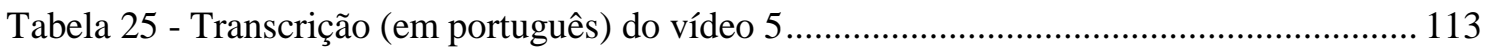

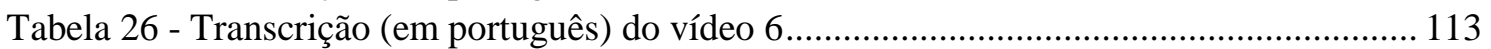

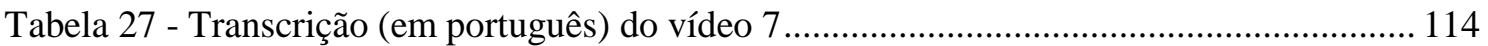

Tabela 28 - Resultados para o impacto das variáveis Q sobre a cortesia - vídeo 7 ................... 115

Tabela 29 - Resultados para o impacto das variáveis Q sobre a cortesia - vídeo 8 ................... 117

Tabela 30 - Variáveis com correlação significativa com os níveis de cortesia (por vídeo) ....... 118 


\section{LISTA DE SIGLAS E ABREVIATURAS}

ANOVA

BR

CCSARP

DCT

DP

EFL

EP

ESL

FTA

GI

GF

GL

IC

IT

L2

LE

MP

NELE

Sig

SLA

SPSS

UFC

UFES

UFPR

UFRGS

USP
Analysis of Variance

Grupo de brasileiros

Cross-Cultural Speech Act Realization Project

Discourse Completion Test

Desvio padrão

English as Foreign Language

Erro padrão

English as Second Language

Face Threatening Act

Grau de imposição

Grau de familiaridade

Graus de Liberdade

Iniciação científica

Grupo de italianos

Segunda língua

Língua Estrangeira

Model Person (pessoa modelo)

Núcleo de Ensino de Línguas em Extensão

Significância

Second Language Acquisition

Statistical Package for the Social Sciences

Universidade Federal do Ceará

Universidade Federal do Espírito Santo

Universidade Federal do Paraná

Universidade Federal do Rio Grande do Sul

Universidade de São Paulo 


\section{SUMÁRIO}

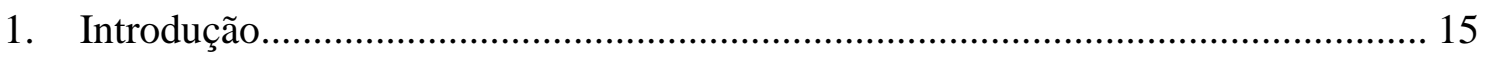

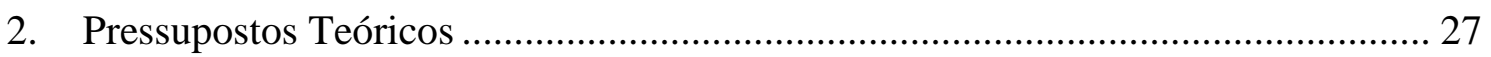

2.1 Da Pragmática linguística e dos estudos cross-culturais ................................ 27

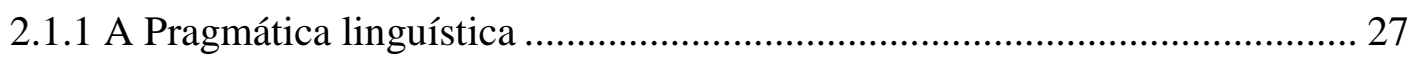

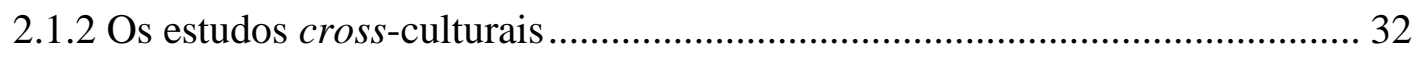

2.2 Da Teoria dos Atos de Fala e dos pedidos .................................................... 36

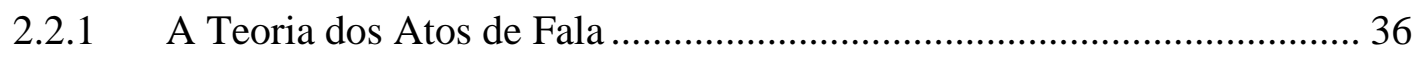

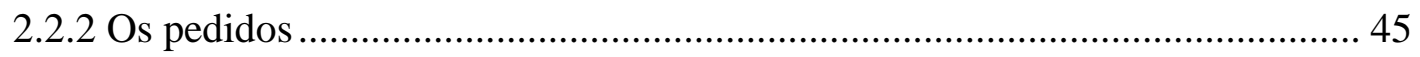

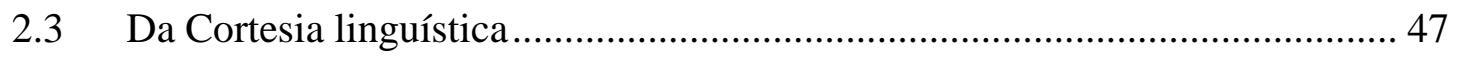

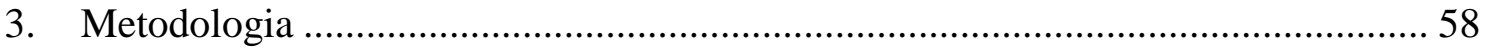

3.1 Caracterização da pesquisa: a metodologia mista........................................... 58

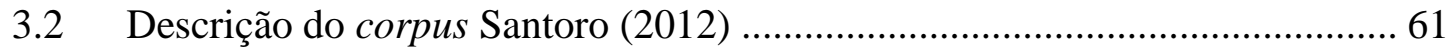

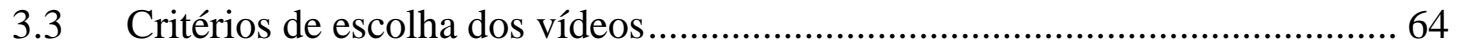

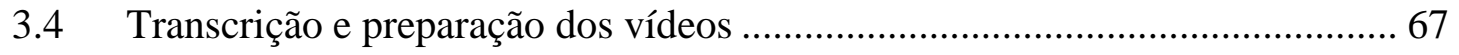

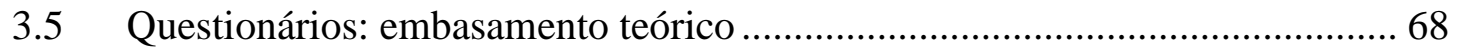

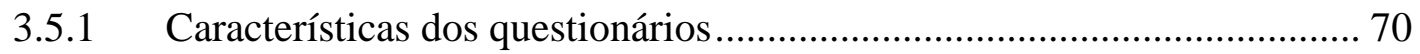

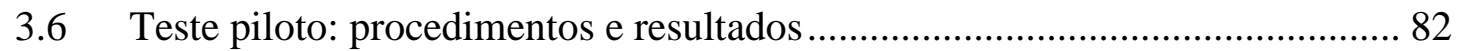

3.7 Tamanho da amostra, perfil dos informantes e coleta dos dados ..................... 85

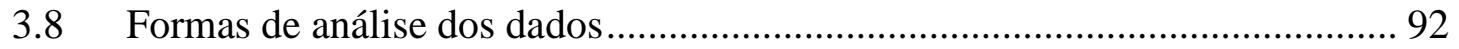

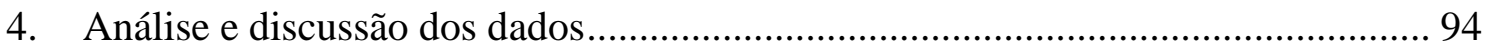

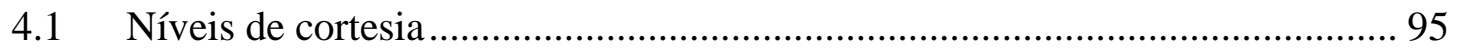

4.2 Impacto das variáveis Q sobre o nível de cortesia ....................................... 101

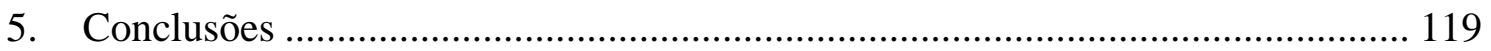

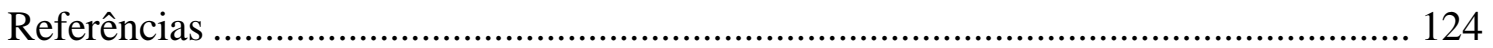

ANEXO I - NORMAS DE TRANSCRIÇÃO DOS VÍDEOS ................................... 130

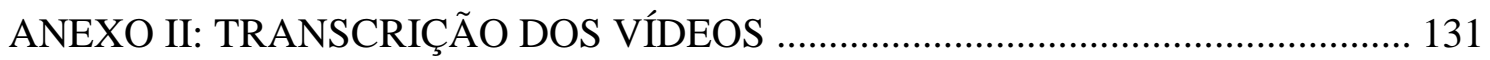




\section{Introdução}

Um aluno de um curso universitário de Letras que opta por estudar uma língua estrangeira ${ }^{1}$ se preocupa, no início, com o nível de dificuldade da língua que escolheu, com os percalços que encontrará por conta disso e até mesmo com a possibilidade de, por não ter se adaptado, escolher mudar seu percurso. Depois desse primeiro momento, quando o estudante começa a se sentir mais confortável com a escolha que fez e a ver que faz progressos no aprendizado da língua, essas preocupações perdem espaço para outras. Não se vê mais a língua como apenas gramática e normas e aumenta, em geral, a sensibilidade em relação aos registros, passando-se a observar semelhanças e diferenças entre a língua estudada e a materna. Assim, as questões ligadas à cultura da outra língua tornam-se cada vez mais importantes e, além disso, quando há algum contato com pessoas que nasceram e cresceram no país em que a língua estudada é habitualmente falada, é normal que se especule sobre o seu "jeito de falar" ou até sobre o seu "jeito de ser".

Fui aluna do curso de Letras da Universidade de São Paulo e escolhi a Habilitação em Língua e Literatura Italiana. Por ter tido, desde o primeiro semestre de estudo da língua, professoras falantes nativas ${ }^{2}$ de italiano, presenciei diversas situações de "desencontros" linguísticos ou culturais entre docentes e discentes e ouvi inúmeras histórias sobre malentendidos entre italianos em geral e aprendizes brasileiros de italiano. Os alunos, por desconhecerem que há normas pragmáticas distintas em diferentes culturas, tendem a esperar dos professores um "comportamento linguístico" mais próximo de sua cultura. Essa expectativa, que pode levar a uma má interpretação de comportamentos convencionalizados na

\footnotetext{
${ }^{1}$ Aproveitamos essa primeira ocorrência para esclarecer o que entenderemos por "língua" neste trabalho. Há uma longa discussão sobre quais elementos poderiam determinar os limites entre línguas específicas ou que nos fazem considerar um determinado sistema de comunicação efetivamente uma "língua", ou ainda sobre quais seriam as características universais das línguas naturais. Não está entre nossos objetivos discutir os limites que determinam onde termina uma língua e onde começa outra. Consideraremos, portanto, que falar de língua, o italiano e o português brasileiro, por exemplo, seja uma abstração baseada em alguns parâmetros, tais como a mútua compreensão entre indivíduos, bem como construtos de caráter educacional ou sociopolítico (cf. Verschueren, 2016).

${ }^{2} \mathrm{O}$ conceito de "falante nativo" e "não nativo" também precisa ser esclarecido, seguindo a mesma lógica utilizada na nota anterior para o conceito de língua. Trata-se, para nós, também de uma abstração, ainda mais necessária em um mundo em que línguas e culturas "viajam" e se misturam. Em princípio, consideraremos aqui falante nativo aquele que aprendeu uma determinada língua na família e na escola, enquanto falante não nativo será considerado aquele que aprendeu uma língua após sua "língua de família". É evidente que existem muitas situações que não permitem uma distinção nítida entre um caso e outro, como acontece, por exemplo, com falantes bilíngues ou crianças migrantes. No entanto, sem esse tipo de abstração não seria possível delimitar os objetos com os quais lidamos na pesquisa, o que inviabilizaria análises e comparações.
} 
língua/cultura alvo, remete-nos à noção que Jenny Thomas, em seu conhecido artigo de 1983, chamou de Cross-cultural pragmatic failure, "erro pragmático cross-cultural", isto é, a incapacidade de um indivíduo de entender o que significa aquilo que lhe foi dito ("what is meant by what is said", p. 91). A autora o subdivide em duas categorias: o erro pragmalinguístico, que consiste no uso ou na compreensão inadequada de certos elementos da língua, e o erro sociopragmático, "decorrente de percepções culturalmente diversas do que constitui um comportamento linguístico apropriado" (Thomas, 1983, p. 99).

Entre meus colegas era uma reclamação constante uma suposta atitude mais autoritária dos professores italianos em comparação àquela dos professores brasileiros. Hoje, depois de ter optado por realizar pesquisas na área da Pragmática, entendo que os traços que compunham essa postura eram tanto pragmalinguísticos - escolhas lexicais, uso de uma forma de tratamento mais formal, uso pouco frequente de modos de atenuar o que se diz etc. - quanto sociopragmáticos, como no caso do modo de organizar os cursos um tanto quanto hermético, em que aos alunos não era permitido dar sugestões ou solicitar pequenas mudanças de cronograma, por exemplo.

Considerando a distinção proposta por Thomas (1983), as reclamações dos alunos seriam, justamente, erros pragmalinguísticos e sociopragmáticos, que poderiam ter sido evitados se eles soubessem que um tratamento mais formal e uma relação mais verticalizada entre professores e alunos, que pode, entre outras coisas, influenciar as escolhas lexicais e levar ao uso pouco frequente de procedimentos de atenuação por parte dos professores, são normais na Itália.

Se de um lado temos os alunos que, baseados em suas próprias línguas e culturas, criam uma expectativa que os leva a cometer erros de julgamento, de outro temos os professores que, muitas vezes ignorando o fato de que a sala de aula é um ambiente em que se encontram duas línguas e duas culturas, não se preocupam com a importância de sensibilizar, desde o início, os estudantes quanto a essas questões. A propósito disso, Thomas (1983) afirma que "é um grande desserviço, mesmo para aqueles que estudam a língua alvo no país em que ela é falada, esperar que os aprendizes simplesmente 'absorvam' as normas pragmáticas, [...]” e Nuzzo e Rastelli (2009), falando do ensino de italiano como língua estrangeira, reforçam a importância de, já a partir das primeiras unidades didáticas, ensinar os fatores 
pragmalinguísticos e sociopragmáticos que regulam o uso adequado das formas de tratamento e dos procedimentos de mitigação, que são particularmente complexos.

Observar as interações entre italianos e aprendizes brasileiros, inclusive aquelas em que a brasileira aprendiz era eu, foi o que me motivou a tentar compreender melhor o que ocorre na relação entre falantes de diferentes línguas e culturas, especialmente de um ponto de vista linguístico. O processo de selecionar a perspectiva da qual partir para tentar entender essas relações passou por aprofundar a consciência de que, ao utilizar a linguagem em uma interação, são essenciais não apenas elementos linguísticos, mas também aqueles considerados contextuais $^{3}$, tais como fatores ligados ao ambiente, ao perfil social dos falantes de acordo com os grupos em que estão inseridos, ao conhecimento de mundo que compartilham (ou não), entre outros. A Pragmática, sendo a "ciência do uso linguístico, que estuda as condições que governam a utilização da linguagem" (Fiorin, 2007, p. 166), mostrou-se a perspectiva de análise ideal para realizar um estudo que, partindo de aspectos da língua em uso, pretende analisar a relação entre italianos e aprendizes brasileiros de italiano, gerando informações a partir das quais se possam, posteriormente, instruir aprendizes brasileiros de italiano sobre os aspectos pragmáticos dessa língua.

Para empreender uma pesquisa empírica dessa natureza, foi necessário selecionar um fenômeno relativamente circunscrito, por meio do qual pudéssemos obter dados de brasileiros e italianos comparáveis entre si. Para isso, recorremos a uma noção fundamental para a Pragmática, aquela de que, por meio da linguagem, é possível não apenas descrever o mundo, mas agir, como afirma Austin em How to do things with words (1962), obra considerada fundadora da Pragmática e em que foi introduzida a Teoria dos Atos de Fala. De acordo com esse quadro teórico, na categoria dos atos ilocucionários (ações realizadas por meio do dizer) estão os pedidos, que estão entre os atos de fala mais estudados pela Pragmática por serem considerados Face Threatening Acts - FTA, em tradução livre, atos ameaçadores de face.

\footnotetext{
${ }^{3} \mathrm{O}$ contexto é de tal maneira importante para os estudos em Pragmática (tendo também, ainda que não tratemos dele especificamente, ressonâncias naquele que aqui apresentamos), que essa área poderia ser descrita, conforme Bettoni (2006, p. 64), como "a teoria do contexto". Apesar de se tratar de um objeto difícil de delimitar, um modo relativamente conciso de fazê-lo foi proposto pela mesma Bettoni (2006), que fala na distinção contexto linguístico e contexto extralinguístico. $\mathrm{O}$ primeiro seria o fragmento de língua que precede o enunciado em questão e ajuda o falante a construí-lo e o ouvinte a compreendê-lo. O contexto extralinguístico, que também pode ser chamado de sociocultural, seria composto por tudo aquilo que incide sobre o significado do enunciado e pode ser subdividido em situação objetiva, da qual fazem parte o falante e o ouvinte com suas características de gênero, idade, religião, nível de instrução, papel ou distância social, etc., e rede subjetiva, que inclui o conjunto de crenças, desejos, objetivos, temores, preconceitos, posturas, conhecimento, etc.
} 
Foram Brown e Levinson (1987) a classificá-los dessa maneira, argumentando que eles ameaçam a face negativa do interlocutor (ou seja, a necessidade de ter seu território e liberdade de ação respeitados) ao "forçá-lo" a tomar uma decisão.

Lançar mão de estratégias para evitar a dita "perda da face" do interlocutor, mitigando o pedido (ou outros atos de fala), é parte do que se entende por Cortesia linguística ${ }^{4}$, de que trataremos de maneira mais aprofundada na seção 2.3, mas que pode ser definida sinteticamente como conjunto de "estruturas recorrentes na língua escrita e falada que manifestam um comportamento comunicativo cooperativo e respeitoso" (Mariottini, 2007, p. 9). É importante dizer que a ideia de que o uso dessas estratégias é apenas parte do fenômeno da cortesia vem da consciência de que ela não consiste em "um valor absoluto, mas envolve um grande número de nuances que podem, em parte, depender de avaliações subjetivas, mas estão fortemente relacionadas com as normas socialmente compartilhadas em uma determinada cultura" (Silva Neto e Santoro, 2015, p. 83). Além do modo em que o pedido é realizado, outro aspecto se mostra relevante: a percepção que o ouvinte tem da cortesia presente nesse ato de fala costuma ser decisiva para que se defina o modo em que ele vê o falante. Trazendo essa afirmação para a nossa realidade, o fato de um brasileiro perceber, por diversos motivos, como mais ou menos cortês um pedido realizado por um italiano o leva a construir uma imagem dele e, por extensão, dos italianos em geral, que pode ser avaliada de modo positivo ou negativo. Assim, após decidir que a Pragmática seria o viés da linguística mais apropriado para o que pretendíamos investigar, chegamos aos fenômenos específicos que seriam o foco de nossa pesquisa: os pedidos e a percepção da cortesia neles presente.

Sabemos que o caráter "ameaçador" do pedido que, em determinados contextos, “induz" ao uso de estratégias de cortesia e o repertório de que os falantes dispõem para modular

\footnotetext{
${ }^{4}$ Em português, na linguagem comum, é possível utilizar tanto cortesia quanto polidez para designar um comportamento civilizado, gentil e respeitoso. Entre os linguistas, ao menos no Brasil, a possibilidade de escolher entre dois termos parece fazer com que a opção por um ou outro não seja unânime. No entanto, se observarmos os textos em que são divulgados os resultados das pesquisas realizadas no âmbito do Projeto da Norma Urbana Culta das Principais Cidades Brasileiras (NURC), que conta com um núcleo de pesquisadores da Universidade de São Paulo - sede onde se desenvolveu o trabalho aqui apresentado, vemos que o termo utilizado é cortesia. De fato, um dos volumes publicados pelos participantes desse projeto é intitulado "Cortesia" e, em um dos artigos nele contidos, Villaça e Bentes (2008, p. 29) afirmam que a polidez teria como base um conjunto de normas sociais e seria mais relacionada ao que se chama de savoir fair, enquanto a cortesia seria "menos ritualmente determinada" e mais ligada à interação em si, que é objeto da análise linguística. Considerando a distinção que acabamos de expor e que em italiano, língua que estudamos em comparação com o português brasileiro, também se usa este termo, optamos, nesse trabalho, por utilizar cortesia e não polidez.
} 
sua força ilocucionária, variado tanto dentro de uma só língua quanto em línguas diversas, bem como o efeito que sua percepção pode causar em uma interação, motivaram inúmeros estudos em algumas subáreas da Pragmática. Uma delas é a Pragmática intercultural, cujo foco é a interação entre falantes de línguas diversas, que pode ocorrer na língua materna de um dos falantes, mas também em uma língua que é estrangeira para os dois. Independentemente do sistema linguístico utilizado por eles, uma interação desse tipo é sempre permeada por elementos das diferentes culturas envolvidas na interação.

A Pragmática interlinguística, por sua vez, estuda aspectos do ensino e da aprendizagem das normas pragmáticas de uma língua e cultura por parte de falantes não nativos. Bettoni (2006) aponta que muitos dos estudos interculturais são também interlinguísticos e vice-versa, mas há uma diferença de perspectiva entre as duas abordagens: enquanto a Pragmática intercultural observa o uso sincrônico dos fenômenos pragmáticos, isto é, os fenômenos que ocorrem no exato momento da interação, em que se dá o uso da língua, a Pragmática interlinguística se interessa pelo que ocorre nas várias etapas do processo de aprendizagem de uma língua e cultura estrangeira e, portanto, o viés é diacrônico. Outra vertente, e talvez aquela mais produtiva, é a Pragmática cross-cultural, que se dedica à análise de como fenômenos pragmáticos ocorrem em duas ou mais línguas e culturas, não necessariamente em contato.

Com base na distinção que acabamos de apresentar, uma pesquisa como a que decidimos desenvolver poderia ser considerada limítrofe por conter, de alguma maneira, elementos de pelo menos duas das três vertentes que descrevemos. Tendo informantes que são aprendizes brasileiros de italiano como língua estrangeira, com diversos níveis de conhecimento da língua/cultura alvo, a pesquisa poderia ser considerada interlinguística. Por outro lado, faz com ela seja considerada cross-cultural o fato de ter o intuito de comparar as percepções que tanto (aprendizes) brasileiros quanto italianos têm da cortesia presente em um mesmo de fala, o pedido. Dado que não observamos a realização de pedidos por aprendizes brasileiros ou, de um ponto de vista diacrônico, como adquiriram as competências necessárias para realizá-los de maneira eficiente, e considerando também que não os comparamos com pedidos realizados por falantes nativos de italiano, parece-nos mais proeminente o caráter crosscultural de nossa pesquisa. 
No âmbito da Pragmática cross-cultural, numerosos estudos analisaram as estratégias utilizadas em pedidos em diferentes línguas. São amplamente conhecidos aqueles realizados no contexto do projeto Cross-Cultural Speech Act Realization Project - CCSARP (Blum-Kulka; House; Kasper, 1989), que comparou pedidos e pedidos de desculpas, coletados por meio de Discourse Completion Tests (DCT's), em inglês (americano, australiano e britânico), dinamarquês, alemão, hebraico, russo e francês canadense. Um dos intuitos dos pesquisadores desse grupo era que os resultados de suas pesquisas não se limitassem à descrição, mas tivessem reflexos no campo do ensino e da aprendizagem de segundas línguas, área de estudos chamada Second Language Acquisition (SLA). O efeito esperado era que os aprendizes adquirissem maior consciência dos fatores pragmáticos envolvidos na realização de pedidos na língua que se dispuseram a estudar. São exemplos dos trabalhos do CCSARP aqueles de Weizman (1989), que investigou o uso de insinuações de pedidos (requestive hints) em inglês australiano, francês canadense e hebraico; de House (1989), que se concentrou em comparar com que frequência please e bitte (por favor, em inglês e alemão) eram utilizados por falantes nativos de alemão e inglês e aprendizes alemães de inglês, levando em consideração, entre outros aspectos, a variável gênero; e de Blum-Kulka e House (1989), cuja análise teve como foco identificar as estratégias utilizadas por falantes nativos de hebraico, francês canadense, espanhol argentino, alemão e inglês australiano, tentando também entender de que maneira fatores situacionais e culturais influenciavam a escolha das estratégias.

A percepção que nativos e não nativos têm da cortesia presente em pedidos em diferentes línguas também foi objeto de análise de alguns estudiosos. $\mathrm{O}$ texto mais antigo que resultou de nossa busca por trabalhos desse tipo, para entender de que modo são estruturados, foi o de Walters (1979). O estudo que ele conduziu contou com três grupos: um com 60 falantes nativos de inglês, outro com 75 estrangeiros (metade composta por coreanos e chineses e o restante de 17 línguas maternas diversas não especificadas) e o terceiro com dez falantes nativos de espanhol de Porto Rico. Um questionário em inglês foi ministrado aos dois primeiros grupos e, ao terceiro, uma versão em espanhol do mesmo questionário, com pedidos realizados com as mesmas 14 estratégias para a realização de pedidos, eliciadas por meio de um outro experimento feito com crianças de Porto Rico. A partir de pares de pedidos formulados de maneira diversa, os informantes deveriam indicar, partindo apenas do que estava escrito (ou seja, ignorando elementos contextuais), qual deles parecia mais cortês. Com base na análise dos dados coletados, Walters (1979) concluiu que os falantes nativos de inglês, tanto homens quanto mulheres, tiveram a mesma percepção (positiva ou negativa) das estratégias avaliadas, mas as 
mulheres apresentaram um maior grau de unanimidade do que os homens nas respostas e também maiores diferenças (quanto aos graus da escala de avaliação) entre formas mais e menos corteses. Os resultados relativos à comparação entre falantes nativos e não nativos de inglês, por sua vez, mostraram que havia uma alta correlação na percepção da cortesia das estratégias avaliadas. Além disso, descobriu-se que os falantes não-nativos tenderam a ser mais unânimes e a fazer maiores distinções entre formas mais ou menos corteses, assim como as mulheres no grupo dos falantes nativos. Os testes em espanhol, no entanto, apresentaram êxito diverso: não houve correlação significante entre as percepções relatadas por homens e mulheres.

Seguindo uma ordem cronológica, o segundo estudo que encontramos foi o de Carrel e Konneker (1981), realizado com um grupo de aprendizes de inglês como segunda língua (English as Second Language - ESL) composto de 73 adultos falantes de espanhol, japonês, farsi, árabe e outras línguas, além de um grupo de falantes nativos de inglês com 42 estudantes de graduação. Os informantes deveriam ranquear, da mais à menos cortês, oito diferentes estratégias de pedidos em inglês, com diversas propriedades semânticas e sintáticas, além de atribuir níveis de cortesia a eles a partir de uma escala de zero a cinco. Para isso, foram distribuídos conjuntos de nove cartas: uma com um contexto de compra em uma loja e outras oito com as estratégias de realização de pedido, baseadas na hierarquia básica de Lakoff (1973) e na sua ideia de que quanto maior a liberdade do interlocutor para negar o pedido, maior é a cortesia empregada para enunciá-lo. A análise dos dados indicou que as respostas de falantes nativos e de aprendizes de ESL correspondiam a uma hierarquia semelhante àquela pensada pelos pesquisadores e que a correlação entre a percepção da cortesia de nativos e não nativos era significante. No entanto, os não nativos, devido a uma hipersensibilidade aos fatores semânticos e sintáticos, foram menos unânimes quanto aos níveis de cortesia selecionados.

Matsuura (1998), por sua vez, empreendeu um estudo em que investigou a percepção que japoneses e americanos tinham da cortesia presente em onze diferentes maneiras de pedir uma caneta emprestada. Os 77 japoneses e 48 americanos deveriam avaliar os pedidos que lhes foram apresentados a partir de uma escala de 1 a 7 em que o nível 1 significava "mais desinibido" e o 7 "mais cuidadoso", isso porque uma oposição do tipo "descortês vs cortês" poderia causar problemas na tradução para o japonês. Em geral, japoneses e americanos atribuíram níveis de cortesia semelhantes às estratégias que lhes foram apresentadas, com exceção da interrogativa May I borrow a pen? (Pode me emprestar uma caneta?), vista por 
japoneses como neutra e por americanos como muito cortês. Além disso, nas situações em que o interlocutor era um amigo próximo, a interrogativa Could you borrow me a pen? (poderia me emprestar uma caneta?) foi tida por japoneses como pouco adequada, enquanto os americanos a consideraram apropriada ao contexto.

Um exemplo mais recente de pesquisa nesse sentido é aquele de Abdolrezapour e Eslami-Rasekh (2010), cujo objetivo era o de analisar a percepção que 35 aprendizes persas de ESL e 30 falantes nativos de inglês americano tinham da cortesia presente em pedidos em inglês. Os dados foram coletados por meio de um questionário com 18 pedidos em três diferentes situações e a cada informante foi solicitado avaliar, utilizando uma escala de 10 níveis, a cortesia neles presente. Ao contrário do que ocorreu nos estudos descritos até agora (Walters, 1979; Carrel e Konneker, 1981; Matsuura, 1998), a análise dos resultados indicou que há diferenças significativas entre as percepções dos dois grupos. Um fator importante para isso foi que o poder social (utilizando os termos dos pesquisadores) de quem realiza o pedido é percebido de maneira diversa pelas duas culturas. Outro aspecto a ser ressaltado é que, por outro lado, a distância social parece não influenciar a percepção da cortesia de iranianos e americanos.

Considerando o que vimos até agora, é possível notar que tanto entre os estudos que se interessam em identificar e comparar as estratégias utilizadas para realizar pedidos, quanto entre aqueles que comparam a percepção da cortesia presente nesse ato de fala, o inglês é uma língua muito recorrente. Estudos sobre essa língua vêm sendo realizados desde os anos 1980 e o fato de serem tão numerosos é explicável pelo status de língua internacional, adquirido especialmente a partir de 1945 (Trask, 2004, p. 168). Os estudos que envolvem a língua italiana, porém, conforme afirmam Nuzzo e Santoro (2017), começaram a ganhar espaço apenas mais recentemente. Nesse trabalho de 2017, as autoras apresentam um panorama - amplo, embora não pretenda ser exaustivo - dos trabalhos desenvolvidos no âmbito da Pragmática do italiano como segunda língua ou língua estrangeira a partir dos anos 2000. Ao longo do texto, é possível encontrar alguns casos em que o foco é a análise da realização de pedidos por falantes nativos de italiano e aprendizes. É o caso do trabalho do Grupo A.Ma.Dis (2008), em que, a partir da comparação de diálogos entre falantes nativos (que serviram como grupo controle), aprendizes espanhóis e duplas mistas (nativos e aprendizes) em que se realizavam pedidos, procurou-se verificar o modo em que utilizavam marcadores discursivos para atenuar a força ilocucionária do ato de fala em questão, com vistas a realizá-lo de maneira mais cortês. Nuzzo (2009) conduziu um estudo semelhante, analisando de que maneira aprendizes de italiano de três 
diferentes países africanos e da Índia (mas residentes na Itália) realizavam pedidos, comparando-os depois com pedidos realizados por informantes italianas, com o intuito de entender como utilizavam modificadores morfossintáticos e lexicais para mitigar a ameaça à face negativa dos interlocutores. Borreguero e Pernas (2009), por sua vez, investigaram de que maneira a gestão dos turnos, em diálogos entre aprendizes espanhóis de italiano e sua professora, falante nativa dessa língua, poderia funcionar como estratégia de cortesia ou descortesia.

Quanto a pesquisas cross-culturais que tenham como objeto de análise a percepção da cortesia presente neste tipo de ato de fala em italiano, por parte de falantes nativos e aprendizes, especialmente no eixo Brasil-Itália, a nossa busca não apresentou resultados. A ausência desse tipo de estudo impede que aspectos relevantes sobre a cortesia em italiano sejam incluídos no conteúdo programático de cursos de italiano como língua estrangeira para brasileiros, propiciando a ocorrência do que chamamos de erro pragmático na interlíngua de aprendizes de italiano LE. Segundo Blum-Kulka, House e Kasper (1989), estudos apontam que mesmo aprendizes de nível avançado cometem erros de natureza pragmática, tendo problemas para realizar determinados atos de fala ou compreender sua força ilocucionária ou cortesia, o que é resultado, acreditamos, da ausência de instruções nesse sentido.

Tendo em mente essa lacuna, foi idealizada a pesquisa de iniciação científica Cortesia em pedidos em língua italiana: a percepção de brasileiros e italianos, cujos resultados foram apresentados em Silva Neto e Santoro (2015), na qual procuramos identificar de que maneira a cortesia linguística em pedidos realizados por falante nativos de italiano era percebida por brasileiros e italianos, e o que poderia ter motivado possíveis disparidades nas percepções relatadas por brasileiros e italianos. Nessa pesquisa, 82 informantes divididos em (1) estudantes brasileiros de língua italiana no início dos estudos, (2) estudantes brasileiros de língua italiana em nível avançado, (3) italianos que vivem na Itália e (4) italianos que vivem no Brasil, foram consultados por meio de um questionário on-line. Cada informante avaliou oito pedidos, em áudio e vídeo, com base em uma escala de 1 a 5, justificando livremente, em seguida, o nível de cortesia atribuído a cada um deles. A partir da análise dos dados, foi possível verificar que:

i. todos os grupos apresentaram percepções análogas para a maioria dos vídeos; 
ii. alguns elementos foram mencionados de forma recorrente como justificativa para a escolha feita, fornecendo assim indícios de que poderiam ser tomados como categorias úteis para a organização da análise;

iii. não havia correlação entre os níveis de cortesia e as referidas categorias indicadas como justificativa;

iv. tanto brasileiros quanto italianos compartilham modos de interpretar alguns comportamentos linguísticos;

v. os italianos tendem a reforçar algumas interpretações por meio do contato com brasileiros.

Ainda que a pesquisa citada tenha sido bem-sucedida, pois os instrumentos utilizados foram eficientes para a coleta de dados e a análise deles permitiu responder adequadamente às perguntas de pesquisa propostas, é preciso considerar que, por ter se tratado de uma pesquisa com prazo de execução limitado (um ano), a análise ficou restrita aos objetivos iniciais e não foi possível abordar outros elementos ou aprofundar a análise dos primeiros resultados. Além disso, muito embora o número total de informantes tenha sido de 82 , cada subgrupo possuía aproximadamente 20 indivíduos, um número, portanto, relativamente limitado, a partir do qual pudemos apenas identificar as primeiras tendências, ficando ainda distantes da definição de padrões para a percepção da cortesia por parte de brasileiros e italianos. Entendemos que o trabalho anterior tenha sido de grande utilidade, funcionando como uma espécie de "pesquisa piloto". De fato, foram gerados resultados a partir dos quais poderiam ser realizadas outras investigações com o intuito de tentar entender melhor a percepção da cortesia por brasileiros e italianos.

Partindo dos resultados da pesquisa que acabamos de descrever, decidimos continuar investigando a cortesia em pedidos realizados por italianos, a fim de observar como é percebida por brasileiros e italianos, identificando o que pode motivar possíveis disparidades nos dois grupos de informantes. A fim de nortear a análise dos novos dados, definimos as seguintes questões:

1. quais analogias e diferenças podem ser identificadas entre os grupos de informantes quanto ao nível de cortesia atribuído aos pedidos? 
2. é possível reconhecer alguma correlação entre as diferentes categorias linguísticas e os níveis de cortesia?

Entre os objetivos da pesquisa incluímos, também, aprimorar o instrumento de coleta de dados, não porque não tenha sido eficiente, mas porque nos preocupamos em coletar dados com formato diverso em relação àqueles do questionário anterior, aperfeiçoando a maneira de consultar os informantes, especialmente no que diz respeito às justificativas, fazendo com que a experiência de contribuir com a pesquisa não criasse dificuldades desnecessárias aos informantes, que eles pudessem fornecer sua avaliação a partir de um número pré-definido de opções e que o levantamento e posterior análise dos dados fossem facilitados.

Apresentados, em linhas gerais, os objetivos e os parâmetros que nortearam nossa pesquisa, explicamos a seguir de que maneira organizamos a dissertação.

No capítulo "pressupostos teóricos", oferecemos um breve panorama das linhas teóricas que serviram de embasamento para nosso trabalho. Em sua primeira seção, "Da Pragmática linguística e dos estudos cross-culturais", recapitulamos as origens da Pragmática, falando das diversas áreas que contribuíram para que se consolidasse e poder assim tratar dos estudos cross-culturais, do período em que surgiram, de suas características, de seus principais expoentes e das possibilidades de aplicação. Na seção seguinte, "Da Teoria dos Atos de Fala", seguindo uma ordem cronológica, falamos da hipótese de Austin (1962), daquela de Searle (1969/1979) e, em seguida, do modelo de Sbisà (2009 [1989]). Por último, quanto à cortesia, descrevemos o modelo de Brown e Levinson (1987), mencionando depois algumas das críticas feitas a esse modelo e as propostas alternativas dele provenientes.

Iniciamos o capítulo sobre a "Metodologia" esclarecendo qual é a tipologia do estudo que realizamos, com base nas características das linhas de pesquisa mais frequentes no campo da SLA. Descrevemos, depois, o corpus a partir do qual escolhemos os vídeos que utilizamos na pesquisa, explicitando quais foram os critérios de seleção, quais são suas características e como os transcrevemos. Outro tema abordado nesse capítulo é o planejamento da coleta dos dados, desde a elaboração do questionário até a estimativa da quantidade de informantes a consultar e a coleta efetiva dos dados. Encerramos o capítulo sobre a metodologia com informações sobre a forma de análise dos dados. 
No capítulo "Análise e discussão dos dados", realizamos, como o próprio título sugere, a descrição dos dados coletados. Inicialmente, descrevemos os resultados relativos aos níveis de cortesia atribuídos aos pedidos presentes nos vídeos para, em seguida, comentar qual a correlação entre as variáveis utilizadas para justificar os níveis de cortesia e os níveis efetivamente atribuídos a cada vídeo.

Finalmente, na "Conclusão", retomamos os resultados da análise que realizamos para, então, responder às perguntas de pesquisa, definidas no início do trabalho. 


\section{Pressupostos Teóricos}

\subsection{Da Pragmática linguística e dos estudos cross-culturais}

Na primeira parte desta seção, com o objetivo de contextualizar nossa pesquisa, serão recapituladas as origens da Pragmática linguística, começando por uma rápida retomada das reflexões de Charles Morris, considerado o precursor da disciplina, até chegar aos aspectos mais frequentemente estudados pelos pesquisadores da área.

Em seguida, abordaremos os estudos ditos cross-culturais ou transculturais, que comparam duas ou mais línguas e culturas, assim como acontece no caso do nosso trabalho. Serão apresentadas, em linhas gerais, as motivações para o surgimento dessa subárea, algumas de suas vertentes e dois exemplos de projetos realizados nesse âmbito.

\subsubsection{A Pragmática linguística}

Antes que se tenha tido registro do uso do termo "Pragmática linguística" como o conhecemos hoje, surgiu, por volta dos anos 1870, o Pragmatismo, área da filosofia que teve como principais representantes Charles Peirce, William James e John Dewey. A chamada máxima pragmatista, "uma regra para esclarecer os conteúdos das hipóteses, rastreando suas 'consequências práticas"', foi muito relevante para essa corrente filosófica, isso porque Peirce e James, por exemplo, aplicavam-na frequentemente em seus trabalhos sobre o conceito de verdade (Hookway, 2016). Essa busca do Pragmatismo pelas consequências práticas das hipóteses acabou por deixar marcas no léxico comum, de modo que não raro há mal-entendidos entre linguistas e leigos: ao dizer que é um especialista em Pragmática (sem citar a linguística), um pesquisador pode ser confundido com alguém versado em como ser altamente objetivo e eficaz, isto é, "prático".

Por ter tido um papel central em seus trabalhos na área da Lógica e ter sido considerada um dos meios de provar a validade do Pragmatismo, a Teoria dos Signos ou Semiótica teve importância capital para Peirce, seu idealizador (Atkin, 2013). De acordo com essa teoria, todo signo é composto por três elementos interdependentes: um representamen (também chamado de signo), um objeto e um interpretante. Utilizando uma metáfora, Atkin (2013) afirma que podemos entender o representamen como uma palavra, uma frase, ou a 
fumaça como símbolo para a existência de fogo; o objeto como aquilo a que se refere à palavra ou frase, ou o próprio fogo; e o interpretante como o entendimento que temos da relação entre o representamen e o objeto.

Na esteira do modelo de Peirce, Charles W. Morris (1938) também defendeu que o signo tem uma estrutura tripartite, na qual interagem o veículo sígnico, o designatum e o interpretante. Para ele, a semiose, ou seja, o processo em que algo funciona como signo, poderia ser melhor entendida se considerássemos três diferentes dimensões: a semântica (relação entre veículos sígnicos e objetos), a sintaxe (relação entre diferentes veículos sígnicos) e a pragmática (relação entre veículos sígnicos e interpretantes). É consenso entre os estudiosos da área que, ao elaborar essa distinção no âmbito da Semiótica, foi Morris a inaugurar o uso do termo pragmática como hoje o aplicamos. Argumentando que a Pragmática seria uma das dimensões da Semiótica, Morris também propôs a distinção "pragmática pura" e "pragmática descritiva": a primeira teria como foco desenvolver uma metalinguagem por meio da qual se pudesse falar da dimensão pragmática da semiose, enquanto a segunda se interessaria por aplicar essa metalinguagem a casos específicos. A pesquisa aqui apresentada, por exemplo, segundo essa distinção, estaria no âmbito da pragmática descritiva, dado que utiliza uma metalinguagem já existente para descrever um determinado fenômeno.

Dizer que a Pragmática seria uma das dimensões da Semiótica, que trata da relação entre veículos sígnicos e interpretantes e que pode ser pura ou descritiva, no entanto, não é suficiente para nos fazer entender quais aspectos da linguagem humana ela efetivamente analisa. Morris, tentando explicitar quais seriam esses aspectos e reconhecendo que o termo "pragmática" remetia claramente ao Pragmatismo e aos modelos de Peirce, James e Dewey, chegou a uma formulação bastante abrangente, mas que cumpre o papel a que se dispôs:

Por "pragmática" se entende a ciência da relação dos signos com seus interpretantes. A "pragmática" deve diferenciar-se, portanto, do "pragmatismo" do mesmo modo em que o adjetivo "pragmático" deve diferenciar-se de "pragmatista". Dado que a maioria dos signos, se não todos, têm como interpretantes seres vivos, para caracterizar a pragmática com precisão seria necessário dizer que ela se ocupa de aspectos bióticos da semiose, isto é, de todos os fenômenos psicológicos, biológicos e sociológicos que integram o funcionamento dos signos. (Morris, 1938, p. 30) ${ }^{5}$

[By 'pragmatics' is designated the science of the relation of signs to their interpreters. 'Pragmatics' must then be distinguished from 'pragmatism', and 'pragmatical' from

\footnotetext{
${ }^{5}$ Exceto onde indicado, as traduções presentes nesta dissertação são de nossa autoria.
} 
'pragmatic'. Since most, if not all, signs have as their interpreters living organisms, it is a sufficiently accurate characterization of pragmatics to say that it deals with the biotic aspects of semiosis, that is, with all the psychological, biological, and sociological phenomena which occur in the functioning of signs.]

Conforme a Pragmática foi se estabelecendo como subárea autônoma da Linguística, outras formulações foram sendo propostas, mas isso não significa que quem se dedica a isso não encontre dificuldades. Escandell-Vidal (1996) afirma que o problema reside no fato de que ela é uma área de estudos relativamente nova e, por isso, assim como ocorre com outras áreas cujo estabelecimento é recente, é preciso descrevê-la e justificar a necessidade de criá-la. Outro aspecto que impõe obstáculos a essa tarefa é que, sob o rótulo de "Pragmática", há linhas de pesquisa bastante diversas entre si. Apesar disso, a pesquisadora defende que se pode dizer que a Pragmática é

[...] o estudo dos princípios que regulam o uso da linguagem na comunicação, isto é, tanto das condições que determinam o emprego de um enunciado concreto por parte de um falante concreto em uma situação comunicativa concreta, quanto da sua interpretação por parte do destinatário. (Escandell-Vidal, 1996, p. 13-14)

[...] el estudio de los principios que regulan el uso del lenguaje en la comunicación, es decir, las condiciones que determinan tanto el empleo de un enunciado concreto por parte de un hablante concreto en una situación comunicativa concreta, como su interpretación por parte del destinatario.

Levinson (2007 [1983]), naquele que foi um dos primeiros manuais sobre Pragmática $^{6}$, dedicou uma seção de mais de trinta páginas a um exame dos inúmeros aspectos que causam dificuldades ao se tentar criar uma definição precisa da área. Em um trecho dessa seção de seu livro, falando sobre o que chamou de "âmago do problema da definição", ele acaba por propor uma, ainda que indiretamente, dizendo que o ponto principal do problema da definição é que a Pragmática "abrange tanto aspectos da estrutura linguística dependentes do contexto, como princípios do uso e da compreensão linguística que não têm nenhuma ou têm muito pouca relação com a estrutura linguística" (p. 10). Desde a introdução a este trabalho até agora, essa é a quarta definição que citamos (em ordem de aparição: Fiorin, 2007; Morris, 1938;

\footnotetext{
${ }^{6}$ Citamos aqui a tradução brasileira, mas o referido manual foi publicado pela primeira vez em 1983 sob o título Pragmatics, pela Cambridge University Press.
} 
Escandell-Vidal, 1996 e Levinson, 2007 [1983]). Embora apresentem algumas disparidades entre si, em todas elas há uma referência mais ou menos direta ao estudo da relação entre o uso da língua/fatores linguísticos, os indivíduos que participam da interação e os elementos extralinguísticos das mais diversas naturezas, elementos esses que influenciam tanto o uso da língua quanto a interpretação do que é dito.

Voltando à definição de Pragmática dada por Morris em 1938, vemos que, segundo ele, seriam da alçada da Pragmática fenômenos psicológicos, biológicos e sociológicos da semiose, o que, como já dissemos, parece demasiado abrangente. Hoje, entretanto, é possível perceber que tal afirmação faz sentido, pois desde seu surgimento como uma das dimensões da Semiótica até o período em que começou a ser vista como área autônoma ${ }^{7}$, a Pragmática recebeu influências de diversas outras áreas do conhecimento e, de fato, investiga aspectos variados da comunicação. Entre essas áreas, segundo Bazzanella (2008), estão a Linguística, a Filosofia e a Sociologia. Da Linguística foram especialmente influentes o estruturalismo, cujo esforço primordial era o de sistematizar e generalizar aspectos das línguas; o funcionalismo, que atribuía maior relevância ao uso que à estrutura; e a gramática gerativa, para a qual, quando se trata de produção linguística, tem maior importância a competência e não necessariamente a execução. Do ramo da Filosofia, a contribuição mais significante veio da Filosofia da Linguagem, que (resumidamente) estuda a fundo a linguagem cotidiana para analisar, reformular ou resolver problemas filosóficos, e no âmbito da qual surgiu a Teoria dos Atos de Fala, de que trataremos em detalhes mais adiante. Finalmente, quanto à influência da Sociologia, foi indiscutivelmente importante a Sociolinguística, com seu foco nas variedades de uso e nos elementos contextuais, e da qual pode-se dizer que surgiu a Sociopragmática, definida por Leech (1983) como "a interface sociológica da Pragmática, que estuda de que maneira a performance pragmática está sujeita a condições sociais específicas”.

\footnotetext{
${ }^{7}$ Entre 1940 e 1970 a Pragmática foi vista apenas como um complemento à Sintaxe e à Semântica (Bazzanella, 2008), sendo considerada, para retomar a famosa expressão de Bar-Hillel (1971), a "lata de lixo da Linguística". Assim, seus limites não eram muito precisos e, mesmo para seus adeptos, ela parecia "um amontoado heterogêneo de dados, problemas e pontos de vista" (Dascal, 1979). A partir dos anos 1970, porém, houve um esforço por parte dos pesquisadores que se dedicavam à Pragmática no sentido de defini-la claramente e defender seu lugar no quadro da Linguística. Podemos citar como trabalhos importantes desse período aquele do próprio Bar-Hillel (1971), o de Stalnaker (1972) e o de Hansson (1974). No Brasil, vale mencionar um artigo de Marcelo Dascal, à época professor das universidades de Campinas e de Tel-Aviv, publicado em um periódico da Universidade Federal da Paraíba. Nesse trabalho, intitulado "O lugar da Pragmática na teoria da linguagem", o pesquisador, remontando às origens da área e mencionando outras tentativas de justificar a necessidade da existência da Pragmática, propõe-se a discutir a sua natureza, seus objetos de análise e algumas de suas possíveis abordagens.
} 
Todos os aspectos das áreas que acabamos citar, sejam eles metodológicos ou teóricos, enriqueceram e deram à Pragmática um caráter notavelmente multifacetado. Essa sua multiplicidade de perspectivas deu origem a uma característica pela qual é amplamente conhecida: a tendência à realização de estudos em interface. Em se tratando especificamente de Linguística, Horn e Ward (2008) afirmam que linguistas de diversas subáreas costumavam apropriar-se dos conceitos da Pragmática para simplificar a explicação dos fenômenos que estudavam e tal postura fazia parecer que se tratava de uma tentativa de evitar lidar com o fenômeno ao invés de explicá-lo adequadamente. Isso poderia levar-nos a crer que o que pensávamos ser um trunfo é, na realidade, um efeito negativo do caráter multifacetado da Pragmática. Contudo, os autores também afirmam que, com o passar do tempo, a compreensão do que essa área representa foi se aprofundando e, com isso, também o entendimento de como ela interage com outras faces da linguística. Assim, hoje são numerosos os trabalhos, como aqueles presentes no próprio volume organizado por Horn e Ward (2008), em que a Pragmática é abordada em interface com a Gramática gerativa, a Sintaxe, a Semântica, a Lexicologia, a Fonologia, a Aquisição da Linguagem e a Linguística computacional.

Passando de formulações gerais a um breve aceno sobre os aspectos do uso linguístico efetivamente analisados ou considerados pela Pragmática, se partirmos dos manuais sobre essa subárea da linguística que citamos até agora ${ }^{8}$, por exemplo, vemos que é uma constante o estudo da dêixis, entendida basicamente como o modo em que são codificadas na língua as referências a elementos contextuais como pessoa, tempo, lugar, características sociais ou discursivas; e da implicatura conversacional, mecanismo que permite ao falante fazer inferências sobre crenças, pensamentos e afirmações não explicitados por seu interlocutor e que é "regido" por máximas conversacionais (Bazzanella, 2008, p. 173). Especialmente importantes para o trabalho que desenvolvemos, no entanto, são os atos de fala, tema da seção 2.2.1 desta dissertação; a Cortesia linguística, da qual trataremos na seção 2.3, e também os aspectos sociais envolvidos na interação, que são também fundamentais para o modelo de cortesia de Brown e Levinson (1987), com seus conceitos de distância social e poder relativo.

\footnotetext{
${ }^{8}$ Levinson 2007 [1983]; Escandell-Vidal, 1996; Bazzanella, 2008; Horn e Ward, 2008.
} 


\subsubsection{Os estudos cross-culturais}

Para iniciar este que será um breve panorama sobre os estudos ditos cross-culturais, acreditamos que convenha fazer algumas observações de cunho terminológico. Dissemos na introdução que os estudos cross-culturais, no campo da Pragmática, são aqueles que se dedicam à comparação entre duas ou mais línguas e culturas. Conforme apontou Verschueren (2016), no entanto, muitas vezes o que se entende por Pragmática cross-cultural pode ser também rotulado de Pragmática contrastiva, o que fica bastante claro quando ele diz que esta se ocupa de "comparações sincrônicas entre dois ou mais sistemas linguísticos coexistentes" (p. 3). Para citar outras possibilidades de definição, Kraft e Geluykens (2007), utilizam Pragmática crosscultural como uma espécie de termo "guarda-chuva" para fenômenos tratados pela Pragmática contrastiva, intercultural e interlinguística; Schneider (2010), por sua vez, considera que a Pragmática contrastiva trata de aspectos pragmalinguísticos (produtos da interface entre a pragmática e a forma linguística) enquanto aquela cross-cultural se ocuparia de aspectos sociopragmáticos (produtos da interface entre pragmática e sociedade). Diante dessa multiplicidade de definições de estudos cross-culturais dentro do quadro da Pragmática, aquela que mantivemos presente durante toda a pesquisa foi justamente a que citamos no início desse trabalho, bastante sucinta, a partir da qual se depreende que o intuito principal dessa subárea é o de promover uma comparação entre elementos, sejam eles pragmalinguísticos ou sociopragmáticos, de duas ou mais línguas. Além disso, considerando o que disse Verschueren (2016), que acabamos de citar, e concordando com Bettoni (2006), segundo a qual são termos intercambiáveis Pragmática contrastiva, transcultural ou cross-Cultural, também nós consideramos esses termos como sinônimos.

Se a gênese da Pragmática remonta ao Pragmatismo, a Pragmática cross-cultural tem suas origens ligadas à Linguística contrastiva. De acordo com Verschueren (2016), em geral, os estudos dessa área não tratavam aspectos da língua em uso, fazendo apenas algumas referências a diferenças cross-linguísticas em termos de preferências de estilo. Apenas por volta dos anos 1980, começaram a ser publicados trabalhos em que era nítida uma abordagem que podemos identificar como pertencente à Pragmática contrastiva ou cross-cultural, isso por conta de um crescente interesse por uma abordagem pragmática em detrimento de um olhar fortemente voltado à estrutura. Wierzbicka (1991), porém, atribui o surgimento e difusão dos estudos cross-culturais a "uma reação a um universalismo equivocado" (p. 69), referindo-se especialmente aos modelos de Brown e Levinson (1987) e Leech (1983) (que serão abordados 
na seção 2.3) sobre os mecanismos implicados no fenômeno da cortesia. Seus princípios ou máximas, segundo a pesquisadora, pretendiam ser universais, mas são enviesados por uma perspectiva nitidamente anglocêntrica.

A despeito dos pormenores ligados à definição desse tipo de estudo e do que se acredita ter sido o motivo que o originou, é incontestável que o aspecto de maior importância para ele é a variação, que se deve à existência de diferentes sistemas linguísticos e de diferentes fatores culturais. Essa variação tem sido observada a partir dos pontos de vista mais diversos, como afirmou Verschueren (2016) em seu artigo intitulado Contrastive Pragmatics, no qual expôs as abordagens possíveis na área de que estamos tratando, algumas das quais mencionaremos aqui. Uma delas é a Análise Contrastiva do Discurso e da Conversação, que entende a língua como fenômeno social e instrumento dinâmico para a comunicação e considera também aspectos paralinguísticos, psicológicos e afetivos. Nesse viés, foi particularmente relevante o projeto denominado Pragmatics of Italian/English Cross-Cultural Interaction (PIXI), de Aston (1988) e Anderson et. Al. (1990). Um dos objetivos desse projeto era o de fornecer contribuições ao ensino das línguas, apresentando aos aprendizes diálogos que não fossem artificiais, previamente planejados. Por meio da análise de interações autênticas e eliciadas (que serviriam apenas para comparação), ocorridas em livrarias inglesas e italianas, descobriu-se que as identidades sociais dos participantes da interação não são simplesmente dadas a priori, mas são negociadas ou ratificadas ao longo do discurso. Seguindo essa lógica, o vendedor de uma livraria pode assumir, por exemplo, o papel daquele que aconselha o cliente. Também emergiu da investigação empreendida pelo projeto PIXI que esse processo de negociação de papéis sociais parece ser mais difícil para os falantes não-nativos da língua em que se deu a interação.

Ainda que haja várias outras abordagens, como a Retórica contrastiva e a Textologia contrastiva, parecem ser mais difusos os Estudos Contrastivos dos Atos de Fala, entre os quais poderia ser incluída também a pesquisa aqui apresentada, dado que investiga o pedido, ou a percepção que se tem dele, de um ponto de vista cross-cultural. Conforme dissemos na introdução (p. 34-36), a percepção que falantes nativos e não-nativos têm da cortesia presente nesse ato de fala, realizado em diversas línguas, foi estudada por Carrel e Konneker (1981), Matsuura (1998), Abdolrezapour e Eslami-Rasekh (2010) e Silva Neto e Santoro (2015). O modo como os pedidos são realizados (e não percebidos) por falantes nativos e não-nativos de italiano foi objeto dos trabalhos de Grupo A.Ma.Dis (2008), de Nuzzo (2009) e de Borreguero 
e Pernas (2009). Na linha dos Estudos Contrastivos dos Atos de Fala, teve um alcance considerável o trabalho realizado pelo CCSARP, idealizado inicialmente por Blum-Kulka e Olshtain (1984), mas que ganhou maior visibilidade com Blum-Kulka, House e Kasper (1989). Considerando o repertório linguístico empregado pelos informantes para realizar pedidos e pedidos de desculpas, o que seria algo típico de abordagens pragmalinguísticas, os pesquisadores que participaram desse projeto afirmam ter partido de uma perspectiva sociopragmática, preocupando-se em relacionar o modo em que a língua é utilizada para realizar os atos de fala que escolheram analisar com as variáveis sociais e situacionais que podem afetálos (Blum-Kulka, House e Kasper, 1989, p. 5). No âmbito desse projeto, pedidos e pedidos de desculpas realizados por falantes nativos e não-nativos foram analisados em inglês (australiano, americano e britânico), dinamarquês, alemão, hebraico, russo e francês canadense. Considerando cada uma das línguas estudadas, três eram os objetivos principais dos pesquisadores: i) estabelecer os padrões de realização, por falantes nativos, de pedidos e pedidos de desculpas em relação a diferentes parâmetros sociais (variabilidade situacional); ii) estabelecer diferenças e semelhanças no padrão de realização de pedidos e pedidos desculpas em termos linguísticos e em relação aos mesmos parâmetros sociais (variabilidade crosscultural); e iii) estabelecer as semelhanças e diferenças entre padrões de realização de pedidos e pedidos de desculpas por falantes nativos e não-nativos em relação aos mesmos parâmetros sociais (variabilidade individual e de falante nativo vs não-nativo) (Blum-Kulka e Olshtain, 1984, p. 197).

É importante notar que, embora o CCSARP tenha sido um projeto de referência para diversos pesquisadores, ele não foi imune a críticas. O aspecto mais veementemente criticado está ligado à metodologia de coleta dos dados: o uso de Discourse Completion Tests (DCTs) escritos. Nos questionários utilizados nesse projeto, os informantes deveriam completar diálogos, sempre precedidos de uma pequena contextualização, que representavam situações socialmente variadas. A crítica mais frequente a esse projeto foi ao fato de que as amostras linguísticas coletadas não seriam naturais, espontâneas. Apesar de se reconhecer que isso é extremamente difícil, inclusive por questões éticas e legais, considera-se que é sempre desejável ter dados realísticos, obtidos a partir de situações naturais e espontâneas. Essa busca por dados desse tipo, por conta da quase inevitável interferência do pesquisador, remete-nos ao chamado Paradoxo do Observador (Labov, 1972). Em resposta a essa crítica, além de citar a dificuldade de se obter esse tipo de dado, Blum-Kulka, House e Kasper (1989) ressaltaram que o modo em que estruturaram o DCTs, utilizando scripts baseados na língua falada, foi a maneira encontrada 
para resolver esse impasse e que utilizar um questionário desse tipo atendia à necessidade dos pesquisadores de coletar um grande número de dados de indivíduos de diversos países.

Com o intuito de identificar e comparar os elementos linguísticos utilizados na realização deste ato de fala, propôs-se também a estudar pedidos o grupo de pesquisa Pragmática (inter)linguística, intercultural e cross-cultural, com sede na Universidade de São Paulo (USP), que existe desde 2013, coordenado pelos professores Elisabetta Santoro, Luiz Antonio da Silva e Maria Zulma Moriondo Kulikowski, e conta com a colaboração de pesquisadores da Universidade Federal de Minas Gerais, da Universidade Aberta de Lisboa e da Università di Roma Tre, na Itália. Como é possível inferir a partir do próprio nome do grupo, seus membros realizam pesquisas em que são analisadas as características de uma só língua e cultura (Pragmática intracultural) que podem, depois, ser comparadas com outras (Pragmática cross-cultural); as interações entre falantes nativos e não-nativos (Pragmática intercultural) e aquelas em que o foco é o ensino e a aprendizagem de normas pragmáticas a aprendizes de uma língua estrangeira (Pragmática interlinguística). As línguas estudadas atualmente pelo grupo são o português brasileiro, o italiano, o espanhol (tuteante e voseante), além de alemão e português europeu.

Assim como ocorreu no projeto CCSARP, diante da dificuldade em coletar dados "naturalísticos", com gravações espontâneas que pudessem permitir captar fragmentos de diferentes realidades linguísticas, e tendo em vista a necessidade de construir um corpus amplo, foi necessário avaliar a viabilidade das metodologias de coletas de dados mais frequentes nesse tipo de pesquisa, considerando também como o formato do questionário influenciaria a validade externa (ou possibilidade de que os resultados sejam generalizados) ou interna (que permite ao pesquisador afirmar que seus resultados não são casuais) dos dados coletados ${ }^{9}$. Após diversas reuniões e discussões teórico-metodológicas, optou-se por utilizar um questionário dividido em suas seções: a primeira composta por um DCT escrito e aberto, em que os informantes deveriam escrever como realizariam um pedido com base em situações descritas pelos pesquisadores; a segunda composta por perguntas de múltipla escolha, em que os informantes deveriam escolher, entre uma série de possibilidades, o tipo de pedido que realizariam e considerariam adequado com base na situação descrita.

\footnotetext{
${ }^{9}$ Para mais informações sobre validade interna e externa de dados, bem como sobre diferentes metodologias de coleta de dados, ver Santoro (2012).
} 
O processo que levou à escolha do tipo de questionário adotado pelo grupo para a construção do corpus a ser analisado e os princípios que nortearam a elaboração das perguntas utilizadas foram expostos detalhadamente no capítulo Pragmática sociocultural: a elaboração de um corpus (Santoro, Kulikowski e Silva, 2017). Além disso, a partir de uma amostra de dados do português brasileiro e do italiano, realizou-se uma análise preliminar, cujos resultados foram expostos no artigo Richieste e attenuazione: un confronto tra italiano e portoghese brasiliano (Santoro, 2017). Vale ainda dizer que os membros do grupo Pragmática (inter)linguística, intercultural e cross-cultural, além de divulgarem em diversos eventos no Brasil e no exterior os resultados de suas pesquisas individuais e daquela realizada em conjunto, também organizaram três Jornadas de Estudos em Pragmática (JEP), ocorridas na USP em 2015, 2016 e 2017, para expor e discutir os trabalhos que vem sendo desenvolvidos pelos integrantes. No evento de 2017, cujo tema foi “Atos de Fala em Perspectiva Cross-Cultural”, também pesquisadores externos ao grupo puderam apresentar suas pesquisas.

\subsection{Da Teoria dos Atos de Fala e dos pedidos}

Tendo em mente o contexto da Pragmática linguística e dos estudos cross-culturais, no próximo item trataremos dos principais aspectos da chamada Teoria dos Atos de Fala, falando inicialmente do que propôs Austin, seu idealizador, para então tratar das contribuições de Searle e Sbisà a esse quadro teórico que motivou numerosos estudos. Em seguida, com base na teoria descrita, trataremos especificamente do ato de fala que nos interessa - o pedido explicitando seu lugar dentro desse modelo.

\subsubsection{A Teoria dos Atos de Fala}

Consciente das dificuldades que tanto gramáticos quanto filósofos da linguagem enfrentavam para distinguir perguntas ou ordens, por exemplo, de sentenças que parecem ter apenas a função de descrever um estado de coisas, John L. Austin propôs-se a discutir quais seriam exatamente as características dessas sentenças e de que modo seria possível distinguilas umas das outras com base, entre outros aspectos, nos meios linguísticos com os quais são realizadas ou na intenção de quem as pronuncia. Foi esse o tema abordado por Austin durante uma das edições das William James Lectures, realizada na Universidade de Harvard em 1955. 
O conteúdo das doze conferências por ele proferidas foi organizado e publicado postumamente em 1962 sob o título de How to do things with words.

Como sabemos, nessa obra está a ideia que fundamenta aquela que veio a ser chamada de Teoria dos Atos de Fala: falar é agir. Um dos exemplos a partir dos quais Austin (1962) desenvolveu essa hipótese foi o da cerimônia de batismo de um barco. A pessoa escolhida para realizar o referido ritual poderia proferir um enunciado do tipo "Eu nomeio esse barco Rainha Elisabete" e tão somente isso tornaria a embarcação devidamente batizada. O que Austin argumentou é que não se trata de descrever um ato ou um estado de coisas, mas, efetivamente, do cumprimento de uma ação. Assumindo isso como verdade, o filósofo chamou de performativos os enunciados que, no todo ou em parte, consistem na realização de um ato. Em oposição a eles, estariam os enunciados que servem para descrever, reportar ou constatar algo, os enunciados constatativos.

Entretanto, ao afirmar que um enunciado como aquele proferido por quem batiza um barco é, para todos os efeitos, uma ação, Austin defendeu que ele precisa cumprir alguns requisitos. Assim, em sua conferência de número II, ele elencou seis condições para que um performativo tenha sucesso, as "condições de felicidade" (Austin, 1962, p. 14-15). Como veremos a seguir, elas não são propriamente linguísticas, mas influenciam ou contextualizam, de alguma maneira, o enunciado. As condições de felicidade de um performativo, segundo Austin, são:

(A1): é necessário que exista um procedimento convencionalmente aceito, que tenha um efeito igualmente convencionalizado e que inclua o proferimento de certas palavras pelas pessoas certas;

(A2): as circunstâncias e pessoas precisam ser adequadas ao procedimento invocado;

(B1): o procedimento deve ser efetuado por todos os participantes de modo correto e (B2): completo;

(r1): nos casos em que o procedimento a ser invocado foi "projetado" para ser usado por pessoas com certos pensamentos ou sentimentos, a pessoa participando e invocando o procedimento deve ter esses pensamentos ou sentimentos, e os outros participantes devem ter a intenção de se conduzirem da maneira adequada; além disso;

(r2): devem realmente conduzir-se dessa maneira subsequentemente. 
As condições A1 e A2 remetem claramente a uma ideia de convenção, isto é, de que os performativos teriam uma espécie de roteiro a ser seguido, conhecido pelos falantes e demais participantes do ato, enquanto B1 e B2 diriam respeito à necessidade de que haja o cumprimento por completo de todas as partes do "roteiro", tanto por parte de quem realiza o ato, quanto por parte dos outros participantes. As duas últimas condições, no entanto, parecem ter mais a ver com a intencionalidade dos indivíduos: não basta conhecer o "roteiro" do performativo a ser proferido e cumprir as suas etapas, quem realiza e quem participa da ação como um todo precisa, efetivamente, aderir a ela.

Se considerarmos que, segundo o que vimos até agora, é possível agir por meio do dizer apenas com enunciados de um determinado tipo, então poderíamos afirmar que a hipótese da Teoria dos Atos de Fala seria "falar é agir, desde que se profira um performativo". Essa formulação poderia ser chamada, como alguns pesquisadores da área da Pragmática costumam dizer, de "Austin 1" ou "Austin antes da reformulação", isso porque, a partir da conferência VIII, reconhecendo que é uma tarefa pouco produtiva e muito complexa aquela de encontrar meios de diferenciar constatativos de performativos, o filósofo, de certo modo, passa a considerar que "dizer é sempre agir", e propõe uma nova classificação que subdivide cada enunciado em três dimensões:

1. Ato locucionário: ato de dizer, composto pelo som, pelo sentido e seu referente;

2. Ato ilocucionário: ação realizada por meio do dizer;

3. Ato perlocucionário: efeitos causados no interlocutor por meio do dizer.

Tendo abandonado a dicotomia performativos $v s$ constatativos em favor de uma classificação mais abrangente de atos de fala, Austin (1962) pôs-se a pesquisar os verbos usualmente empregados para proferir os atos ilocucionários, concentrando-se no que chamou de sua força ilocucionária, isto é, naquilo que se quer realizar por meio do dizer. Com base no resultado de sua investigação, Austin (1962, p. 150) classificou essas forças em cinco categorias de verbos:

- vereditivos: ligados à ideia de julgamento, de veredito. Eles, no entanto, nem sempre exprimem certeza, podendo também transmitir a ideia de estimativa, de cálculo ou de avaliação;

- exercitivos: remetem ao exercício de poder, direito ou influência; 
- comissivos: aqueles ligados ao ato de prometer, de comprometer-se a fazer algo, mas também ao ato de anunciar que se tem a intenção de fazer algo;

- comportativos: considerada por Austin a categoria mais problemática, está relacionada ao comportamento e aos rituais sociais;

- expositivos: ligados à expressão de opiniões ou argumentos.

As categorias que acabamos de ver foram propostas por Austin na última das conferências que realizou em Harvard. Ele próprio, logo após apresentar uma breve descrição de cada uma das categorias, afirmou que não pretendia que essa classificação fosse definitiva (Austin, 1962, p. 151) e, de fato, suas reflexões serviram de base para inúmeras discussões sobre a noção de agir por meio do dizer. Searle, aluno de Austin e conhecido por remodelar e difundir a Teoria dos Atos de Fala, toma a proposta de seu professor como ponto de partida e, com um olhar crítico e considerando uma série de critérios, formula a sua própria taxonomia. Um dos pressupostos do qual parte para realizar essa tarefa é considerar que um ato ilocucionário é composto por sua força ilocucionária, representada por $\mathrm{F}$, e seu conteúdo proposicional, representado por (p). Em uma sentença, com sua estrutura $F(p)$, a força ilocucionária corresponderia à ação cumprida ao proferi-la, enquanto seu conteúdo proposicional seria equivalente ao seu conteúdo. Desse modo, o enunciado "Está frio, não? ”, dirigido a uma pessoa que está próxima a uma janela aberta, tem como conteúdo proposicional um comentário sobre a percepção da temperatura do ambiente, mas, dependendo de fatores contextuais, pode ter a força ilocucionária de um pedido para que se feche a janela, ou ainda, por exemplo, de uma afirmação que serviria como aval para que alguém execute esse ato.

Outra noção importante para Searle (1979) é aquela de que se deve ter em mente a diferença entre verbos e atos ilocucionários. Atos ilocucionários podem, sim, ser realizados com verbos ilocucionários, mas não exclusivamente por meio deles. Essa, na verdade, é uma das críticas de Searle ao modelo de Austin, que fez um elenco daqueles que considerou os seis problemas primordiais do que foi discutido em How to do things with words. Em ordem crescente de importância, Searle afirma que: 6. há uma grande confusão entre verbos e atos; 5. nem todos os verbos listados por Austin são ilocucionários; 4. há muitas sobreposições entre as categorias; 3. entre elas há também muita heterogeneidade; 2. muitos dos verbos listados nas categorias não satisfazem a definição dada a elas; e, a mais importante de todas, 1. não há um princípio consistente que sirva de base para a classificação (Searle, 1979, p. 11-12). 
A propósito da necessidade de adotar princípios claros para criar uma taxonomia, Searle se baseia, principalmente, em três critérios ${ }^{10}$. O primeiro deles é o ponto ilocucionário, ou seja, a finalidade dos atos ilocucionários. É importante dizer que, conforme aponta o próprio Searle, "o ponto ilocucionário é parte e não sinônimo de força ilocucionária” (Searle, 1979, p. 3): utilizando o mesmo exemplo exposto pelo estudioso, pedidos e ordens possuem o mesmo ponto ilocucionário, isto é, constituem uma tentativa de fazer com que o ouvinte realize alguma ação; no entanto, a força ilocucionária desses dois atos de fala é diversa. A orientação de ajuste entre as palavras e as coisas é o segundo fator determinante para diferenciar um tipo de ato de outro. A orientação de que fala Searle (1979) tem dois sentidos possíveis: palavra-mundo, representado pelo símbolo $\downarrow$, em que as palavras se adequam a um estado de coisas, como em descrições ou explicações; e mundo-palavra, representado por $\uparrow$, em que um determinado estado de coisas se adequa às palavras, como em promessas ou ordens. O terceiro critério mais importante é o estado psicológico expresso, ou condição de sinceridade. Searle (1979) argumenta que, ao realizar um ato de fala com um conteúdo proposicional, todo falante exprime um determinado estado de espírito em relação a esse conteúdo. Nesse sentido, quem faz uma afirmação expressa crença (belief) no que está dizendo, quem promete tem a intenção de cumprir e quem dá uma ordem deseja ser atendido. Esses diferentes estados psicológicos são representados por suas iniciais maiúsculas em inglês. Assim, por exemplo, temos B (belief) para crença, I (intention) para intenção, D (desire) ou W (want) para desejo ou vontade e P (pleasure) para prazer.

Austin (1962), como vimos anteriormente, havia estabelecido condições de felicidade para que um ato performativo fosse bem-sucedido. Searle (1969), ao tratar do funcionamento da promessa, que considerou um ato altamente complexo, também sugeriu que há um conjunto de regras que precisam ser respeitadas para que um ato ilocucionário, em geral, também o seja. São elas:

- regra de conteúdo proposicional: ligada à necessidade de que exista um conteúdo proposicional construído de tal modo que explicite e viabilize a realização de um dado ato ilocucionário;

- regra preparatória: que remete às condições necessárias para que um ato se realize;

\footnotetext{
${ }^{10}$ Os critérios apresentados por Searle (1979) são doze, mas ele mesmo afirma que os três primeiros, que citamos aqui, parecem-lhe ser os mais importantes (p. 5): "These three dimensions - illocutionary point, direction of fit, and sincerity condition - seem to me the most important, and I will build most of my taxonomy around them, but there are several others that need remarking".
} 
- regra de sinceridade: segundo a qual o estado psicológico expresso pelo falante precisa ser adequado ao ato em questão;

- regra essencial: relativa à necessidade de que o falante tenha realmente a intenção de que o enunciado que profere tenha o valor do ato de fala de um determinado tipo (no caso de uma pergunta, por exemplo, essa regra consiste em que o falante queira obter alguma informação de seu ouvinte).

Aplicados os critérios e pressupostos que havia definido, Searle chegou à seguinte classificação de atos ilocucionários:

- assertivos: incluem a maior parte dos vereditivos de Austin. Segundo Searle, por meio de atos assertivos dizemos como determinadas coisas são. Nessa categoria estão os atos de afirmar, sugerir, insistir, concluir, deduzir, "orgulharse", lamentar-se;

- diretivos: para Searle, muitos dos atos exercitivos de Austin estariam nessa categoria. Um ato diretivo consiste em uma tentativa de fazer com que o outro faça algo. Os verbos usualmente empregados para realizar esses atos são pedir, ordenar, suplicar, aconselhar, desafiar, convidar;

- comissivos: correspondentes em nome e em função aos comissivos de Austin, expressam sentimentos e o intuito de comprometer-se a fazer algo e são realizados com os verbos prometer, jurar, oferecer, apostar;

- expressivos: assemelham-se aos comportativos de Austin e também têm como fator importante a questão do comportamento ou do sentimento. Os verbos utilizados para realizar esse tipo de ato podem ser felicitar, desculpar-se, lamentar-se, perdoar, elogiar, saudar e agradecer;

- declarativos: corresponderiam à categoria proposta pelo que chamamos anteriormente de "Austin 1", os performativos, e são realizados com verbos como batizar, casar, nomear, condenar.

Ao apresentar as categorias propostas por Searle, nós emulamos o modo em que ele próprio o fez, retomando aquelas inicialmente pensadas por Austin. Talvez essa constante (e devida) referência às reflexões austinianas e o fato de ter sido aluno do filósofo tenham feito com que seu trabalho não apenas fosse visto como uma espécie de continuidade natural da 
proposta daquele que é considerado o pai da Teoria dos Atos de Fala, mas como a leitura mais legítima e aceita dessa teoria. Rajagopalan (2010), no entanto, argumenta que Austin e Searle tinham maneiras de pensar muito diversas e que por isso mesmo, na realidade, o pensamento de Austin, nas mãos de Searle, teria se tornado algo irreconhecível, o que estranhamente passou despercebido por muitos estudiosos (p.17). Não temos aqui o intuito de discutir em que se baseia Rajagopalan (2010) para fazer tal afirmação, mas recorremos a ele para dizer que, além de Searle, muitos outros estudiosos realizaram tentativas no sentido de construir uma taxonomia dos atos de fala. Entre eles está a estudiosa italiana Marina Sbisà, cuja proposta é apontada por Rajagopalan (2010, p. 55) como aquela que buscou o meio termo entre uma visão dos atos de fala completamente empírica, sempre dependente de especificidades culturais ou individuais e que abre mão de qualquer esforço classificatório, e uma visão tradicionalista, que visa a uma taxonomia fixa e que acaba por não dar conta do que se dispõe a classificar, dada a complexidade do fenômeno.

Bazzanella (2008) observou que o modelo pensado por Sbisà (2009 [1989]) foi a proposta mais fiel àquela de Austin (1962), e com efeito, veremos a seguir que a estudiosa retoma diversos aspectos considerados pelo filósofo britânico. É interessante notar, porém, que ela vê a noção de ato de fala desenvolvida por Austin como um modo válido de iniciar uma reflexão sobre o funcionamento da linguagem, mesmo que talvez abstrato e com "fetiches" filosóficos, mas entende que sua classificação não seria uma verdadeira classificação. Sbisà (2009 [1989]) alega que o fato de Austin dizer que pode haver sobreposição de classes e de dedicar uma grande parte de sua discussão a esses casos sugere que sua classificação, na realidade, seria uma espécie de mecanismo descritivo e gerador de híbridos, o que seria também algo muito próximo do intuito de seu próprio trabalho.

Um dos principais critérios utilizados para propor uma "nova" tipologia de atos de fala é a noção de efeito, que já estava presente em Austin (1962), quando falava de perlocução. Assim, segundo Sbisà (2009 [1989]), pode-se dizer que um ato de fala é realizado não com base no uso de uma forma linguística específica, mas com base no fato de o uso dessa forma surtir um determinado efeito, mutuamente reconhecido e reconhecível (p. 70). Outro aspecto presente em Austin (1962) e retomado pela estudiosa italiana é a bilateralidade do performativo. Segundo essa ideia, se não houver acordo por parte do interlocutor, o ato de fala não se completa e o efeito esperado não se realiza. Por extensão, Sbisà (2009 [1989]) considera que um ato ilocucionário não é realizado completamente se não for obtido um mínimo efeito de recepção. 
As condições de felicidade de Austin (1962) também são retomadas por Sbisà, ainda que parcialmente. Para ela, essas condições atuam como requisitos intersubjetivos que os interlocutores consideram em seu trabalho de compreensão - interpretação do ato ilocucionários e, por isso, delas também depende o sucesso de um ato de fala (Sbisà, 2009 [1989], p. 81). As condições consideradas por ela são A2 (retomando as etiquetas utilizadas por Austin), segundo a qual as circunstâncias e pessoas precisam ser adequadas ao procedimento invocado; r1, que diz respeito à necessidade de que o estado de espírito e as crenças de quem realiza e participa do ato sejam adequados; e r2, que se refere a um comportamento sucessivo apropriado de quem participa do ato sucessivamente a ele. A escolha dessas e não das outras se justifica pelo fato de, segundo a pesquisadora, A1 ser muito abrangente e B1 e B2 terem a ver com os meios utilizados para realizar o ato, o que não condiz com um modelo que, como vimos, pretende priorizar o efeito do ato ilocucionário e não as formas utilizadas para realizá-lo.

A criação da tipologia de atos de fala que estamos descrevendo baseou-se na combinação das condições de felicidade aos efeitos de determinados atos ilocucionários. Contudo, além dos dois aspectos que acabamos de citar, também o conceito de competência modal é parte da "fórmula" utilizada para a elaboração desse modelo. Nos estudos em Semiótica narrativa, área em que o termo teve origem, um sujeito agente o é porque a ele cabem uma série de predicados modais pressupostos pelo seu ato e que podem ser estabelecidos e modificados por ação do próprio agente ou por iniciativa de outrem, por atos anteriores ou sucessivos (p. 75). As modalidades consideradas por Sbisà (2009 [1989]) são poder (ser capaz de) e dever (ter obrigação de), ambas deônticas, e saber, que remete à noção de convencionalidade e pode ser atribuída por reconhecimento intersubjetivo e utilizada para dar conta de aspectos epistêmicos dos efeitos ilocucionários (p. 76-7).

Além do que já mencionamos até aqui, conforme observou Bazzanella (2009), o modelo pensado por Sbisà também abordou a influência exercida pelo contexto sobre os atos de fala e a complexidade dos indicadores de força ilocucionária, uma característica muito presente nas pesquisas em interface entre a Pragmática e a Filosofia da Linguagem após as primeiras formulações da Teoria dos Atos de Fala. Quanto ao contexto, Sbisà (2009 [1989], p. 41-2) distingue contexto como dado externo, anterior ao ato de fala, de contexto pressuposto, que é sugerido, comunicado ou construído pelo próprio ato de fala em questão. É também importante para a estudiosa a distinção entre contexto de fato, constituído por circunstâncias materiais (físicas ou psicológicas), e contexto de direito, do qual fazem parte aspectos convencionalizados referentes às relações sociais ou institucionais. No que diz respeito aos 
indicadores de força ilocucionária, Sbisà (2009 [1989], p. 100) afirma que o seu principal interesse é investigar de que maneira alguns dos indicadores mais comuns (frases interrogativas ou imperativas, verbos modais, elementos lexicais específicos etc.) se relacionam com determinados tipos de atos ilocucionários e também como motivam determinados efeitos.

A partir dos princípios que acabamos de expor, Sbisà (2009 [1989]) propôs uma tipologia composta por quatro categorias, que retomam em grande parte aquelas pensadas por Austin (1962) ${ }^{11}$ :

- Exercitivos: atos em que um falante, dotado de poder, atribui e/ou elimina a deveres a seu/s destinatários;

- Comissivos: atos em que um falante, dotado de poder, atribui um poder a um destinatário 1 (um interlocutor) e um dever a um destinatário 2 (o próprio falante, que projeta para si mesmo um compromisso futuro, como ocorre em promessas);

- Vereditivos: atos em que um falante, dotado de poder, atribui um saber a um destinatário 1 e um dever (relacionado a esse saber) a um destinatário 2 (que pode ser o próprio falante ou um terceiro, a quem caberia, por exemplo, dar provas sobre o que foi dito);

- Comportativos: atos em que um falante, com base em um dever (ou necessidade) que lhe cabe, atribui um saber a um destinatário 1 e, ao mesmo tempo, um poder a um destinatário 2.

Se por um lado Sbisà (2009 [1989]) retoma muitos aspectos presentes nas reflexões de Austin (1962), por outro, ela também notou, como Searle e outros pesquisadores, que sua classificação se baseava fortemente na pesquisa e na análise de verbos performativos, de modo a parecer ter se estabelecido uma relação biunívoca entre um conjunto de verbos performativos e tipos possíveis de atos ilocucionários. Quanto a isso, ela se distancia claramente do filósofo britânico, dizendo que não tem a intenção de "bloquear a variedade de ações que a linguagem pode realizar à capacidade lexical de uma só língua” (p. 70), apesar de admitir o fato de um elenco de verbos performativos de uma língua poder fornecer uma gama intuitiva (mas não exaustiva e nem necessariamente hierarquizada) de forças ilocucionárias.

\footnotetext{
${ }^{11}$ A exceção é a categoria dos atos ditos expositivos.
} 
Feitas algumas considerações sobre a Teoria dos Atos de Fala, desde a sua idealização por Austin, passando pela leitura de Searle até a formulação de Sbisà, que não é desconectada das anteriores, mas incorpora elementos de outras áreas, como a Semiótica narrativa e da análise da conversação, trataremos em detalhes do ato de fala que nos interessa, o pedido.

\subsubsection{Os pedidos}

Segundo Blum-Kulka, House e Kasper (1989), “pedidos são atos que precedem eventos, expressando a expectativa do falante de que o ouvinte realize uma ação, seja ela verbal ou não verbal" ${ }^{\prime 2}$. Pode-se dizer que o cerne dessa afirmação é a ideia de que é possível agir por meio do falar - uma clara referência à Teoria dos Atos de Fala - e de que essa ação pode ter consequências concretas ou no campo do discurso. Além disso, é possível identificar uma espécie de tríade de elementos implicados na realização do pedido: um $e u$, a sua necessidade de obter algo e um indivíduo que pode, eventualmente, ajudá-lo a obter aquilo de que necessita. Por meio de uma análise bastante informal da dinâmica desse ato de fala, percebemos que o eu que se vê na situação de realizar um pedido chegou à conclusão de que precisaria fazê-lo considerando uma série de fatores, como a ausência de meios para executar alguma ação ou a impossibilidade de cumpri-la sozinho, por exemplo. Ciente daquilo de que precisa, esse $e u$ identifica alguém que o possa auxiliar e, com base nas características dessa pessoa, na urgência, na dificuldade implicada em realizar o que deseja obter e nas possíveis consequências que ele poderia acarretar, elabora mentalmente e, por fim, realiza o pedido. Vejamos agora como esse ato de fala foi descrito e classificado de um ponto de vista teórico.

No modelo de Austin (1962), muito embora "pedir" não seja mencionado na lista relativamente extensa de verbos desta categoria, esse ato de fala tem as características de um exercitivo, que, como vimos na seção anterior, tem a ver com o exercício de poder ou influência, com a possibilidade de mudar o curso de determinadas ações. Algo que nos permite identificar o pedido como um exercitivo é o fato de ele ter como consequência (ou efeito) que outros sejam levados ou autorizados a agir de uma dada maneira.

\footnotetext{
12 "Requests are pre-event acts: they express the speaker's expectation of the hearer with regards to prospective action, verbal or nonverbal" (Blum-Kulka, House e Kasper, 1989, p.11).
} 
Searle (1979), por sua vez, inclui o pedido entre os atos diretivos. Retomando os critérios utilizados por ele para definir os tipos de ato de fala, um pedido tem como ponto ilocucionário a tentativa de um falante de fazer com que seu ouvinte realize uma ação; a orientação de ajuste entre as palavras e as coisas é mundo-palavras: um determinado estado de coisas deve mudar subsequentemente à realização do ato; e o estado psicológico expresso (ou condição de sinceridade) é querer (W, do inglês want). Desse modo, um pedido tem a seguinte representação:

\section{$! \uparrow W(\mathrm{H}$ faça $\mathrm{A})$,}

em que o ponto de exclamação indica que se trata de um ato diretivo, W representa a condição de sinceridade, H o ouvinte (inicial do inglês hearer) e A a ação.

Finalmente, para Sbisà, o pedido é um ato comportativo que, se realizado de maneira adequada às características tanto do falante quanto do ouvinte, com as intenções corretas por parte de ambos e um comportamento subsequente adequado do ouvinte, tem como efeito previsto aquele de que o falante obtenha algo de que necessita. É oportuno observar que a decisão de Sbisà em considerar o pedido um ato comportativo e não exercitivo ou diretivo, como Austin e Searle, pode ser explicada se pensarmos na questão da competência modal. Enquanto para Austin (1962) e Searle (1979) um falante, dotado de poder, atribui um dever a um ouvinte, de maneira mais ou menos contundente, para Sbisà (2009 [1989]) o falante, ao realizar um pedido, é dotado não de poder, mas de dever. Assim, o fato de esse falante atribuir um saber a um destinatário e um poder a outro constitui não um exercício de poder, mas uma reação a uma necessidade ou desejo.

Pensando no ponto de vista daquele que ouve um pedido, diante do que lhe foi solicitado, esse indivíduo avalia se quer e tem condições de ajudar, o esforço a ser feito para isso, se sua iniciativa poderia gerar consequências desagradáveis, entre outros aspectos. Brown \& Levinson (1987), a propósito da preocupação do falante em prever os possíveis efeitos de seu pedido e de toda a análise que o interlocutor precisa fazer diante dele, afirmam que o pedido é um Face Threatening Act (FTA): ato que ameaça a liberdade de ação do interlocutor (ou sua face negativa) e, por isso, exige do falante a utilização de meios para mitigá-lo. Na seção a seguir, trataremos em detalhes dessa perspectiva. 


\subsection{Da Cortesia linguística}

Sabemos que a bibliografia dedicada aos estudos sobre a Cortesia linguística construída até hoje é bastante expressiva, e pode-se dizer que o interesse em estudá-la começou a ganhar força especialmente a partir anos 1960. De acordo com Terkourafi (2005, p. 238-9), a Filosofia da Linguagem de Grice e Searle foi diretamente ligada ao início de uma teorização da Cortesia linguística. Grice (1989 [1967]), a propósito do Princípio de Cooperação, admitiu que, além das máximas conversacionais da Quantidade, Qualidade, da Relação e do Modo, há diversas outras observadas pelos participantes de uma interação, entre elas a da cortesia ${ }^{13}$. Searle (1979), por sua vez, tratando de atos de fala indiretos, defende que sua principal (embora não a única) motivação seja esse aspecto do uso linguístico ${ }^{14}$.

Robin Lakoff contribuiu com essa discussão (à época ainda recente) por meio de seu famoso artigo The logic of politeness; or, minding your $P^{\prime} s$ and $Q^{\prime} s$, Nesse texto, Lakoff (1973) argumenta que, durante uma interação, os falantes lidam com três diferentes áreas do conhecimento pragmático: a relação que tem com seu ouvinte, sua situação no mundo real no momento da enunciação e o quanto deseja mudar uma ou ambas as condições que acabamos de ver. Para isso, eles levariam em consideração regras que com frequência entram em conflito, apesar de muitas vezes terem efeitos coincidentes e se reforçarem mutuamente. Essas regras foram chamadas por Lakoff (1973) de Máximas da Competência Pragmática, que são "seja claro" e "seja cortês". Para a estudiosa, em algumas situações, ser claro corresponde a ser cortês, mas quando há conflito é preciso escolher e, em geral, nessas ocasiões, a máxima da cortesia parece ser a que tem prioridade. Agir segundo essa máxima significa não importunar, oferecer alternativas e fazer com que o outro se sinta bem (ou comportar-se amigavelmente).

Tanto para planejar alguns elementos da metodologia empregada na pesquisa, quanto para embasar a análise dos dados que coletamos, partimos, como na pesquisa que realizamos anteriormente, de Brown e Levinson (1987). De fato, o modelo por eles proposto foi o centro de muitas polêmicas por pretender encontrar aspectos universais da cortesia e por, segundo os críticos, apresentar características muito ligadas às culturas ocidentais ou, mais

\footnotetext{
13 "There are, of course, all sorts of other maxims (aesthetic, social, or moral in character), such as "Be polite", that are also normally observed by participants in talk exchanges and these may also generate nonconventional implicatures (Grice, 1989 [1967], p. 28).

14 “The chief motivation - though not the only motivation - for using these indirect forms is politeness" (Searle, 1979, p. 48).
} 
especificamente, anglófonas. Com base em nosso trabalho anterior, porém, acreditamos que para uma pesquisa como a nossa, realizada justamente em âmbito ocidental, as críticas feitas a esse modelo nesse sentido não se aplicam. De qualquer maneira, consideramos importante mencionar outros modelos pensados para descrever o fenômeno da Cortesia linguística. Sendo assim, nesta seção, descreveremos os principais aspectos da proposta de Brown e Levinson (1978), mencionando em seguida algumas das críticas a ela dirigidas.

Partindo do pressuposto de que os padrões utilizados na construção do discurso são a matéria-prima das relações sociais, Brown e Levinson, por meio da análise de registros de língua falada em inglês (americano e britânico), tzeltal (língua maia falada no México) e tâmil (língua falada no sul da Índia), procuraram elaborar um modelo formal que desse conta das semelhanças cross-culturais quanto à "codificação" da cortesia. Contudo, o intuito era que esse modelo pudesse também servir como referência para descrever usos culturalmente específicos. O resultado dessa iniciativa foi publicado originalmente em forma de artigo em 1978 e, depois de uma série de aprofundamentos, no livro intitulado Politeness: some universals in language usage, em 1987.

A teoria que agora descrevemos baseia-se em alguns conceitos-chave. $\mathrm{O}$ primeiro deles é a noção de Model Person (em tradução literal, "pessoa modelo"), ou MP. Esse indivíduo seria um falante fluente de uma língua natural, dotado de duas características essenciais: racionalidade e face. Assim como os conceitos de língua e falante nativo, sobre os quais falamos no início desse trabalho, para Brown e Levinson (1987) também a ideia de MP é uma abstração: não se teve a intenção de dizer que todos os humanos se comportam da mesma maneira, mas sem esse tipo de abstração não seria possível propor qualquer tipo de teoria.

Por racionalidade, os autores entendem a capacidade de um indivíduo de encontrar os meios que o façam chegar a um determinado fim ou, dito de outro modo, a capacidade de escolher, dentre as estratégias disponíveis, aquelas que satisfaçam suas necessidades. Já o conceito de face, também traduzido para o português como "fachada", tem origem em um termo do inglês utilizado para definir humilhação ou embaraço (losing face), mas também remete ao Ritual de Interação de Goffman (2011 [1967]), que o definiu como 
[...] o valor social positivo que uma pessoa efetivamente reivindica para si mesma através da linha que os outros pressupõem que ela assumiu durante um contato particular. A fachada é uma imagem do eu delineada em termos de atributos sociais aprovados - mesmo que essa imagem possa ser compartilhada, como ocorre quando uma pessoa faz uma boa demonstração de sua profissão ou religião ou ao fazer uma boa demonstração de si mesma. (Goffman, 2011 [1967], p. 13-4)

Para Brown e Levinson (1987), face corresponde à ideia de que cada MP quer ter sua liberdade de ação respeitada e ser aprovado por seus pares. O desejo de manter a possibilidade de fazer escolhas e de agir conforme suas necessidades é sua face negativa e a necessidade de ter a imagem apreciada é sua face positiva. Esse atributo das MPs (que são tanto falantes quanto ouvintes) é permeado por aspectos emocionais e está sujeito a mudanças, podendo ser mantido, reforçado ou perdido, situação chamada de "perda de face". Algo que precisa ser lembrado, uma vez que sua teoria foi criticada por sugerir um caráter universal, é que os autores admitem o fato de os elementos constituintes da face (os limites do território pessoal dos indivíduos, como se constrói sua imagem pública etc.) variarem de uma cultura para outra; o que é universal para eles é o reconhecimento mútuo da imagem pública ou da face de cada indivíduo, bem como a necessidade de considerar esse aspecto durante as interações (Brown e Levinson, 1987, p. 61-62). Nesse sentido, convém apontar que Lakoff (1973, p. 278) também defendia a universalidade das máximas da cortesia, dizendo que elas podem apresentar diferenças dialetais, mas possuem o mesmo esquema básico.

No modelo de Brown e Levinson (1978), a cortesia consiste em uma espécie de jogo de faces, em que o intuito é mantê-las "a salvo", ou agir de modo a afirmá-las, diante de determinados atos de fala que, intrinsecamente, vão contra as necessidades da face positiva e negativa dos falantes, os Face Threatening Acts (FTAs). Os FTAs têm o potencial de:

- ameaçar a face negativa do interlocutor, comprometendo sua liberdade, como ordens, sugestões, ameaças, avisos, desafios, etc.;

- ameaçar a face positiva do interlocutor, por ignorar seus sentimentos ou desejos, tais como críticas, reclamações, acusações, insultos;

- ameaçar a face negativa do falante, como aceitar agradecimentos, pedidos de desculpas ou ofertas;

- ameaçar a face positiva do falante, como pedidos de desculpas, confissões.

Nesse quadro teórico, o pedido, ato fundamental para a pesquisa que aqui apresentamos, é considerado um FTA que ameaça a face negativa do ouvinte, visto que sua liberdade de escolha passa a estar sujeita, de certo modo, à necessidade do falante. Brown e 
Levinson (1987) observaram que, ao classificar certos atos, pode haver sobreposição de categorias e o pedido pode ser um deles: além de ameaçar a face negativa do ouvinte, ele pode comprometer a face positiva do falante, que expõe uma fragilidade ou necessidade que o faz precisar da intervenção do ouvinte ou correr o risco de receber como resposta uma recusa, conforme aponta Vedder $(2007)^{15}$. Retomando o que diz Sbisà (2009 [1989]) a respeito desse ato de fala, o ouvinte passa a ter um poder sobre a situação de dever do falante e, segundo o modelo de Brown e Levinson (1987), isso poderia afetar sua imagem social. Por ter esse potencial de "colocar em dificuldade" tanto falantes quanto ouvintes é que o pedido, como já dissemos em outra oportunidade, é um dos atos de fala mais estudados na área da Pragmática e, particularmente, pelos estudiosos da Cortesia linguística.

Um falante ideal, fazendo uso da racionalidade, tem a possibilidade de escolher a estratégia mais adequada para lidar com um pedido de modo preservar sua própria face e aquela de seu ouvinte. Uma delas é não realizar o FTA e evitar um possível conflito. Por outro lado, se optar por realizá-lo, o falante pode fazê-lo

\section{-on record:}

- sem ação reparadora: de modo direto;

- com ação reparadora: utilizando cortesia positiva, isto é, voltada à face positiva do ouvinte, o que inclui tratá-lo como um amigo ou alguém da família, mostrar que aprecia seu jeito de ser; ou cortesia negativa, relativa à face negativa do ouvinte, mostrando que conhece e respeita suas vontades; ou

- off record: de modo indireto, lançando mão de estratégias como metáforas, ironias, perguntas retóricas, tautologias e quaisquer outras que façam o ouvinte subentender o que o falante realmente quer dizer.

Para determinar o grau de ameaça de um FTA e ser capaz de escolher a melhor estratégia para realizá-lo, Brown e Levinson (1987) sugerem que, em muitas culturas, leva-se em consideração três diferentes fatores, que não são os únicos, mas englobam muitos outros (como status, autoridade, profissão, etnia, fatores situacionais, etc.) e por isso exercem maior influência no processo de avaliação do ato de fala que se pretende realizar. Essas variáveis

\footnotetext{
${ }^{15}$ A propósito disso, ao tratar do cálculo do peso de um FTA, Brown e Levinson (1987) dizem que "[...] requests and offers are likely to threaten the face of both participants", o que essa suposição acerca da ofensa à face negativa do ouvinte e positiva do falante.
} 
sociológicas foram, talvez, o aspecto mais relevante do modelo de Brown e Levinson (1987) para a pesquisa que nos propusemos a realizar, visto que foram considerados tanto durante o planejamento da coleta dos dados quanto durante a análise, como se verá no capítulo 4 . As variáveis a que nos referimos são:

1. a distância social entre falante e ouvinte (que pode ser representada por um eixo horizontal);

2. o poder relativo entre eles (representado por um eixo vertical) e

3. o grau de imposição inerente ao ato de fala em questão nas diferentes culturas ou, em outras palavras, o custo-benefício implicado em realizar determinadas ações..

Após contextualizar e tratar dos aspectos mais importantes do quadro teórico que optamos por utilizar em nossa pesquisa, nos parágrafos a seguir falaremos brevemente de outras possíveis maneiras de entender e descrever o mesmo fenômeno.

Formulada a partir de uma maneira diversa de pensar a Cortesia linguística, Leech, em sua obra intitulada Principles of Pragmatics, elabora o que chamou de Princípio da Cortesia, uma espécie de releitura do Princípio de Cooperação de Grice. Um dos fatores que motivou Leech (1983) a pensar uma alternativa ao que havia sido proposto por Grice (1989 [1967]) foi seu entendimento de que, apesar de o Princípio de Cooperação explicar o processo por meio do qual se chega ao significado de uma implicatura, ele não explicaria o que motiva e regula um comportamento dos falantes que quebra as máximas conversacionais, visando a um comportamento cortês. A cortesia, que para Leech é entendida como o falar ou comportar-se de tal modo a trazer benefícios ou valorizar não a si mesmo, mas ao interlocutor (Leech, 2014, p. 3), seria regulada pelas seguintes máximas:

1 - Máxima do tato: a) minimize o esforço do outro, b) maximize o seu benefício; 2 - Máxima da generosidade: a) minimize o benefício pessoal, b) maximize o esforço pessoal;

3 - Máxima da aprovação: a) minimiza a crítica aos outros, b) maximize a adulação;

4 - Máxima da modéstia: a) minimize a adulação pessoal, b) maximize a crítica pessoal;

5 - Máxima do acordo: a) minimize o desacordo com os outros, b) maximize o acordo;

6 - Máxima da simpatia: a) minimize a antipatia com os outros, b) maximize a simpatia. 
Em 2014, Leech publica o volume The Pragmatics of Politeness, no qual, além de abordar as características do fenômeno da cortesia, alguns modelos propostos desde os anos 1960 e questões metodológicas relativas a pesquisas desenvolvidas nessa subárea da Pragmática, ele repensa as suas Máximas da Cortesia (Leech, 2014, p. 90). A primeira característica dessa reformulação é entender "máxima" como

(a) uma restrição que influencia o comportamento comunicativo dos falantes;

(b) a restrição visa a atingir um objetivo específico;

(c) o objetivo pode ser alcançado em maior ou menor grau, sendo associado a uma escala de valor que se estende de um polo neutro ou negativo para um polo positivo;

(d) máximas podem entrar em conflito ou competir umas com as outras em determinados contextos.

Tendo isso em mente, o estudioso defende que exista uma General Strategy of Politeness - GSP (Estratégia Geral de Cortesia), segundo a qual para ser cortês o falante exprime ou implica significados que associam um valor favorável ao que é relativo ao ouvinte ou um valor desfavorável ao que é relativo a si mesmo (Leech, 2014, p. 90). As máximas associadas a essa estratégia são as mesmas seis que aparecem em Leech (1983), às quais foram acrescentadas aquelas do Sentimento, da Opinião e da Obrigação.

Falando agora das críticas dirigidas a Brown e Levinson (1987), o aspecto mais atacado de sua teoria foi o conceito de face, e as críticas vieram especialmente de pesquisadores especialistas em culturas orientais. Retomando brevemente o que já dissemos sobre esse conceito, a ideia sustentada por Brown e Levinson (1987) é a de que todo indivíduo deseja ter sua imagem social respeitada e aceita (face positiva), ao mesmo tempo em que espera que suas necessidades e liberdade de escolha (ou território) também o sejam (face negativa). Matsumoto (1988), tratando especificamente do comportamento de japoneses, alega que a noção mais estranha às relações sociais nessa cultura é a de face negativa, isso porque a principal preocupação de um indivíduo japonês é reconhecer-se como parte de um coletivo e demonstrar que o faz, e não defender seu próprio território. Desse modo, uma eventual perda de face derivaria do fato de ele causar aos outros membros da sociedade a percepção de que não entendeu o funcionamento e, por conseguinte, seu papel na estrutura hierárquica vigente. $\mathrm{O}$ suposto caráter "individualista" do conceito de face negativa de Brown e Levinson (1987), 
portanto, seria inadequado para descrever a realidade do comportamento linguístico dos japoneses no que diz respeito à cortesia, mesmo que pertinente às culturas europeia e americana.

A atitude de priorizar a observância das regras socialmente estabelecidas para a comunicação verbal ou não-verbal em detrimento da defesa do próprio território é também chamada, como apontam Hill et al. (1986), de wakimae, termo normalmente traduzido como "discernimento". Embora o wakimae tenha importância fundamental e pressuponha um comportamento bem definido por parte dos falantes, há também um aspecto da cortesia que permite o permite escolher, de acordo com suas intenções, algumas estratégias linguísticas. Tal aspecto é denominado "volição". Sendo assim, de acordo com esses estudiosos, pode-se dizer que a cortesia, na sociedade japonesa, não funciona com base em um jogo de faces ou em máximas, mas com base nas noções de discernimento e volição.

O modelo de Brown e Levinson (1987) também não foi considerado adequado para descrever o que ocorre na sociedade chinesa. Segundo Gu (1990), isso se deve ao fato de que, para Brown e Levinson (1987), por exemplo, atos que ameaçam a face negativa do ouvinte, como convidar, fazer ofertas ou promessas, em chinês não tenham essa característica. Outro aspecto discrepante apontado por Gu (1990) é que, nessa sociedade, assim como na japonesa, a cortesia é fortemente normativa e permeada por uma noção de pertencimento a um coletivo que se sobrepõe ao indivíduo. A cortesia em chinês, denominada lîmào, é composta por fatores morais e prevê que o falante aja com respeito, modéstia, uma postura calorosa (attitudinal warmth) e refinamento. Além de apontar as características da cortesia em chinês e as diferenças em relação ao modelo de Brown e Levinson (1987), Gu (1990) propôs quatro máximas que seriam válidas para a sociedade chinesa, baseadas naquelas pensadas por Leech (1983):

- máxima do auto-humilhação: humilhar a si próprio para elevar o outro;

- máxima da "direção": dirigir-se ao interlocutor com a forma de tratamento correta (segundo a posição social);

- máximas do tato e da generosidade: consideradas por Gu (1990, p. 252) como máximas complementares, são similares às de Leech (1983), mas têm como base uma postura calorosa e refinada (no sentido de o comportamento do falante siga o padrão esperado).

Gu (1990) também propõe também o chamado Princípio de Equilíbrio (Balance) da cortesia: segundo esse princípio, por exemplo, uma oferta deve ser respondida com uma contraoferta ou um convite com um outro convite. Ainda no âmbito da cultura chinesa, Mao 
(1994) defende que a dinâmica do funcionamento das faces é diversa daquela descrita por Brown e Levinson (1987) e, portanto, que a universalidade reclamada por eles não se sustentaria. De acordo com Mao (1994), o chinês também conta dois termos que corresponderiam à ideia de face, mas que não seriam conceitualmente equivalentes àqueles de Brown e Levinson (1987). Um deles é miánzi, que diz respeito ao prestígio ou reputação, que podem ser adquiridas ou atribuídas por outros membros da comunidade; o segundo termo é liăn, ligado ao reconhecimento e valorização da moral do indivíduo. Tendo em vista as características apontadas por Brown e Levinson (1987) e por aqueles que se dedicaram as línguas japonesa e chinesa, Mao (1994) propõe que se considerem as culturas centradas no reconhecimento social e hierárquico (como a japonesa e a chinesa) como forças centrípetas, e aquelas voltadas à aos desejos e necessidades dos indivíduos (como aquelas ditas ocidentais) como forças centrífugas. Um modelo que daria conta dessas duas forças opostas seria a chamada Orientação de face relativa, definida como uma abordagem "que emula (ainda que não completamente) um dos ideais interacionais que podem se mostrar mais salientes em uma determinada comunidade de fala: a identidade social ideal ou a autonomia individual ideal" (Mao, 1994, p. 472).

Passando aos estudos relativos à cortesia em língua espanhola, citamos aqui a perspectiva de Diana Bravo, para quem, como lembra Mariottini (2007, p. 49), a cortesia é um fenômeno linguístico, enquanto objeto de estudo da linguística; comunicativo, enquanto objeto de estudo das ciências da linguagem em geral; conversacional, porque a cortesia se manifesta no mínimo em uma estrutura dialógica; e estratégico. A noção de uso estratégico da cortesia é subdivida em duas categorias por Bravo (2001/2005): cortesia normativa, composta por formas convencionais e idiomáticas, de caráter fixo; e cortesia volitiva, de livre escolha do falante. Tais categorias parecem remeter, de alguma maneira, àquelas de discernimento e volição que mencionamos ao falar de Hill et al. (1986) e sua concepção do funcionamento da cortesia na sociedade japonesa.

Assim como fizeram os autores que citamos até agora e que avaliaram criticamente o modelo de Brown e Levinson (1987), Bravo (2003, p. 98-9) também questionou a pertinência do esquema face positiva $v s$ negativa, dizendo que não necessariamente todas as pessoas se preocupam em manter seu território - ou face negativa, e que o que Brown e Levinson entendem por face positiva pode não ser simplesmente o desejo de se sentir aprovado ou de ter suas ideias, desejos e opiniões compartilhadas, isso porque esse tipo de construto só pode ser validado com base em características e regras socioculturalmente estabelecidas. Sendo assim, tanto para agir 
de modo pragmaticamente adequado quanto para entender e descrever os mecanismos da cortesia em uma dada comunidade linguística, é preciso conhecer o papel que aspectos sociais e linguísticos exercem na interação, nas relações sociais.

Considerando que a imagem dos indivíduos é sempre determinada com base nos elementos intrínsecos a cada cultura, Bravo acredita ser plausível considerar duas categorias de análise "vazias" que possam ser preenchidas com as características socioculturais das comunidades linguísticas. Essas duas categorias são a autonomia, que inclui todo comportamento ligados ao modo com que uma pessoa deseja se ver e ser vista como indivíduo dentro do grupo; e afiliação, comportamentos nos quais se percebe que o indivíduo quer se ver e ser visto com parte do grupo, por apresentar as características peculiares a ele peculiares (Bravo, 2003, p. 107).

Também em um contexto hispanófono, assim como fez Bravo (2001/2005), Briz (2004) considera que há tipos diversos de cortesia. Ele propõe duas distinções: cortesia codificada (que preexiste à conversação e está relacionada à noção de convencionalidade) e interpretada (avaliada, negociada no momento da interação); e cortesia monológica (relativa ao falante e dividida entre a que se produz nos atos de fala e no enunciado) e dialógica (inclui a realização da cortesia dentro da sequência interacional). Está inserido no nível monológico da cortesia o aspecto de que se ocupa Briz e o grupo Val.es.co (Valencia Español Coloquial) que parece ser mais relevante para o trabalho que realizamos: o estudo da atenuação. É importante esclarecer, como fez Fraser (1980, p. 343), que atenuação não é sinônimo de Cortesia linguística. A propósito dessa imprecisão conceitual, Briz e Albelda (2013, p. 292) esclarecem que a atenuação é uma categoria pragmática, um mecanismo estratégico e tático, utilizado com vistas a fazer com que a interação seja bem-sucedida; a cortesia, por outro lado, seria uma das motivações para utilizar a atenuação, mas certamente não a única. Também de acordo com Briz e Albelda (2013, p. 302-3), a atenuação tem, basicamente, três funções: a autoproteção, por meio da qual o falante procura não se responsabilizar pelo que diz, escondendo-se atrás de uma espécie de máscara para se proteger de possíveis efeitos negativos; a prevenção, como meio de evitar danos à imagem ou as consequências de uma possível invasão ao território do outro; e a reparação, como meio de remediar um dano já realizado à imagem do outro ou uma invasão ao seu território.

A propósito especificamente dos procedimentos de atenuação, convém falar dos elementos pragmalinguísticos utilizados para isso. Tomemos como ponto de partida o pedido, ato de fala que estudamos. Como se viu na seção anterior, ele ameaça o território do ouvinte 
(sua face negativa, segundo a terminologia proposta por Brown e Levinson, 1987), por menor que seja o favor que se deseja obter. Isso porque o falante tira o ouvinte de sua "zona de conforto" e o leva a, no mínimo, fazer uma série de inferências para avaliar a situação e, no máximo, a ter de realizar algo (concreto ou no campo do discurso) que pode, inclusive, demandar um grande esforço. Induzir, de certo modo, o ouvinte a fazer algo é a força ilocucionária do pedido e o elemento capaz de modificar essa força, atenuando (ou reforçando) seu conteúdo proposicional, é chamado de modificador. A classificação talvez mais conhecida de modificadores é aquela proposta por Blum-Kulka, House e Kasper (1989), que os classificam em morfossintáticos, lexicais e discursivos, além de subdividir os atos de fala em duas unidades de análise: o head act (ato de fala principal, com sua força ilocucionária) e o supportive move (ato de suporte, que, por sua vez, também é um tipo de modificador, por atenuar ou reforçar o ato de fala principal). Inúmeros outros trabalhos sucessivos, no entanto, tomaram essa classificação como ponto de partida, fazendo adaptações que atendam ao tipo de corpus sob análise, como é o caso de Nuzzo (2012), que veremos no capítulo a seguir.

Como lembram Nuzzo e Santoro (2017), um dos objetivos da atenuação da força ilocucionária de um ato de fala, utilizando modificadores (entre outras estratégias), é preservar as relações sociais. Sendo assim, pode-se também dizer que o uso de modificadores é influenciado por variáveis sociológicas, como aquelas individuadas por Brown e Levinson (1987). De fato, na investigação empreendida por Spadotto e Santoro (2016), cujo objetivo era analisar o uso de modificadores e de atos de suporte na fala de falantes nativos de italiano, vemos que esses elementos foram mais frequentes quanto maior era o grau de imposição do pedido e a distância social entre os interlocutores; nesse estudo também se verificou que o uso de modificadores e atos de suporte eram mínimos quando o grau de imposição e a distância social eram baixas.

Após essa breve apresentação de algumas das diferentes abordagens de estudos sobre a Cortesia linguística, vemos que, muito embora o modelo de Brown e Levinson (1978/1987) tenha sido pioneiro e amplamente difuso, várias outras propostas surgiram, na maioria das vezes propostas por pesquisadores fora do âmbito anglófono (em que, na verdade, também nós estamos inseridas), como alternativa a uma visão da cortesia como jogo de faces tida, se como não falha, ao menos como inadequada a certas culturas. Como já sinalizamos anteriormente, utilizamos esse modelo em uma pesquisa envolvendo brasileiros e italianos e, nos resultados, não encontramos indícios que nos fizessem pensar que havia diferenças na "composição" do que Brown e Levinson (1987) chamaram de face negativa ou positiva nas 
culturas que analisamos. Além disso, também as variáveis distância social, poder relativo e grau de imposição se mostraram adequadas à metodologia e à análise dos dados que possuíamos. Portanto, embora conheçamos e compreendamos as observações que fazem os pesquisadores que propuseram outros modelos teóricos, optamos por continuar a utilizar aquele de Brown e Levinson (1987).

Para concluir, é interessante notar que, enquanto Leech publicou em 2014 uma obra em que propõe algumas "melhorias" ao modelo que havia proposto em 1983, por outro lado, Penelope Brown, no artigo Politeness and Language, publicado em 2015, mesmo reconhecendo que há abordagens que veem a cortesia como um conjunto de normas sociais, ou como a "aderência a um modelo de Grice expandido", considera o modelo que idealizou com Stephen Levinson, que vê a cortesia como a atenção estratégica às faces, como o único capaz de dar conta dos aspectos comuns à expressão da cortesia em diversas línguas e culturas (Brown, 2015, p. 326). 


\section{Metodologia}

\subsection{Caracterização da pesquisa: a metodologia mista}

Ao falar, na introdução a este trabalho, de alguns tipos de pesquisa realizados na Pragmática cross-cultural e interlinguística, vimos que muitos deles tratam de descrever e entender os mecanismos envolvidos na realização de pedidos por aprendizes de uma língua estrangeira ou visam a oferecer contribuições ao processo didático de determinadas línguas. Esse tipo de pesquisa não está inserido apenas na área da Pragmática, mas também naquela denominada Second Language Acquisition (SLA), que, como o próprio nome indica, trata de investigar os processos por meio dos quais se aprende uma língua estrangeira ou segunda.

Diversos pesquisadores se debruçaram sobre a questão da metodologia empregada nos estudos de SLA. Com isso, são relativamente numerosas as categorizações encontradas na literatura, e elas frequentemente estabelecem oposições entre duas metodologias que apresentam características distintas. Podemos mencionar, por exemplo, a oposição "pesquisa primária vs pesquisa secundária", descrita por Nunan (1992), em que o primeiro tipo corresponde a pesquisas que recorrem a fontes primárias de dados para, então, empreender uma análise e responder a perguntas previamente definidas, enquanto o segundo corresponde àquelas que envolvem revisão de literatura. Pesquisas primárias, especificamente, podem ser subdivididas em: estudos de caso, cuja ênfase está em documentar a evolução de determinado aspecto da língua-alvo em um indivíduo ou pequeno grupo de aprendizes; e estudos estatísticos, de "natureza transversal", em que se considera possível identificar certos comportamentos de um grupo maior a partir de uma amostra de informantes e se usa a análise estatística para garantir que os resultados não sejam puramente casuais.

Outra oposição bastante utilizada, igualmente descrita por Nunan (1992) e já naquele período considerada "simplista e ingênua", é "pesquisa quantitativa vs pesquisa qualitativa". De acordo com essa classificação, é característico de pesquisas quantitativas ter um alto nível de controle, objetividade e tendência à generalização, além de um considerável distanciamento entre os fatos analisados e o observador/pesquisador; pesquisas qualitativas seriam menos controladas, dando espaço à subjetividade, reconhecendo o papel do contexto em que os dados foram gerados e dando origem a resultados menos generalizantes. Também alegando que a descrição acima é excessivamente simplista, Grotjahn (1987) defende que, para tentar classificar o tipo de pesquisa que se está desenvolvendo, é necessário levar em 
consideração i) o método de coleta de dados (experimental ou não); ii) de que tipo são os dados (quantitativos ou qualitativos) e iii) o tipo de análise a eles aplicado (estatística ou interpretativa). Com base na combinação dessas características, seria possível obter dois paradigmas ditos "puros" e outros seis ditos "mistos". Os paradigmas puros, opostos entre si, são o exploratório-interpretativo, que utiliza dados não-experimentais e qualitativos que são analisados interpretativamente; e analítico-nomotético, que utiliza dados experimentais e quantitativos e, portanto, analisados estatisticamente. Dos seis paradigmas mistos, citamos como exemplo o exploratório-quantitativo-estatístico e o exploratório-quantitativointerpretativo, entre os quais a diferença está apenas no tipo de análise aplicada aos dados, já que nos dois casos os dados são quantitativos.

Tarone (1994), por sua vez, contrapõe as tradições nomotética e hermenêutica, também recorrentes no âmbito da SLA. A primeira tem o intuito de elucidar o funcionamento de determinados fenômenos linguísticos, partindo da ideia de que eles estão inseridos em uma única realidade e de que ocorrem obedecendo a regras precisas (Laws of Nature) - portanto, entre o fenômeno estudado e as regras que o regem há sempre uma relação causal. Nessa tradição, os dados coletados são usualmente experimentais e submetidos a uma análise quantitativa. A tradição hermenêutica, por outro lado, não entende que há apenas uma realidade possível, mas defende que a compreensão dos fenômenos humanos só é possível se levarmos em consideração a multiplicidade de contextos nos quais se inserem. Percebe-se nessa abordagem, como diz a autora, um certo caráter pragmático, baseado na premissa de que o valor do fenômeno deriva mais da sua utilidade em determinados propósitos do que de algum tipo de realidade abstrata e ideal ${ }^{16}$. Em pesquisas desse tipo, portanto, os dados tendem a ser nãoexperimentais, qualitativos, enquanto a análise é de tipo interpretativo. Segundo Markee (1994), no âmbito da SLA, existe uma espécie de "ortodoxia nomotética", ou seja, uma grande adesão a metodologias de caráter nomotético, isso porque os resultados dessa abordagem podem parecer mais convincentes ou causar melhor impressão; entretanto, o autor admite que entre adeptos das duas tradições existe o consenso de que ambas são modos complementares de gerar conhecimento. De fato, apesar de apresentá-las como opostas, Tarone (1994) sugere que elas não sejam vistas como excludentes, mas como uma espécie de continuum no qual estariam postas diversas abordagens de pesquisa.

\footnotetext{
16 "There is thus a kind of pragmatic value assumed in this tradition, an assumption that the value of a phenomenon derives from its usefulness for some propose rather than from some kind of approximation to abstract and ideal Truth" (Tarone, 1994, p.323)
} 
Com base em LeCompte e Goetz (1982), Nunan (1992) descreve as tradições psicométrica e a etnográfica. A linha psicométrica analisa as variáveis tentando encontrar entre elas uma relação de causa e efeito e isolando-as de seu contexto, de modo a evitar variáveis estranhas ao fenômeno estudado. Neste tipo de pesquisa, hipóteses e perguntas de pesquisa normalmente são estabelecidas antes da obtenção dos dados, coletados por meio de metodologias com maior grau de controle, analisados estatisticamente e passíveis de generalização. Para a linha etnográfica, o contexto em que as variáveis ocorrem e a interação entre elas, ou mesmo experiências subjetivas dos participantes da pesquisa, são válidos e de grande importância. Além disso, perguntas e hipóteses, em geral, são formuladas no decorrer da pesquisa, não necessariamente antes da obtenção dos dados, normalmente coletados com menor controle e, portanto, mais propensos a uma análise interpretativa que à generalização. LeCompte e Goetz (1982), resumindo o comportamento dos que adotam uma e outra tradição, dizem que "pesquisadores experimentais (psicométricos) esperam encontrar dados que se encaixem em uma teoria, enquanto etnógrafos esperam encontrar uma teoria que explique seus dados" (p. 33) ${ }^{17}$.

Uma vez que nem sempre as características de uma só tradição atendem às necessidades dos pesquisadores, como vimos em Grotjahn (1987), há pesquisas que empregam mecanismos de tradições usualmente opostas entre si. Em casos assim, temos as chamadas metodologias mistas. A presente pesquisa se insere exatamente nessa categoria, pois apresenta elementos tanto de abordagens de caráter tendencialmente quantitativo (como a nomotética e a psicométrica) quanto de abordagens qualitativas (como a hermenêutica e a etnográfica). Ao mesmo tempo em que temos perguntas de pesquisa previamente definidas e nos baseamos em um quadro teórico para planejar toda a pesquisa, características de linhas ditas quantitativas, não temos grupos que possam ser denominados "experimental e controle" e, portanto, nossos dados não poderiam ser chamados de experimentais. Os dados são, sim, facilmente quantificáveis e passíveis de serem submetidos a uma análise estatística, mas também passarão por uma análise interpretativa baseada, por exemplo, em informações dos participantes, o que é mais típico de pesquisas de viés qualitativo. Conforme Tarone (1994), como vimos ao longo deste capítulo, no campo da SLA há múltiplas realidades e possibilidades de metodologias de pesquisa que constituem um continuиm; em vista disso, o que procuramos fazer foi avaliar quais seriam válidas para o estudo que propusemos.

\footnotetext{
17 "Experimental researchers hope to find data to match a theory; ethnographers hope to find a theory that explain their data" (LeCompte and Goetz, 1982, p. 33)
} 


\subsection{Descrição do corpus Santoro (2012)}

Os pedidos analisados pelos informantes consultados para a presente pesquisa estão contidos em oito vídeos, os mesmos utilizados na pesquisa de IC Cortesia em pedidos em língua italiana: a percepção de brasileiros e italianos. Decidimos utilizar os mesmos pois foi após a análise deles que os informantes anteriores descreveram por escrito suas percepções, a partir das quais elaboramos as categorias que utilizamos no questionário para coleta de dados da presente pesquisa. É um modo de organizar o trabalho que nos pareceu coerente e que nos permitirá testar essas categorias se não em "larga escala", ao menos com um tipo de corpus diferente (com dados mais facilmente quantificáveis), o que pode também permitir que verifiquemos se as tendências identificadas precedentemente se confirmam. Neste capítulo, descreveremos os vídeos em questão, explicando como foram idealizados/realizados, as características que apresentam e o modo em que foram apresentados aos informantes.

Os oito vídeos utilizados nesta pesquisa fazem parte de um corpus de 360 itens gravados durante o estágio de pós-doutorado da Profa. Dra. Elisabetta Santoro, realizado na Università degli Studi di Modena e Reggio Emilia no ano de 2011, com supervisão do Prof. Dr. Gabriele Pallotti. Desses 360 vídeos, 180 são de pedidos e os outros 180 de pedidos de desculpas. Ainda que houvesse parâmetros bem definidos para as gravações, de acordo com os aspectos que se queria observar e de modo que a metodologia empregada pudesse ser reproduzida eventualmente por outros pesquisadores, o intuito era que os atos de fala que nos interessam fossem realizados da maneira mais semelhante possível à fala natural.

Para tal, cada vídeo contou com uma dupla de interlocutores, ambos falantes nativos de italiano, que realizaram role-plays semiabertos. O role-play, que por definição é a "participação em situações sociais simuladas que visam a lançar luz sobre os contextos (papéis e regras) que regem situações sociais reais" 18 , é um recurso muito utilizado por professores línguas estrangeiras para fazer com que os aprendizes exercitem o domínio da língua falada e da dimensão pragmática da interação e também um método amplamente utilizado de eliciação de dados de língua falada. Aquele dito semiaberto, particularmente, é um método considerado de controle intermediário sobre o ato de fala e sobre a relação entre a variável dependente e a variável independente (cf. Santoro, 2012). No corpus a que nos referimos, um dos falantes recebia uma breve indicação do contexto da interação por escrito (prompt), a partir da qual

\footnotetext{
${ }^{18}$ Role playing is defined as participation in simulated social situations that are intended to throw light upon the role/rule contexts governing 'real life' social episodes. (Cohen, Manion \& Morrison, 2007, p. 448)
} 
deveria iniciá-la e, no seu decorrer, realizar o ato de fala esperado. Os interlocutores que deveriam realizar pedidos, ato de fala que nos interessa, recebiam os seguintes prompts:

\begin{tabular}{|c|c|c|c|}
\hline Richiesta & Prompt & Pedido & Prompt \\
\hline Penna & $\begin{array}{l}\text { Sei per strada con un } \\
\text { amico/un 'amica e vuoi } \\
\text { scrivere il numero di } \\
\text { telefono di un annuncio che } \\
\text { vedi passando. Ti accorgi } \\
\text { però di non avere una penna } \\
\text { con te... Che cosa dici? }\end{array}$ & Caneta & $\begin{array}{l}\text { Você está na rua com um } \\
\text { amigo/uma amiga e quer } \\
\text { escrever o número de } \\
\text { telefone de um anúncio que } \\
\text { você vê passando. Percebe, } \\
\text { porém, que está sem } \\
\text { caneta... O que você diz? }\end{array}$ \\
\hline Cellulare & $\begin{array}{l}\text { Sei per strada con un } \\
\text { amico/un'amica e sei in } \\
\text { ritardo. Devi urgentemente } \\
\text { telefonare a un tuo amico } \\
\text { che ha fatto un lungo } \\
\text { viaggio per venire a } \\
\text { trovarti. Il tuo cellulare per } \\
\text { qualche inspiegabile motivo } \\
\text { non funziona e non ci sono } \\
\text { pubblici in giro. Non resta } \\
\text { che cercare un cellulare in } \\
\text { prestito per una telefonata... } \\
\text { Che cosa dici? }\end{array}$ & Celular & $\begin{array}{l}\text { Você está na rua com um } \\
\text { amigo/uma amiga e está } \\
\text { atrasado. Você tem que ligar } \\
\text { com urgência a um amigo } \\
\text { que fez uma longa viagem } \\
\text { para te visitar. Seu celular } \\
\text { por algum motivo não } \\
\text { funciona e não há telefones } \\
\text { públicos nas redondezas. } \\
\text { Não resta que tentar } \\
\text { emprestar um celular para } \\
\text { um telefonema... O que } \\
\text { você diz? }\end{array}$ \\
\hline $\begin{array}{c}\text { Bere } \\
\text { (bicchiere } \\
\text { d'acqua) }\end{array}$ & $\begin{array}{l}\text { Sei appena entrato a casa di } \\
\text { un tuo amico/una tua amica } \\
\text { e hai sete. Che cosa dici? }\end{array}$ & $\begin{array}{c}\text { Beber } \\
\text { (copo d'água) }\end{array}$ & $\begin{array}{l}\text { Você acaba de entrar na } \\
\text { casa de um amigo/uma } \\
\text { amiga e está com sede. O } \\
\text { que você diz? }\end{array}$ \\
\hline $\begin{array}{c}\text { Temporale } \\
\text { (vestiti/doccia) }\end{array}$ & $\begin{array}{l}\text { Sei appena entrato a casa di } \\
\text { un tuo amico/una tua amica } \\
\text { bagnato fradicio perché } \\
\text { fuori sta piovendo a dirotto. } \\
\text { Hai bisogno di farti una } \\
\text { doccia o almeno di toglierti } \\
i \text { vestiti bagnati. Che cosa } \\
\text { dici? }\end{array}$ & $\begin{array}{c}\text { Temporal } \\
\text { (roupa/banho) }\end{array}$ & $\begin{array}{l}\text { Você acaba de entrar na } \\
\text { casa de um amigo/uma } \\
\text { amiga e está completamente } \\
\text { "ensopado" porque fora está } \\
\text { diluviando. Você precisa } \\
\text { tomar um banho ou ao } \\
\text { menos tirar a roupa } \\
\text { molhada. O que você diz? }\end{array}$ \\
\hline
\end{tabular}

Tabela 1 - Prompts entregues aos participantes dos role-plays.

Os quatro tipos de pedidos - caneta, celular, copo d'água, roupa/banho - foram pensados com base nos conceitos de grau de imposição, distância social e poder relativo de Brown \& Levinson (1987). Conforme dissemos na seção 2.3, o primeiro conceito se refere à relação custo-benefício que o ato em questão implica ao interlocutor, em outras palavras, ao esforço que deve ser empregado pelo ouvinte para realizar o pedido de seu interlocutor. Ceder 
rapidamente uma caneta e dar um copo d'água são ações que, na cultura italiana, não exigem tanto esforço para serem realizadas e, portanto, pedidos desse tipo são considerados de baixo grau de imposição. Por outro lado, emprestar um celular, roupas secas ou providenciar um banho a uma pessoa que não reside na casa exigem maior esforço por parte do interlocutor: pedidos dessa natureza, portanto, são considerados de alto grau de imposição.

A distância social (que pode ser representada por um eixo horizontal) e o poder relativo (representado por um eixo vertical) entre os falantes são observados nos diferentes graus de familiaridade existentes entres os interlocutores: eram amigos/familiares ou desconhecidos (ou colegas de trabalho, pessoas que se conheciam há pouco, etc.). Com base no tipo de relação entre eles, foi criada a seguinte escala (para fácil identificação das características das interações):

\begin{tabular}{|c|l|}
\hline Grau de familiaridade & \multicolumn{1}{|c|}{ Condição } \\
\hline $\begin{array}{c}\text { Médio-baixo } \\
\text { Índice de 0-5 }\end{array}$ & $\begin{array}{l}\text { Desconhecidos ou pessoas que se conheciam há pouco; } \\
\text { pessoas cuja relação era marcada por diferenças sociais. }\end{array}$ \\
\hline $\begin{array}{c}\text { Médio-alto } \\
\text { Índice de 6-10 }\end{array}$ & Amigos e membros da família. \\
\hline
\end{tabular}

Tabela 2 - Graus de familiaridade entre os participantes dos role-plays

Outro aspecto levado em consideração foi o de setting, segundo o qual expor os falantes que devem executar o role-play ao ambiente e ao contexto em que o ato de fala esperado normalmente ocorre os ajuda a recuperar mais facilmente suas rotinas linguísticas e, portanto, favorece a realização de atos de fala mais verossímeis. Os pedidos do corpus aqui referido foram gravados em dois settings: "em casa" (onde residia um dos interlocutores) e "na rua". 


\begin{tabular}{|c|c|c|}
\hline Tipo de pedido & Grau de imposição & Setting \\
\hline Caneta (penna) & Baixo & Rua \\
\hline Celular (cellulare) & Alto & Rua \\
\hline Copo d'água (bicchiere d'acqua) & Baixo & Casa \\
\hline Roupas/banho (vestiti/doccia) & Alto & Casa \\
\hline
\end{tabular}

Tabela 3 - Tipos de pedido, grau de imposição e setting.

\subsection{Critérios de escolha dos vídeos}

Durante a pesquisa anterior, o principal critério de escolha dos 8 pedidos/vídeos foi a quantidade de modificadores presente no ato de fala principal (head act), isto é, a parte do enunciado que serve para realizar o ato independentemente de outros elementos - o pedido propriamente dito - de cada vídeo (Blum-Kulka, House e Kasper, 1989). Isso se deve ao fato de, durante a leitura de textos teóricos ou trabalhos empíricos que tratavam da percepção da cortesia de pedidos ou, de qualquer modo, tratavam de aspectos relativos a esse ato de fala, a presença, ausência e mesmo o tipo de modificadores presente era uma questão muito recorrente (cf. Carrel e Konneker, 1981; Faerch e Kasper, 1989; Nuzzo, 2009; Nuzzo e Gauci, 2012). Durante o processo de escolha dos vídeos, procuramos contemplar tanto casos em que os falantes utilizavam muitos modificadores, quanto aqueles realizados sem esses elementos. $\mathrm{O}$ intuito disso foi, além de construir uma amostra variada, verificar se efetivamente uma maior presença de modificadores resultaria em uma percepção mais positiva da cortesia e, por outro lado, se a ausência deles implicaria uma percepção negativa.

Os modificadores encontrados em cada um dos vídeos foram classificados com base na proposta presente no trabalho de Nuzzo (2012, p. 51), que, por sua vez, tomou como ponto de partida a classificação utilizada pelo projeto CCSARP (Blum-Kulka, House e Kasper, 1989), e classificou os modificadores em morfossintáticos e lexicais. Optamos partir do trabalho de Nuzzo pelo fato de também ele analisar dados de língua italiana falada, sempre inserido no âmbito da Pragmática. Nesse estudo, inserido em um volume sobre o ensino da pragmática em italiano L2, a autora investigou, entre outros aspectos, as diferenças entre aprendizes e falantes nativas de italiano quanto modo de realizar pedidos de informações e sugestões, especialmente no que diz respeito ao uso de modificadores. No entanto, as categorias presentes na classificação 
utilizada nesse trabalho não foram suficientes para descrever as ocorrências dos vídeos que havíamos selecionado. Assim, ao grupo dos modificadores lexicais foram acrescentadas as categorias fórmulas de cortesia e reforçadores. Ao grupo dos modificadores morfossintáticos acrescentamos a categoria verbos modais.

\begin{tabular}{|c|c|c|c|}
\hline Tipo & Subtipo & Função & Exemplo \\
\hline \multirow{5}{*}{$\begin{array}{l}\text { Modificadores } \\
\text { morfossintáticos }\end{array}$} & Imperfeito & $\begin{array}{l}\text { Faz parecerem distantes da } \\
\text { realidade o desejo ou a } \\
\text { necessidade daquele que faz } \\
\text { um pedido. }\end{array}$ & $\begin{array}{l}\text { volevo sapere se } \mathrm{mi} \\
\text { potevi::: \# aiutare }\end{array}$ \\
\hline & Condicional & $\begin{array}{l}\text { Faz parecerem distantes da } \\
\text { realidade o desejo ou a } \\
\text { necessidade daquele que faz } \\
\text { um pedido. }\end{array}$ & $\begin{array}{l}\text { avrei bisogno di un } \\
\text { consiglio }\end{array}$ \\
\hline & Verbos modais & $\begin{array}{l}\text { Verbos que, ao acompanharem } \\
\text { outros, exprimem-lhe o sentido } \\
\text { de obrigação, proibição, } \\
\text { necessidade, possibilidade etc. }\end{array}$ & $\begin{array}{l}\text { [mi posso] fare una } . h \\
\text { piccola doccia non so } \\
\text { qualcosa }\end{array}$ \\
\hline & $\begin{array}{l}\text { Fórmulas } \\
\text { dubitativas }\end{array}$ & $\begin{array}{l}\text { Faz com que aquele que pede } \\
\text { pareça em dúvida sobre a } \\
\text { possibilidade de que o pedido } \\
\text { seja atendido. }\end{array}$ & $\begin{array}{l}\text { non so se mi puoi } \\
\text { aiutare per decidere }\end{array}$ \\
\hline & $\begin{array}{l}\text { Interrogativa } \\
\text { negativa }\end{array}$ & $\begin{array}{l}\text { Faz com que aquele que pede } \\
\text { pareça em dúvida sobre a } \\
\text { possibilidade de que o pedido } \\
\text { seja atendido. }\end{array}$ & $\begin{array}{l}\text { non } \grave{e} \text { che tu hai } \\
\text { magari il nome di un } \\
\text { loro album? }\end{array}$ \\
\hline \multirow{6}{*}{$\begin{array}{l}\text { Modificadores } \\
\text { lexicais }\end{array}$} & Duvidador & $\begin{array}{l}\text { Faz com que aquele que pede } \\
\text { pareça em dúvida sobre a } \\
\text { possibilidade de que o pedido } \\
\text { seja atendido. }\end{array}$ & $\begin{array}{l}\text { lei non è che avrebbe } \\
\text { per caso dei cidì in } \\
\text { offerta? }\end{array}$ \\
\hline & Atenuador & $\begin{array}{l}\text { Faz com que o pedido pareça } \\
\text { custar menos ao destinatário. }\end{array}$ & Non so \# un po' $i$ costi \\
\hline & Reforçador & $\begin{array}{l}\text { Aumentam/reforçam a força } \\
\text { ilocucionária do elemento que } \\
\text { acompanham. }\end{array}$ & $\begin{array}{l}\text { mi dai un bicchiere } \\
\text { d'acqua subito subito }\end{array}$ \\
\hline & Preenchimentos & $\begin{array}{l}\text { Faz com que aquele que pede } \\
\text { pareça hesitante. }\end{array}$ & $\begin{array}{l}\text { volevo che::: ehm ciò̀ } \\
\text { che mi consigliassi un } \\
\text { cidì }\end{array}$ \\
\hline & $\begin{array}{l}\text { Fórmulas de } \\
\text { cortesia }\end{array}$ & $\begin{array}{l}\text { Com os quais se pede } \\
\text { explicitamente a colaboração } \\
\text { do interlocutor. }\end{array}$ & $\begin{array}{l}\text { \#\# hai per caso una } \\
\text { penna per piacere }\end{array}$ \\
\hline & Apelo & $\begin{array}{l}\text { Busca chamar a atenção do } \\
\text { destinatário. }\end{array}$ & $\begin{array}{l}\text { ascolti io l'ho } \\
\text { chiamata:: perché } \\
\text { \#0_5 dovrei fare un } \\
\text { regalo }\end{array}$ \\
\hline
\end{tabular}

Tabela 4 - Classificação dos modificadores considerada para a pesquisa 
Um segundo critério de escolha foi que cada setting, grau de imposição e grau de familiaridade fosse representado na amostra submetida à análise dos informantes. Assim, tivemos oito vídeos: para cada um dos quatro tipos de pedidos foram escolhidos dois vídeos, um com médio-alto e um com médio-baixo grau de familiaridade.

Depois de aplicar esses critérios, chegamos ao seguinte elenco de vídeos:

\begin{tabular}{|c|c|c|c|c|l|}
\hline Número & Tipo de pedido & $\begin{array}{c}\text { Grau de } \\
\text { imposição }\end{array}$ & $\begin{array}{c}\text { Grau de } \\
\text { Familiaridade }\end{array}$ & Contexto & $\begin{array}{c}\text { Modificadores } \\
\text { (no ato } \\
\text { principal) }\end{array}$ \\
\hline 1 & Caneta & Baixo & $6-10$ & Rua & $\begin{array}{l}\text { per caso e per } \\
\text { piacere }\end{array}$ \\
\hline 2 & Caneta & Baixo & $0-5$ & Rua & 0 \\
\hline 3 & Celular & Alto & $6-10$ & Rua & un attimo \\
\hline 4 & Celular & Alto & $0-5$ & Rua & $\begin{array}{l}\text { [non è] che, per } \\
\text { caso e avrebbe }\end{array}$ \\
\hline 5 & Água & Baixo & $6-10$ & Casa & subito \\
\hline 6 & Água & Baixo & $0-5$ & Casa & devo e può \\
\hline 7 & Roupas/banho & Alto & $6-10$ & Casa & 0 \\
\hline 8 & Roupas/banho & Alto & $0-5$ & Casa & $\begin{array}{l}\text { Posso, piccola e } \\
\text { non so }\end{array}$ \\
\hline
\end{tabular}

Tabela 5 - Características dos vídeos escolhidos

$\mathrm{Na}$ pesquisa anterior, procuramos, tanto quanto possível, isolar os atos de fala principais, excluindo os chamados atos de suporte ou modificadores externos (Blum-Kulka, House e Kasper, 1989), ou seja, elementos utilizados para preparar ou verificar se o interlocutor está disposto a colaborar, ou para justificar o pedido, etc., especialmente aqueles realizados depois do ato de fala principal, de modo a concentrar a atenção do informante no pedido propriamente dito. Desta vez, optamos por utilizar os vídeos na íntegra, tanto pedidos quanto todos os atos de suporte. Tomamos esta decisão com base nos dados que coletamos naquela ocasião: a ausência/presença de preparações e justificativas foi mencionada muitas vezes para embasar a escolha do nível de cortesia atribuído aos pedidos, tanto que foi necessário criar uma 
categoria para esse tipo de elemento, o que é um indício de que, para os informantes, é relevante não apenas o que está contido no ato de fala principal, mas também aquilo que o precede ou sucede. Além disso, pensando nas noções de efeito e bilateralidade do ato de fala de que falou Sbisà (2009 [1989]), se considerarmos que o sucesso de um ato não depende apenas de como foi realizado, mas também do efeito que dele resultou e do modo em que afetou o interlocutor, não faria sentido excluir partes dos diálogos.

\subsection{Transcrição e preparação dos vídeos}

Para tornar viável a análise dos elementos dos vídeos, realizamos sua transcrição, como é recorrente e fundamental em pesquisas que envolvem língua falada. Para isso, utilizamos, assim como na pesquisa anterior, o método jeffersoniano de transcrição, amplamente utilizado por pesquisadores da área e descrito em detalhes em de Sacks, Schlegoff \& Jefferson (1974). Na seção "anexos", encontra-se a transcrição de todos os vídeos, bem como uma tradução para o português brasileiro.

Uma versão da transcrição em italiano, sem marcações específicas do método jeffersoniano e com pontuação comum, foi utilizada para a inserção de legendas em todos os vídeos, a fim de evitar problemas de compreensão principalmente por parte de brasileiros, mas também, eventualmente, por parte de italianos. Isso porque, como os falantes têm origens e sotaques muito diversos e, como é comum em fala espontânea, há muitas hesitações, falsas partidas e trechos de difícil compreensão, pensamos que fosse possível que houvesse problemas na decodificação do que é dito nos vídeos.

Uma vez realizado esse procedimento, os vídeos foram inseridos no You Tube, a fim de que pudessem ser incorporados aos questionários enviados aos informantes. Posteriormente, utilizando recursos do próprio You Tube, aplicamos aos vídeos um mecanismo que permite desfocar os rostos dos falantes com o intuito preservar sua identidade e privacidade. Adotamos essa medida porque os falantes são italianos e os vídeos circularão na Itália e isso poderia, eventualmente, fazer que fossem reconhecidos e que tivessem algum tipo de constrangimento. É verdade que estudos indicam que expressões ou movimentos faciais podem influenciar a diferenciação de atos de fala (Cruz et al., 2017, em estudo sobre variedades do português europeu) e a percepção da atenuação de atos de fala (Pacheco, 2009, em estudo sobre o português brasileiro), sendo, portanto, uma variável potencialmente importante na atribuição 
do nível de cortesia presente nos pedidos. Entretanto, uma vez que não abordaremos a questão dos movimentos faciais ao longo deste trabalho, decidimos que seria importante que esse aspecto não fosse apresentado aos informantes. O efeito aplicado aos rostos dos falantes, porém, deixou visível o restante de seus corpos e, com base nisso, seria possível questionar se também o movimento de braços e mãos, por exemplo, não seria uma variável importante. Com base nas respostas dos 82 informantes brasileiros e italianos que obtivemos na pesquisa de IC da qual partimos para realizar o presente trabalho, podemos responder negativamente, visto que nenhum dos informantes indicou, em suas respostas escritas, que esse teria sido um elemento determinante para a sua percepção da cortesia.

\subsection{Questionários: embasamento teórico}

Sabemos que foi no campo das Ciências Sociais que o uso de questionários escritos como meio de coletar dados surgiu ou ao menos se estabeleceu, mas também é verdade que isso trouxe importantes contribuições ao campo da SLA. Por meio de instrumentos desse tipo, é possível não apenas coletar dados relativos ao que foi aprendido pelos estudantes, mas também à percepção que têm da língua e da cultura que estão aprendendo. Cabe ao pesquisador planejar cuidadosamente a coleta de dados, garantindo que esse processo seja bem-sucedido, pois, como dizem Dörnyei e Csizér (2012), "nem as técnicas de análise mais sofisticadas são capazes de compensar a ausência de perguntas importantes que, acidentalmente, ficaram de fora da coleta de dados". Nos próximos itens serão explicitadas as etapas envolvidas no planejamento da coleta de dados, da base teórica aos testes piloto.

Dörnyei e Csizér, em How to Design and Analyze Surveys in Second Language Acquisition Research (2012), descrevem como as pesquisas que envolvem questionários são realizadas no âmbito da aquisição de segundas línguas, tratando de aspectos ligados ao planejamento, à coleta e à análise de dados. Foi com base nesse trabalho que o questionário utilizado para a coleta de dados da presente pesquisa foi planejado.

Segundo os autores, para definir o conteúdo de um questionário é preciso delinear e esclarecer as perguntas de pesquisa. Em um momento posterior, ao criar os itens a serem inseridos no questionário, devem ser excluídos aspectos periféricos e não diretamente ligados às variáveis e hipóteses que se quer indagar, de modo a também evitar que o questionário se torne desnecessariamente longo. 
Quanto ao processo de elaboração das questões, que não seria uma tarefa totalmente científica, os autores sugerem que se exercite a criatividade e se elaborem diversas questões potencialmente utilizáveis. Contudo, pode-se partir de dados qualitativos coletados previamente ou ainda de perguntas utilizadas em questionários de outras pesquisas semelhantes. Outro aspecto importante é o modo como se criam as perguntas: escrever itens simples e breves, com uma linguagem natural, evitando palavras ou frases ambíguas ou com carga emotiva, construções negativas ou perguntas duplas ("2 em 1"), é fundamental para não causar problemas de compreensão aos informantes que, devendo dar alguma resposta, farão isso de modo pouco seguro, o que torna os dados pouco confiáveis.

Além de perguntas abertas ou de múltipla escolha, também é possível incluir nos questionários as escalas de avaliação. As escalas encontradas mais frequentemente em pesquisas de diversas áreas são a Likert, que consiste em uma declaração acompanhada de cinco ou seis opções de resposta que variam, por exemplo, de "concordo fortemente" a "discordo totalmente"; a escala diferencial semântica, em que se pede aos informantes que indiquem as suas respostas em um continuиm entre dois adjetivos opostos entre si; e a escala numérica, em que se deve atribuir uma pontuação a uma questão pontual (por exemplo: em uma escala que varia de 1 (mínimo) a 5 (máximo), um informante indica o quanto linguistas são simpáticos).

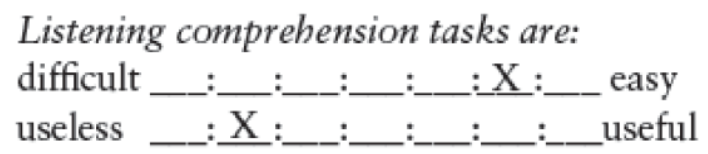

Figura 1 - Exemplo de escala diferencial semântica

O formato ou aparência do questionário tendem a ser considerados supérfluos diante da importância do tema que se pretende investigar, mas, na realidade, também merecem atenção por parte dos pesquisadores, pois influenciam a experiência do informante e, consequentemente, a qualidade dos dados. Para Dörnyei e Csizér, o ideal é que os questionários não tenham mais de duas a seis páginas e nem um tempo de resposta superior 30 minutos. Além disso, ainda que os informantes prefiram um questionário de dois a um de cinco páginas, convém evitar inserir muitos itens em uma só página e é interessante alternar tipos de perguntas e escalas para que o questionário não pareça repetitivo e evitar que os informantes simplesmente repitam a resposta do item anterior. Outra decisão que pode gerar resultados positivos é inserir a ficha de dados que permitem ao pesquisador traçar um perfil sociolinguístico do informante 
no final do questionário, já que se deparar com uma série de perguntas de cunho pessoal logo no início pode despertar dúvidas ou inseguranças sobre a privacidade.

Uma vez elaborada uma primeira versão do questionário, é necessário verificar se há perguntas excessivamente difíceis ou impertinentes, se há erros, qual o tempo de resposta e se os dados chegam ao pesquisador da maneira esperada. Para isso, realiza-se um teste piloto, que pode consistir no chamado Think Aloud Protocol, isto é, em pedir que três ou quatro pessoas respondam ao questionário e digam com detalhes ao pesquisador a impressão que tiveram. Naturalmente, é possível realizar um teste piloto a distância, desde que o pesquisador receba o feedback de que necessita. Sendo presencial ou à distância, esse procedimento permitirá que se chegue a uma versão final mais confiável.

O próximo passo seria passar à coleta de dados. Antes disso, no entanto, é preciso ter em mente a dimensão da amostra que se pretende coletar, ou seja, a quantidade de indivíduos, e também que características eles devem apresentar. Essas informações serão descritas mais adiante no item "Tamanho da amostra, perfil dos informantes e coleta dos dados".

\subsubsection{Características dos questionários}

Tendo em vista os conceitos expostos anteriormente a respeito do planejamento da coleta de dados e as peculiaridades da pesquisa que desenvolvemos, elaboramos os questionários a serem enviados aos informantes brasileiros e italianos utilizando a plataforma Google Forms, acessível por meio do Google Drive ${ }^{19}$. O primeiro aspecto a ser decidido foi o idioma dos questionários. Se na pesquisa anterior o questionário enviado aos italianos era em italiano e aquele enviado aos brasileiros em português (ambos com vídeos com áudio e legendas em italiano), nesta optamos por fazer ambos os questionários em italiano, partindo do pressuposto de que, se os informantes brasileiros possuem um domínio da língua que lhes

\footnotetext{
${ }^{19}$ Para que se possa visualizar na íntegra os questionários utilizados para a coleta dos dados, incluímos aqui os links para acesso às versões enviadas aos italianos e aos brasileiros.

Italianos:

https://docs.google.com/forms/d/e/1FAIpQLSdLao2NrkI4pwV8pNs50i_VC490al-

bM0TE46fHM5cGyPU8sQ/viewform

Brasileiros:

https://docs.google.com/forms/u/1/d/e/1FAIpQLScwlqAvso5HotLuIx1IAqDBbFAFgSaOizg6UR_rK0cqqdt$\underline{\mathrm{xQ} / \text { viewform }}$
} 
permite entender e avaliar os pedidos em italiano, também serão capazes de compreender as perguntas nessa língua, até porque tínhamos como premissa básica criar perguntas simples e claras.

Após decidir o idioma dos questionários, a primeira etapa foi elaborar um texto de uma apresentação da pesquisa e do próprio questionário. Procuramos dar informações básicas que permitissem ao informante ter alguma noção do trabalho que estava sendo desenvolvido e dos pesquisadores envolvidos, sem ser excessivamente detalhistas. Chegamos à seguinte fórmula, apresentada abaixo primeiro em italiano e depois em português brasileiro:

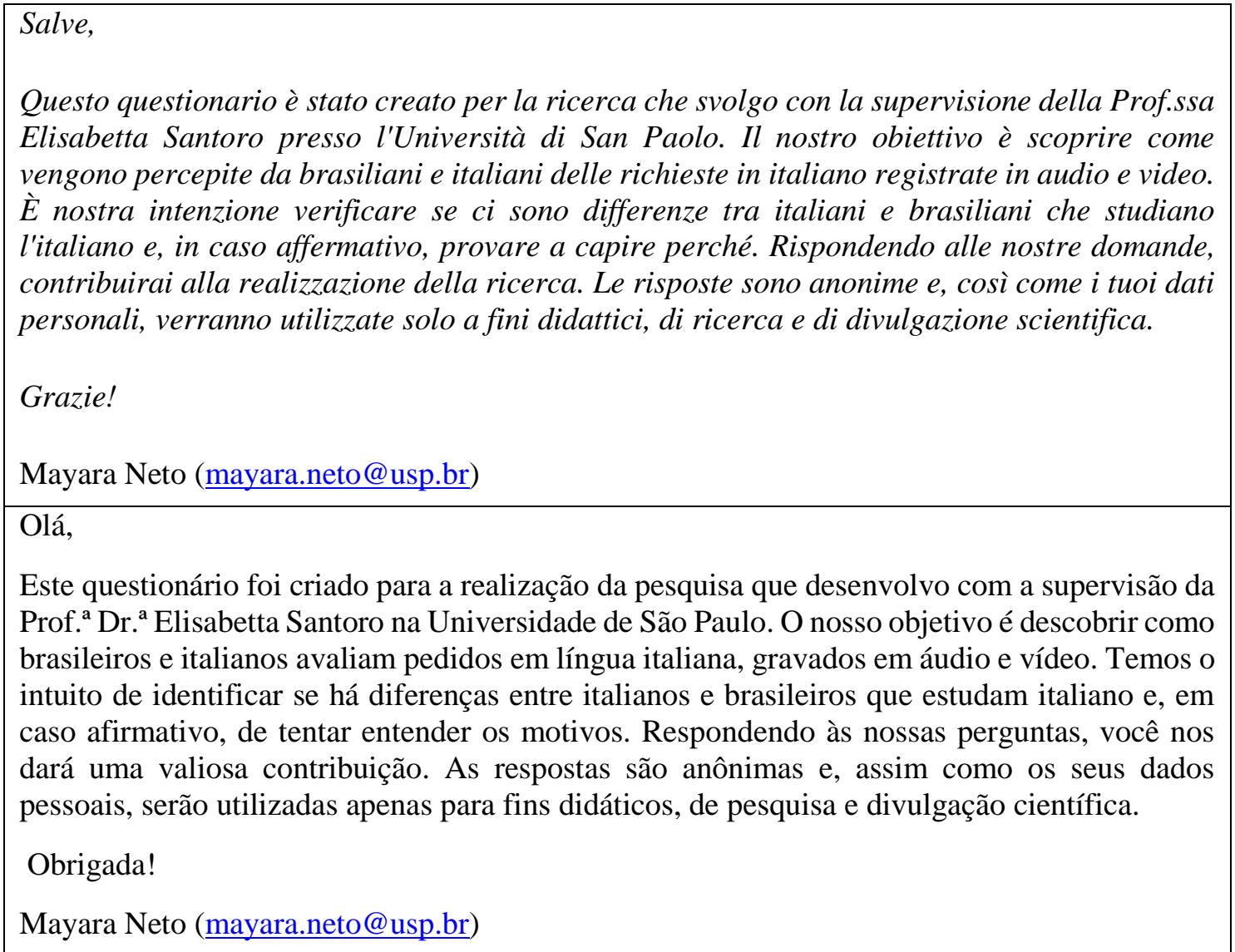

Tabela 6 - Texto de apresentação da pesquisa

Em seguida, elaboramos uma pequena descrição do que o informante encontraria nas páginas seguintes, com o intuito de tornar todo o processo transparente e de tornar o informante consciente da tarefa a ser realizada. 
Nelle domande che seguiranno ti verrà chiesto di dare le seguenti informazioni: i. classificare il grado di gentilezza/cortesia di una serie di richieste; ii. per ciascuna richiesta, indicare quali caratteristiche della richiesta stessa ti hanno portato a ritenerla più o meno gentile/cortese. Quando avrai finito di valutare le richieste, troverai una scheda da essere compilata con alcuni dati su di te, sempre esclusivamente a fini didattici, di ricerca e di divulgazione scientifica.

Nas perguntas a seguir pediremos que nos dê as seguintes informações: i. classificar o grau de gentileza/cortesia de uma lista de pedidos; ii. Para cada pedido, indicar quais características the levaram a considerá-la mais ou menos gentil/cortês. Após a avaliar os pedidos, você encontrará uma ficha a ser preenchida com alguns dados pessoais, sempre para fins didáticos, de pesquisa e divulgação científica.

Tabela 7 - Instruções sobre o preenchimento do questionário

O próximo passo foi incorporar ao questionário os vídeos em italiano, previamente legendados, carregados no You Tube e com os rostos dos falantes desfocados. Uma vez que após os vídeos seriam inseridas as perguntas por meio das quais eliciaríamos os níveis de cortesia atribuídos a cada pedido e os motivos para a seleção desses níveis, nesse ponto do desenvolvimento do projeto tivemos de tomar duas decisões importantes. A primeira era se deveríamos incluir um nível "zero" na escala utilizada para avaliar a cortesia presente nos pedidos. Partindo do pressuposto (baseado em conhecimentos empíricos e na própria reação dos que interagiam com os falantes que realizaram os pedidos nos vídeos) de que nenhum deles foi tão descortês a ponto de receber uma avaliação do tipo, optamos por não o fazer. 
Video 1

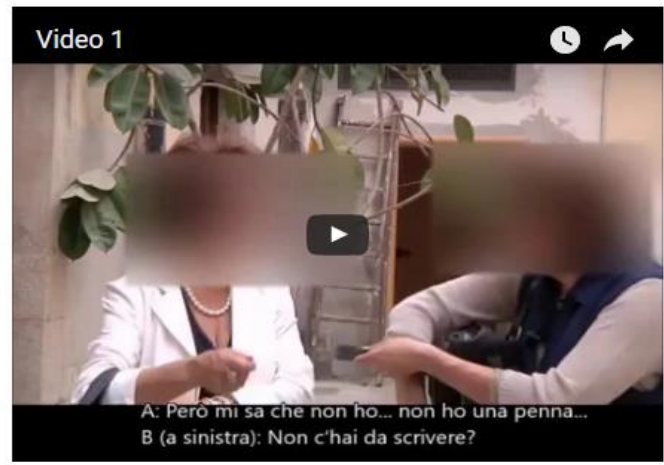

1- Secondo te, qual è il livello di gentilezza/cortesia presente nella richiesta che hai appena visto? *

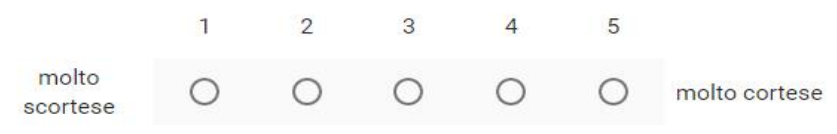

Figura 2 - Vídeo 1 e escala de avaliação do nível de cortesia

A partir da figura 2, é possível visualizar que no extremo da escala mista correspondente ao nível mais alto de cortesia há a indicação molto cortese (muito cortês), enquanto no extremo oposto a indicação é molto scortese (muito descortês). É importante esclarecer que, quando nos referimos a "descortesia" ao longo deste trabalho ou quando utilizamos esse termo nos questionários enviados aos informantes, referimo-nos a uma percepção de ausência de cortesia no pedido em questão e não à ideia de descortesia como "uso de estratégias comunicativas pensadas para atacar a face de outrem, causando, desse modo, conflito social e desarmonia" (Culpeper, Bousfield e Wichmann, 2003, p. 1545). Isso porque, como sabemos, há um filão de pesquisas que se interessa não apenas por analisar as estratégias utilizadas por falantes para serem descorteses e os elementos contextuais que levam a esse comportamento linguístico, mas também por criar um quadro teórico para esse fenômeno, tal qual fizeram Brown e Levinson (1987) com a Cortesia (Culpeper, 1996).

A segunda decisão importante durante a elaboração dos questionários foi definir se as perguntas seriam abertas ou fechadas. Na pesquisa que concluímos anteriormente, além da escala que utilizamos para avaliar o nível de cortesia dos pedidos, havia apenas uma pergunta aberta à qual os informantes deveriam responder expondo os elementos que os levaram a selecionar determinado nível. A partir das informações de todas as respostas abertas válidas, criamos categorias para organizar os elementos apontados pelos informantes, de modo a expor 
os resultados de maneira mais organizada. Dado que nosso intuito no presente era verificar se as tendências apontadas no trabalho anterior se confirmavam em um corpus mais amplo ou mais facilmente quantificável, consideramos plausível utilizar as categorias que mais foram mencionadas pelos informantes, o que implicava em utilizar um questionário fechado. As categorias incluídas são:

- Modificadores lexicais: os elementos citados na classificação que utilizamos baseada em Nuzzo (2012) (ver tabela 4, p. 65). Acrescentamos a essa categoria, no questionário, as "saudações" e os "agradecimentos";

- Modificadores morfossintáticos: elementos indicados na classificação que utilizamos baseada em Nuzzo e Gauci, 2012 (ver tabela 4, p. 65);

- Grau de familiaridade;

- Grau de imposição;

- Entoação;

- Atos de suporte: preparações ou justificativas (frequentemente denominadas "explicações" pelos informantes) para os pedidos;

- Forma de tratamento: casos em que os informantes citavam o uso dos pronomes italianos $t u$ (você) e lei (o senhor/a senhora), que são traços típicos de tratamento informal e formal, respectivamente. Também estão classificadas aqui as respostas de tipo "tratamento formal" ou "informal".

Como já foi indicado na lista acima, adicionamos ao grupo dos modificadores lexicais que havíamos considerado na pesquisa anterior as "saudações", que para alguns podem ser consideradas uma espécie de "apelo", categoria que já existia na classificação que havíamos utilizado. Optamos por empregar essa distinção porque os apelos foram utilizados para abordar e realizar imediatamente o pedido a interlocutores com os quais o grau de familiaridade era médio-baixo (vídeos 2 e 5) ou para chamar a atenção de um interlocutor com quem o grau de familiaridade era médio-alto (vídeos 1 e 3) durante interações que já estavam em curso, enquanto as saudações foram utilizadas em situações em que os falantes (próximos ou não) acabavam de se encontrar (vídeos 5, 6 e 8) e em que, além disso, optou-se por não realizar o pedido de imediato. Quanto aos "agradecimentos", sua inclusão deve-se ao fato de que tenhamos decidido utilizar os vídeos na íntegra e, portanto, também com o que era dito após o ato de fala principal.

A seguir encontra-se uma tabela com o elenco das 19 variáveis inseridas no questionário, em que se indica se elas estão presentes ou ausentes nos oito pedidos apresentados aos informantes, sempre na fala de quem realizou os pedidos e tanto no ato de fala principal quanto nos atos de suporte (quando houver). Na primeira coluna da tabela estão as siglas que 
serão utilizadas durante a análise dos dados para identificar as categorias abordadas. Vale dizer que os modificadores lexicais compreendem as variáveis Q1 a Q8, enquanto os morfossintáticos correspondem às variáveis Q9 a Q13. 


\begin{tabular}{|c|c|c|c|c|c|c|c|c|c|}
\hline Siglas & Variáveis & $\begin{array}{c}\text { Vídeo } \\
1 \\
\end{array}$ & $\begin{array}{c}\text { Vídeo } \\
2 \\
\end{array}$ & $\begin{array}{c}\text { Vídeo } \\
\mathbf{3} \\
\end{array}$ & $\begin{array}{c}\text { Vídeo } \\
4 \\
\end{array}$ & $\begin{array}{c}\text { Vídeo } \\
5 \\
\end{array}$ & $\begin{array}{c}\text { Vídeo } \\
6 \\
\end{array}$ & $\begin{array}{c}\text { Vídeo } \\
7 \\
\end{array}$ & $\begin{array}{c}\text { Vídeo } \\
8 \\
\end{array}$ \\
\hline Q1 & Saudações & Não & Não & Não & Não & ciao & $\begin{array}{l}\text { Buon } \\
\text { giorno }\end{array}$ & Não & ciao \\
\hline Q2 & Agradecimentos & Sim & Sim & Sim & Sim & Sim & Sim & Sim & Sim \\
\hline Q3 & $\begin{array}{l}\text { Fórmulas de } \\
\text { cortesia }\end{array}$ & $\begin{array}{c}\text { per } \\
\text { piacere }\end{array}$ & $\begin{array}{c}m i \\
\text { dispiace }\end{array}$ & Não & Não & Não & Não & Não & Não \\
\hline Q4 & Duvidadores & $\begin{array}{c}\text { per caso } \\
\text { / mi sa } \\
\text { che }\end{array}$ & Não & Não & $\begin{array}{l}\text { per } \\
\text { caso }\end{array}$ & Não & Não & Não & $\begin{array}{l}\text { Possibil- } \\
\text { mente }\end{array}$ \\
\hline Q5 & Atenuadores & Não & Não & $\begin{array}{c}\text { un } \\
\text { attimo }\end{array}$ & Não & Não & Não & Não & piccola \\
\hline Q6 & Reforçadores & Não & Não & urgente & urgente & $\begin{array}{c}\text { subitol } \\
\text { sto } \\
\text { morendo }\end{array}$ & Não & $\begin{array}{l}\text { bagnati } \\
\text {-ssima }\end{array}$ & $\begin{array}{c}\text { a dirotto, } \\
\text { tutta } \\
\text { sporca }\end{array}$ \\
\hline Q7 & Preenchimentos & Não & Não & Não & Não & Não & Não & Não & Não \\
\hline Q8 & $\begin{array}{l}\text { Fórmulas de } \\
\text { apelo }\end{array}$ & $\begin{array}{c}\text { Vedi / } \\
\text { guarda }\end{array}$ & mi scusi & $\begin{array}{c}\text { Senti / } \\
\text { escolta / } \\
\text { aspetta }\end{array}$ & Não & scusami & Não & Não & Não \\
\hline Q9 & Imperfeito & volevo & Não & Não & Não & Não & Sim & Não & Não \\
\hline Q10 & Condicional & Não & Não & Não & $\begin{array}{c}\text { avrebbe } \\
\text { (avere) }\end{array}$ & Não & Não & Não & $\begin{array}{c}\text { avrei } \\
\text { (avere) }\end{array}$ \\
\hline Q11 & Verbos modais & $\begin{array}{l}\text { volevo } \\
\text { (volere) }\end{array}$ & Não & $\begin{array}{c}\text { debbo } \\
\text { (dovere) }\end{array}$ & $\begin{array}{c}\text { posso } \\
\text { (potere) }\end{array}$ & Não & $\begin{array}{c}\text { può } \\
\text { (potere) }\end{array}$ & Não & $\begin{array}{c}\text { posso } \\
\text { (potere) }\end{array}$ \\
\hline Q12 & $\begin{array}{l}\text { Fórmulas } \\
\text { dubitativas }\end{array}$ & Não & Não & Não & Não & Não & Não & Não & non so \\
\hline Q13 & $\begin{array}{c}\text { Interrogativas } \\
\text { negativas }\end{array}$ & Não & Não & Não & $\begin{array}{c}\text { [non è] }] \\
\text { che }\end{array}$ & Não & Não & Não & Não \\
\hline Q14 & $\begin{array}{c}\text { Grau de } \\
\text { Familiaridade }\end{array}$ & $6-10$ & $0-5$ & $6-10$ & $0-5$ & $6-10$ & $0-5$ & $6-10$ & $0-5$ \\
\hline Q15 & $\begin{array}{c}\text { Grau de } \\
\text { Imposição }\end{array}$ & Baixo & Baixo & Alto & Alto & Baixo & Baixo & Alto & Alto \\
\hline Q16 & Entoação & - & - & - & - & - & - & - & - \\
\hline Q17 & Preparadores & Não & Não & Não & Não & Não & Sim & Não & Sim \\
\hline Q18 & Justificativas & Sim & Não & Sim & Sim & Sim & Não & Sim & Não \\
\hline Q19 & $\begin{array}{l}\text { Formas de } \\
\text { tratamento }(t u \\
\text { ou lei) }\end{array}$ & $t u$ & lei & $t u$ & lei & $t u$ & $l e i$ & $t u$ & tu/lei \\
\hline
\end{tabular}

Tabela 8 - Detalhes das variáveis utilizadas para justificar o nível de cortesia 
A pergunta número 1 do questionário que utilizamos em nossa pesquisa indaga sobre o nível de cortesia presente no pedido em questão e conta com uma escala mista (numérica e diferencial semântica), que contém os níveis de 1 ("muito descortês") a 5 ("muito cortês"). As perguntas de 2 a 8 são sobre as variáveis citadas acima. Para cada uma das variáveis presentes nas perguntas há uma escala de avaliação numérica, em que o número 0 representa nenhuma importância e o 5 máxima importância. No enunciado das questões relativas aos modificadores lexicais e morfossintáticos e aos atos de suporte (preparadores e justificativas), questionamos o quanto a ausência ou presença desses elementos foi importante para a percepção da cortesia. Dado que estes elementos estavam sempre presentes nos pedidos, sobre as categorias grau de familiaridade (apresentada como "relação entre os falantes"), grau de imposição (definida aos informantes como "tipo de pedido realizado em tem), entoação e forma de tratamento ( $t u$ ou $l e i)$ perguntava-se apenas o quanto eles tinham sido importantes para definir o nível de cortesia atribuído ao pedido em análise (não se falava em presença ou ausência).

Conforme já dissemos, a pergunta número 1 é relativa ao nível de cortesia presente nos pedidos. A pergunta número 2, por sua vez, continha as oito variáveis da categoria modificadores lexicais. Por se tratar de uma pergunta com muitos itens, que eventualmente poderiam gerar dúvidas, incluímos logo abaixo das variáveis lexicais um espaço para que os informantes, se achassem necessário, exprimissem uma opinião ou fizessem quaisquer comentários. 
2- Quanto sono stati importanti gli elementi elencati sotto per farti valutare la richiesta del video 1 in questo modo? N.B.: 0 (zero) $=$ nessuna importanza $/ 5$ (cinque) $=$ massima importanza .$$
\text { * }
$$

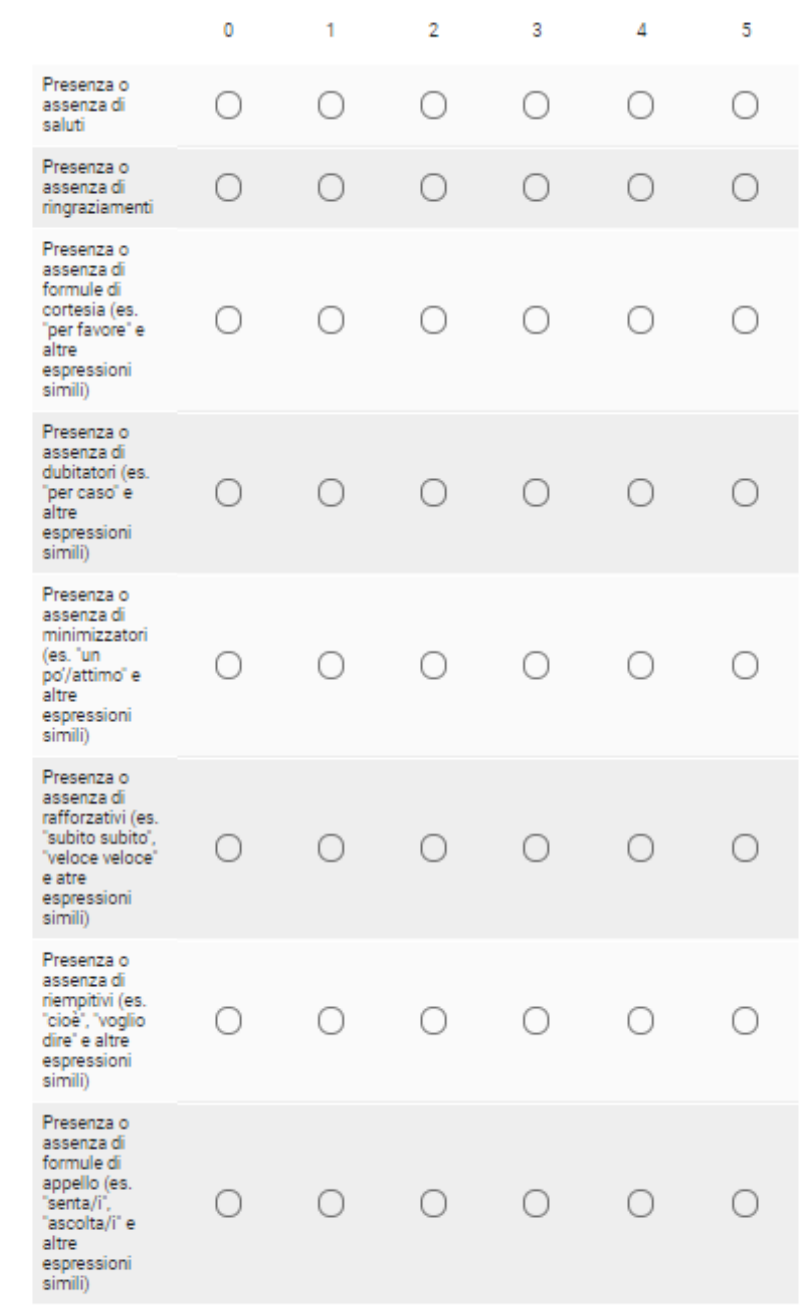

Figura 3 - Pergunta número 2 (modificadores lexicais)

A pergunta número 3 trata dos modificadores morfossintáticos e foi elaborada aos moldes da pergunta anterior: apresenta as categorias ligadas à classe de modificadores em questão, uma escala numérica para avaliação e um espaço para eventuais comentários. 
3- Quanto sono stati importanti gli elementi elencati sotto per

farti valutare la richiesta del video 1 in questo modo? N.B.: 0

(zero) $=$ nessuna importanza $/ 5$ (cinque) $=$ massima importanza .

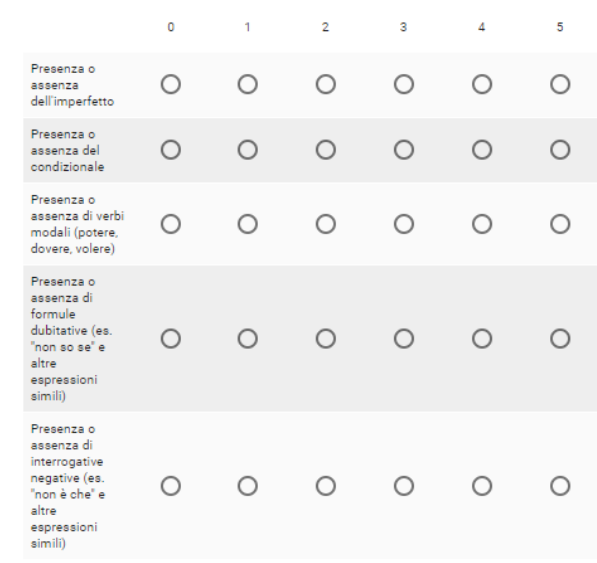

3a-Se hai commenti da fare, utilizza questo spazio

Figura 4 - Pergunta número 3 (modificadores morfossintáticos)

Com o item de número 4 pretendíamos investigar o quanto o grau de familiaridade influenciava a percepção da cortesia. No entanto, o termo adotado no questionário foi "relação entre os falantes", dando como exemplo o fato de que sejam amigos, familiares, desconhecidos e etc. Neste caso, visto que não havia necessidade de subdividir as opções de resposta, o informante deveria apenas indicar, em uma escala diferencial semântica e numérica (mista), o quanto considerou importante esse fator para assinalar o nível de cortesia do pedido avaliado.

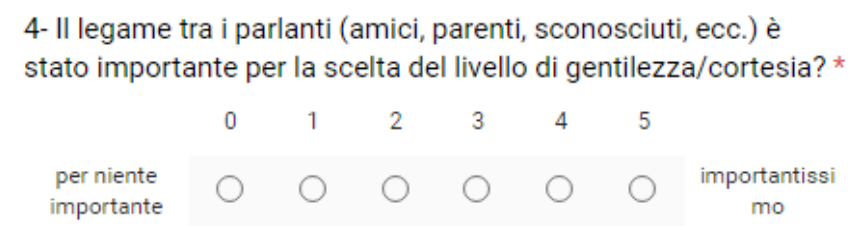

Figura 5 - Pergunta número 4 (grau de familiaridade)

O aspecto abordado no item de número 5 foi o grau de imposição, que, para evitar problemas de compreensão, foi denominado "tipo de pedido", com a descrição "fácil ou difícil de realizar". A escala utilizada para avaliar esse aspecto também foi mista. 


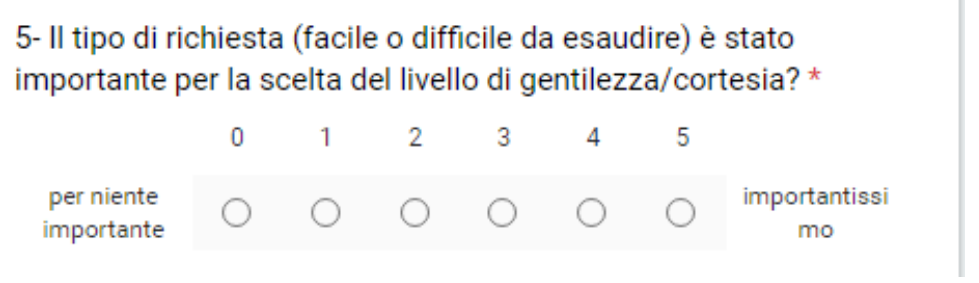

Figura 6 - Pergunta número 5 (grau de imposição)

No item de número 6, pediu-se ao informante que avaliasse o quanto a entoação ou tom de voz influenciaram a percepção da cortesia. A escala de avaliação é a mesma do item anterior e, neste caso, não achamos necessário mudar a terminologia utilizada.

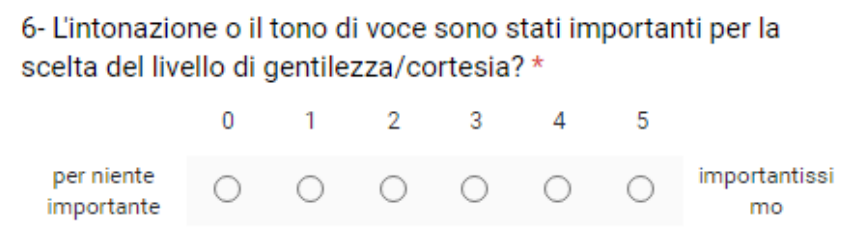

Figura 7 - Pergunta número 6 (entoação/tom de voz)

A importância dos atos de suporte para a percepção da cortesia foi a variável eliciada na questão de número 7, subdividida em "preparação" e "justificativa". Desta vez, a escala utilizada foi apenas numérica, de 0 (nenhuma importância) a 5 (máxima importância).

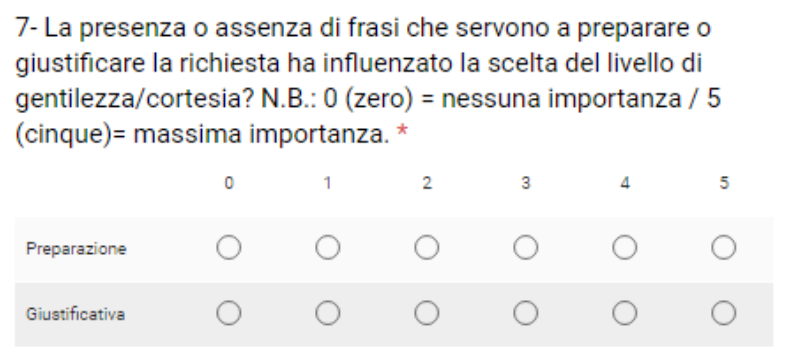

Figura 8 - Pergunta número 7 (atos de suporte)

No último item, de número 8, pedimos que o informante indicasse o quanto a forma de tratamento, indicada como tu (você) ou lei ("a senhora/o senhor"), foi importante para selecionar o nível de cortesia. Neste caso, a escala voltou a ser diferencial semântica e numérica. 


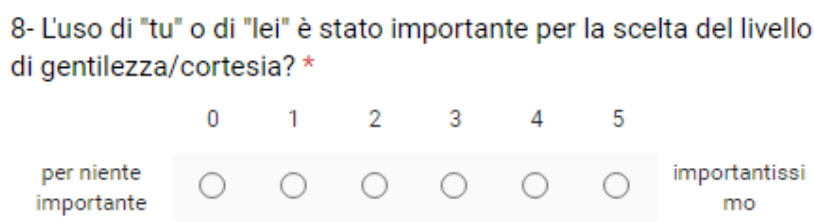

Figura 9 - Pergunta número 8 (formas de tratamento)

Após responder às oito perguntas para cada um dos oito vídeos/pedidos, o informante chegava à última etapa de sua colaboração, fornecendo alguns dados pessoais, o que já era de seu conhecimento desde a apresentação do questionário. Foram solicitadas as seguintes informações:

- idade;

- gênero;

- país de residência;

- cidade de nascimento;

- cidade de residência;

- formação escolar;

- curso superior;

- profissão;

- se o informante já havia exercido alguma outra profissão que valesse a pena ser citada;

- se na casa em que cresceu se falava dialeto ou outras línguas, quais, com que frequência e em quais situações;

- se na casa onde vivia se falava dialeto ou outras línguas, quais, com que frequência e em quais situações;

- quais línguas estrangeiras conhecia (em uma lista com as seguintes opções: inglês, alemão, espanhol, francês, português brasileiro, português europeu, japonês, chinês, russo ou outras).

A ficha de dados pessoais também era em italiano tanto para os brasileiros quanto para os italianos, com apenas duas diferenças. No caso dos brasileiros, as perguntas que diziam respeito a falar dialetos na casa em que se nasceu ou se vivia foram excluídas, dado que não condizem com a realidade linguística da maioria dos brasileiros. Além disso, para a escolaridade dos brasileiros as opções eram em português, pois não há correspondência exata 
entre os sistemas brasileiro e italiano, nem no que diz respeito à terminologia utilizada para denominar os níveis de ensino.

\subsection{Teste piloto: procedimentos e resultados}

Com o intuito de verificar se os questionários que elaboramos eram suficientemente confiáveis para a realização da coleta dos dados, realizamos um teste piloto com quatro informantes, dois brasileiros e dois italianos. A informante brasileira tinha 30 anos, nasceu e era residente em São Paulo (SP) e era mestranda do Programa de Pós-Graduação em Estudos da Tradução da Universidade de São Paulo (USP). O informante brasileiro tinha 31 anos, de Colatina com residência em Vitória (ES) e era estudante do curso de Letras - português e italiano da Universidade Federal do Espírito Santo (UFES). O informante italiano tinha 26 anos, era de Brescia $^{20}$ (província de Brescia - BS), mas residia em Bagolino (BS) e era estudante de Engenharia. A informante italiana tinha 19 anos, era de Marsicovetere (província de Potenza PZ) mas residia em Montemurro (PZ) e estudava História e Tutela de Bens Artísticos e Musicais.

A esses informantes foi solicitado que observassem se as perguntas e escalas de avaliação eram claras, se os vídeos apresentavam qualquer tipo de problema e quanto tempo levaram para responder a todas as perguntas. Pedimos também que fizessem quaisquer observações que julgassem relevantes. O informante italiano notou que o efeito que desfoca o rosto dos falantes encobria a legenda em alguns vídeos. A partir deste comentário, realizamos a correção do problema manualmente, isto é, sem utilizar o recurso do You Tube que desfoca os rostos de modo automático. Seu tempo de resposta foi de 26 minutos ao todo. A informante italiana comentou que o termo "morfossintático" da pergunta número 3 causou um certo "espanto" inicialmente, mas que ao ler as categorias foi possível entender perfeitamente do que se tratava. Em resposta a isso, para evitar que outros informantes tivessem a mesma impressão, decidimos reformular os enunciados e excluir os trechos que aludiam ao caráter lexical da pergunta 2 e morfossintático da pergunta 3. Essa mesma informante italiana levou 30 minutos para responder a todo o questionário. O informante brasileiro levou 25 minutos para responder

\footnotetext{
${ }^{20}$ Os informantes italianos de nossa pesquisa, em geral (não somente os do teste piloto), são oriundos de diversas localidades da Itália que, na maior parte dos casos, são pouco conhecidas. Uma vez que apenas os topônimos italianos mais amplamente conhecidos possuem correspondentes em português (Milano/Milão, Venezia/Veneza, Padova/Pádua, etc.), optamos por sempre utilizar os originais em italiano.
} 
a todas as perguntas e não informou qualquer tipo de problema. A informante brasileira levou 45 minutos para responder o questionário, mas atribuiu seu elevado tempo de resposta à sua necessidade pessoal de rever os vídeos quantas vezes achou necessário, mudando eventualmente respostas que havia dado anteriormente. Também essa informante não fez observações ou sugestões.

Nenhum dos quatro informantes reportou falta de clareza das perguntas ou escalas e o tempo médio de resposta foi de 31,5 minutos. Retomando o que dizem Dörnyei e Csizér (2012) a respeito do tempo de resposta ideal de um questionário, que deveria ser de no máximo 30 minutos, o tempo médio de resposta do questionário piloto excedeu apenas minimamente a expectativa. No entanto, deve-se considerar que foi apenas por uma característica intrínseca a um dos informantes. Sendo assim, consideramos que essa versão, depois do ajuste dos vídeos, poderia ser utilizada para a coleta dos dados definitivos.

Quanto a modo de acesso às respostas dos informantes, a plataforma Google Forms/Drive permite que elas sejam visualizadas de pelo menos três maneiras: resumida, ou seja, agrupando as respostas de todos os informantes; individual, exibindo o layout do questionário original com as respostas assinaladas pelo informante; e por meio de uma planilha de Excel. O modo resumido reúne os dados dos informantes e os transforma em gráficos, de modo a facilitar a visualização.

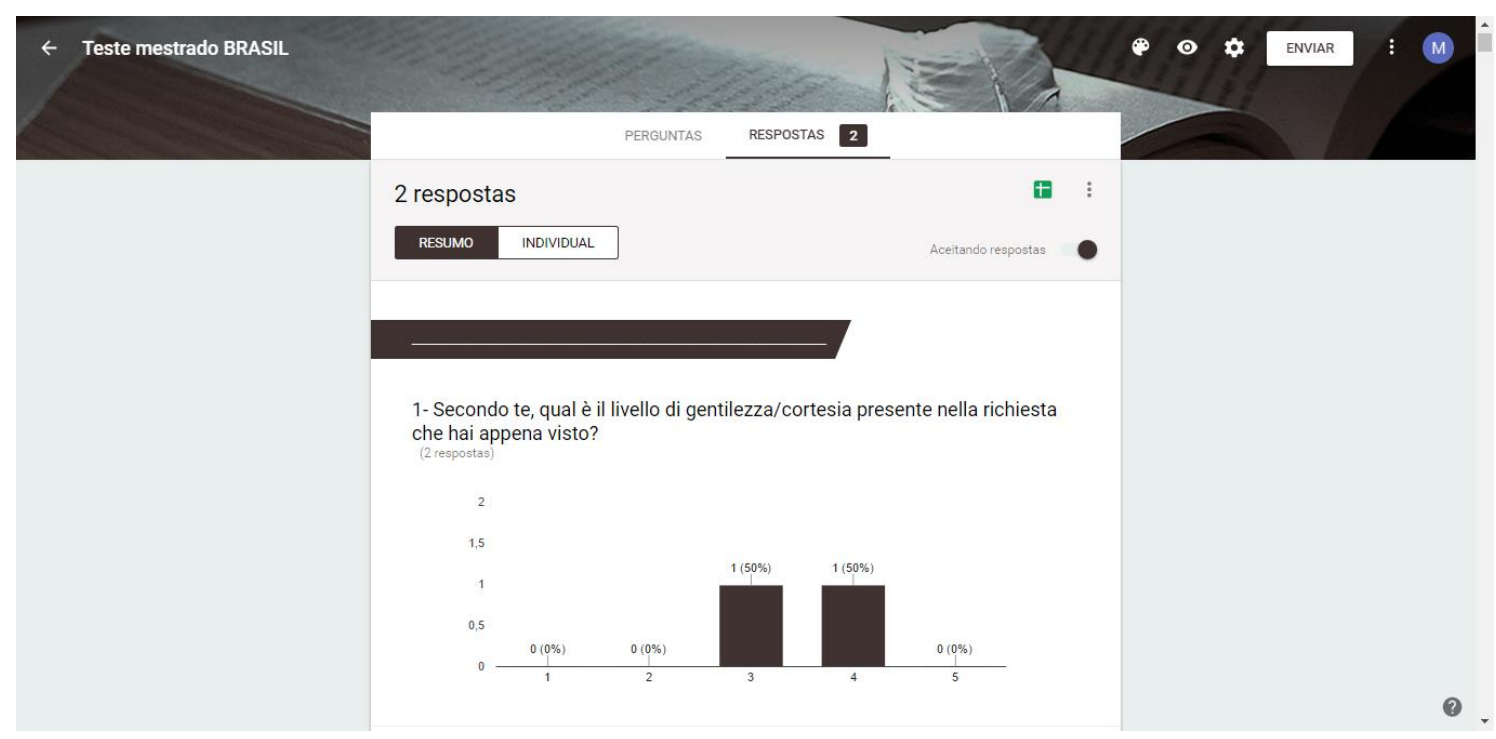

Figura 10 - Respostas resumidas Google Drive 


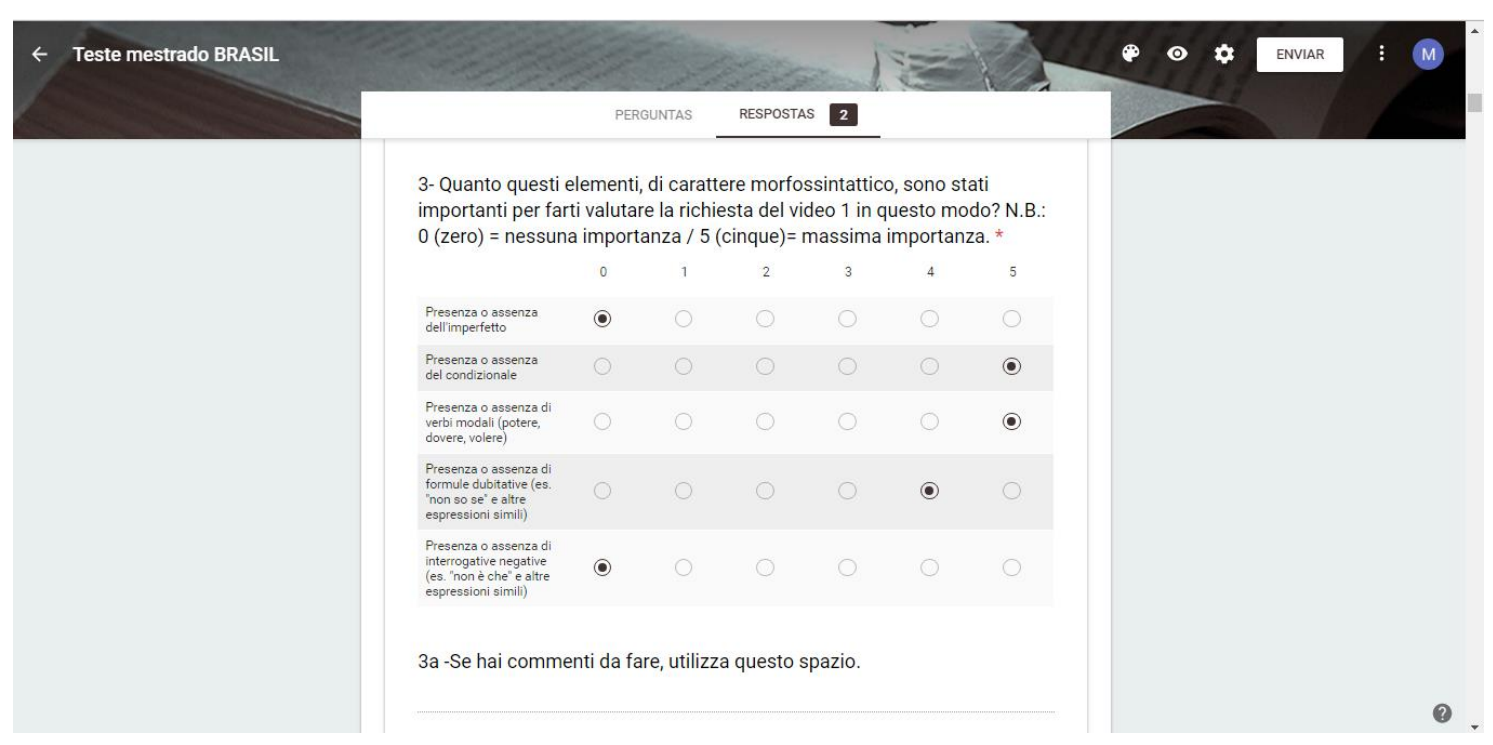

Figura 11 - Respostas individuais Google Drive

A possibilidade de visualizar as respostas em Excel, porém, é especialmente útil, pois possibilita a organização dos dados por meio de uma planilha, alterando eventualmente a ordem de colunas ou renomeando-as. Cada pergunta do questionário ocupa uma coluna, sendo que sua primeira linha é preenchida com o enunciado. No caso de perguntas de perguntas com grade de múltipla escolha como método de resposta, como as perguntas de número 2, cada linha da grade ocupa uma coluna. Por isso, na figura abaixo (em destaque), a primeira linha da planilha apresenta 8 colunas com a indicação de pergunta número 2 (o item dois, de fato, apresenta 8 categorias para as quais devem ser atribuídos um grau de importância na seleção do nível de cortesia).

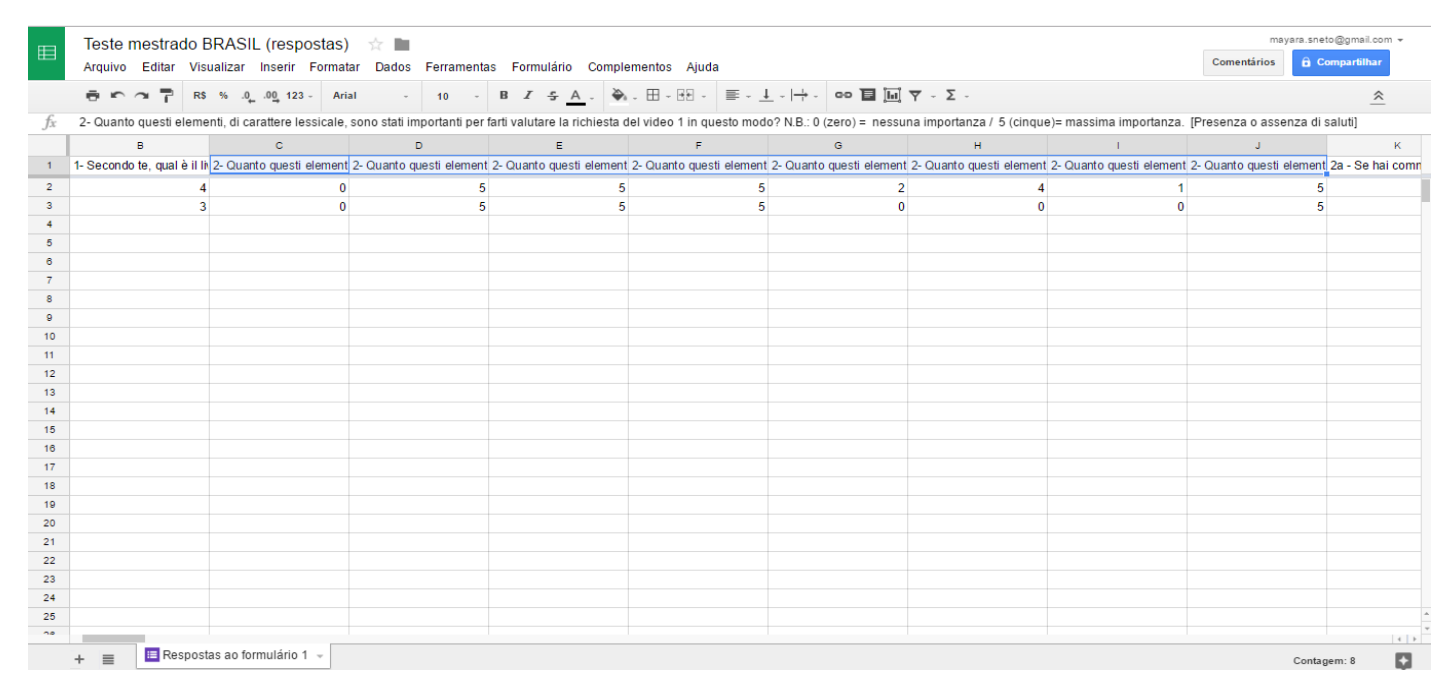

Figura 12 - Respostas em Excel Google Drive 
Durante os testes piloto, nenhum informante utilizou os campos de resposta aberta, que constam nos questionários para as perguntas 2 e 3, destinados a observações sobre as perguntas em questão. Entretanto, se algum informante desejasse fazer algum comentário, ele seria reportado na coluna e célula destinadas a isso no Excel (ver figura abaixo).

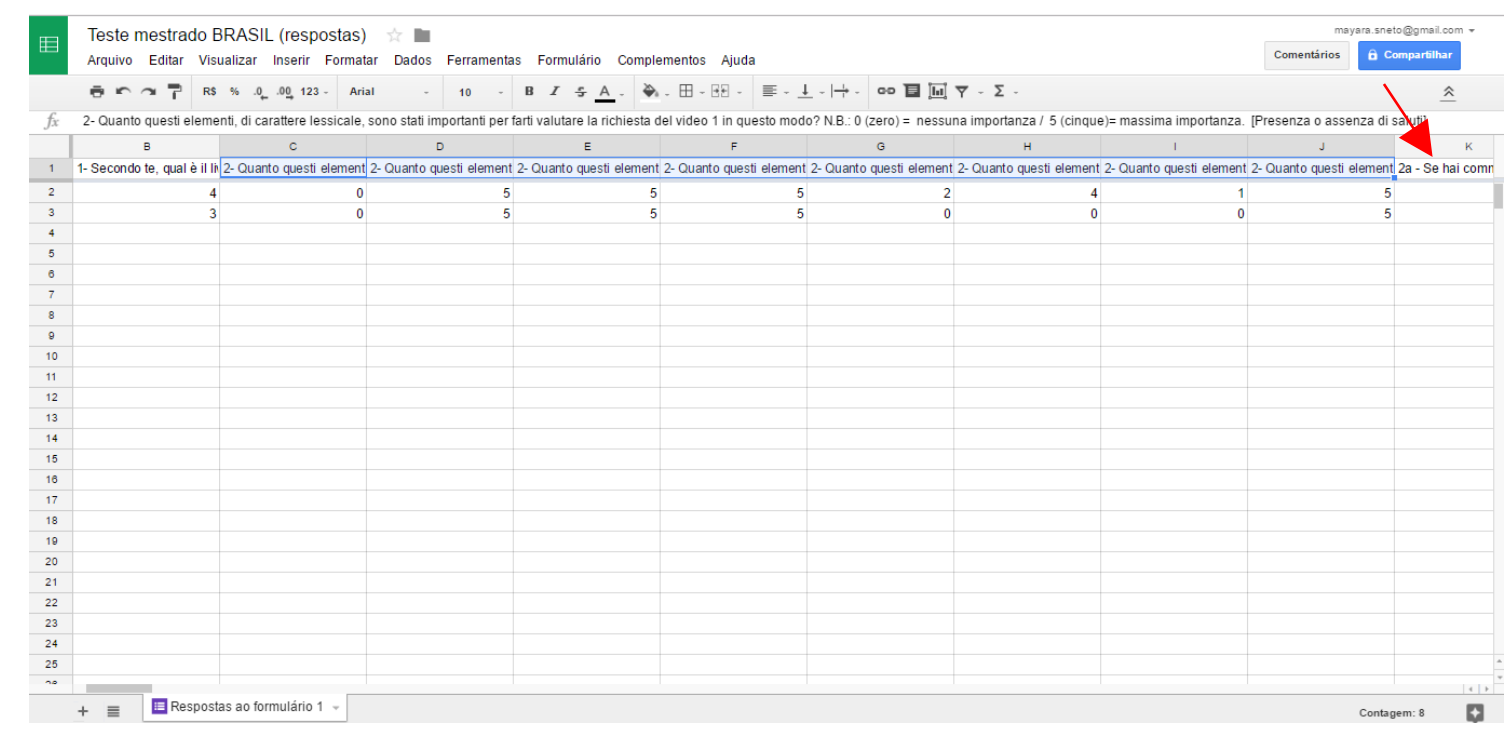

Figura 13 - Coluna/célula para comentário escrito opcional

\subsection{Tamanho da amostra, perfil dos informantes e coleta dos dados}

Segundo Dörnyei e Csizér (2012), de um ponto de vista puramente estatístico, o requisito básico para definir quantos informantes devem compor um corpus é que o resultado obtido a partir da amostra tenha uma "distribuição normal" (grosso modo, ainda que se trate de eventos aleatórios, ou respostas que partem de indivíduos diversos, uma amostra deve ter resultados que se concentrem tendencialmente em uma determinada alternativa ou nível de cortesia, por exemplo) e a condição para alcançar este objetivo, de acordo com Hatch e Lazaraton (1991), é que a amostra seja composta por 30 ou mais pessoas. Entretanto, há procedimentos estatísticos especiais que podem compensar amostras menores (Dörnyei, 2007). Ainda falando em estatística, é importante ter informantes suficientes para que os resultados sejam significativos. Uma vez que nos estudos em aquisição de L2 geralmente o coeficiente de correlação (a intensidade da associação linear existente entre as variáveis estudadas) está geralmente entre 0.30 e 0.40 , o ideal seria ter pelo menos 50 informantes. De qualquer maneira, partimos do que afirmaram Hatch e Lazaraton (1991) e decidimos obter ao menos 30 
informantes em cada grupo (brasileiros e italianos), o que seria uma espécie de "regra de ouro" para viabilizar análises estatísticas.

Quanto ao perfil dos informantes, no caso dos italianos, pela facilidade de contato e acesso, decidimos consultar principalmente estudantes universitários, o que significa que a maioria dos informantes estaria em uma faixa etária entre 18 e 35 anos, aproximadamente. Não estabelecemos os cursos de origem desses informantes (nem a universidade em que estudam), de modo a ter a oportunidade de consultar indivíduos que não necessariamente estudam disciplinas humanísticas e, por conseguinte, possivelmente não considerariam com frequência aspectos relativos à língua que falam todos os dias, o que é algo positivo para os próprios informantes e para nós, que teríamos dados tendencialmente menos condicionados pelo contato com as teorias com as quais lidamos em nossa pesquisa. No que diz respeito ao local de origem dos informantes, procuramos obter a colaboração de indivíduos do norte, do centro e do sul do país. Vale dizer que, embora nosso foco tenha sido coletar dados entre estudantes universitários, visto que alguns informantes se comprometeram a encontrar outras pessoas que colaborassem com a pesquisa, também tivemos informantes fora dessa faixa etária e que não frequentam mais ou nunca frequentaram cursos universitários.

Também os informantes brasileiros aprendizes de língua italiana eram, principalmente, estudantes universitários, especialmente de cursos de Letras com habilitação em italiano. Optamos por coletar dados de estudantes da USP, sede onde se desenvolveu essa pesquisa, e de outras universidades localizadas no nordeste e no sul do país em que há o curso de Letras-italiano ou de italiano como língua estrangeira em seus Centros de Línguas, contatando professores que se dispuseram a divulgar o questionário entre seus alunos. Assim como ocorreu com os italianos, também entre os informantes brasileiros tivemos a colaboração de alguns indivíduos que não eram exatamente estudantes universitários: é o caso dos alunos de Centros de Línguas das universidades que, em alguns casos, estavam fora faixa etária de 18 a 35 anos. Essas características resultaram em uma amostra razoavelmente variada em termos de idade, ocupação e origem dos informantes.

É importante dizer que, geralmente, o questionário que utilizamos para a coleta dos dados foi enviado por e-mail ou redes sociais a grupos de pessoas e não diretamente a indivíduos, de modo que não tivemos controle sobre variáveis como gênero e idade: nos grupos que recebiam o pedido de colaborar com a pesquisa, a adesão era opcional. A única exceção foram os alunos de uma turma do quarto semestre de estudos de língua italiana do curso de Letras-italiano da USP, que foram particularmente incentivados a colaborar com a pesquisa, 
também como um modo de refletir sobre aspectos pragmáticos ligados à realização dos pedidos em italiano e à percepção da cortesia presente nesse ato de fala, realizado justamente na língua em que estão se especializando.

A seguir, apresentamos em detalhes os perfis dos informantes dos quais coletamos os dados necessários à realização de nossa pesquisa.

Ao todo, contamos com a colaboração de 91 informantes: 40 brasileiros e 51 italianos. Isso significa que nossas duas amostras são válidas do ponto de vista estatístico, levando em conta que a condição para isso era ter, no mínimo, 30 informantes, conforme Dörnyei e Csizér (2012).

No grupo dos brasileiros, doravante BR, 32 indivíduos são mulheres e 8 são homens. Entre os italianos, doravante IT, 36 são mulheres e 15 são homens. Como foi possível notar, a distribuição da variável "gênero" não foi equilibrada em nossas amostras, isso porque, como dissemos anteriormente, não exercemos controle sobre ela no momento da coleta dos dados: os indivíduos dos grupos convidados a colaborar com a pesquisa poderiam optar por fazê-lo ou não (com exceção dos alunos da USP) e, coincidentemente, em ambos os grupos, as mulheres contribuíram mais significativamente.

\begin{tabular}{|l|c|c|c|c|}
\hline & \multicolumn{2}{|c|}{ Brasileiros } & \multicolumn{2}{c|}{ Italianos } \\
\hline Mulheres & 32 & $35 \%$ & 36 & $40 \%$ \\
\hline Homens & 8 & $9 \%$ & 15 & $16 \%$ \\
\hline $\begin{array}{l}\text { Total de } \\
\text { indivíduos por } \\
\text { grupo }\end{array}$ & 40 & $44 \%$ & 51 & $56 \%$ \\
\hline Total da amostra & \multicolumn{4}{|c|}{$91-100 \%$} \\
\hline
\end{tabular}

Tabela 9 - Distribuição do gênero nos grupos BR e IT

A média de idade de toda a amostra é de 32,6 anos, enquanto a mediana, isto é, o valor que ocupa a posição central do conjunto de dados que indicam a idade dos informantes, é 28 anos. A moda, valor com maior número de ocorrências em nosso corpus, é igual a 27: isso significa que entre os 91 informantes brasileiros e italianos, a idade que mais se repetiu foi 27 anos. Analisando cada grupo individualmente, no entanto, os valores apresentam algumas diferenças. Levando em consideração os valores de média e mediana, nota-se que os brasileiros 
são um pouco mais jovens que os italianos: os primeiros têm média de idade de 30,6 anos, enquanto os italianos têm 34,2; a mediana do grupo BR é 26 anos e a do grupo IT 31. Ao avaliar a moda, a idade que mais repete em cada um dos grupos, as tendências se invertem: a idade mais frequente no grupo BR é 27 anos, no grupo IT essa idade é 20 anos. Observando os valores máximos e mínimos, vemos que o grupo IT apresenta o informante mais jovem, com 18 anos, e também o mais velho, com 65. O indivíduo mais jovem grupo BR tem 19 anos, enquanto o mais velho tem 58 .

\begin{tabular}{|c|c|c|c|}
\hline & $\begin{array}{c}\text { Brasileiros } \\
\text { (40 indivíduos) }\end{array}$ & $\begin{array}{c}\text { Italianos } \\
\text { (51 indivíduos) }\end{array}$ & Geral \\
\hline Média & 30,6 & 34,2 & 32,6 \\
\hline Mediana & 26 & 31 & 28 \\
\hline Moda & 27 & 20 & 27 \\
\hline
\end{tabular}

Tabela 10 - Idade dos informantes (média, mediana e moda)

Tanto para organizar a coleta dos dados quanto para descrevê-los, optamos por dividir as amostras por região. No grupo BR, os indivíduos que colaboraram com a pesquisa são do nordeste, sudeste e sul; no grupo IT, do norte, centro e sul.

São alunos da Universidade Federal do Ceará, e provenientes do estado homônimo, a quase totalidade dos dez informantes do nordeste do Brasil: são nove aqueles nascidos nesse estado, sendo seis da capital Fortaleza e três de cidades do interior (Morada Nova, Paraipaba e Maracanaú). Desses nove informantes, apenas dois não residem em Fortaleza, mas em Caucaia. A única informante não proveniente do Ceará é de Canavieiras, na Bahia, mas reside em São Paulo e é aluna da USP.

Entre os dezoito informantes brasileiros do sudeste, todos do estado de São Paulo, doze nasceram e residem na capital e cinco nasceram em cidades do interior (Jacareí, Taubaté, Votorantim, Santa Bárbara d'Oeste e São José dos Campos), mas também residem na capital. Apenas uma informante nasceu na cidade de São Paulo e reside em outro estado e região (Curitiba, Paraná). Os informantes do sudeste, com exceção da informante paulistana que reside em Curitiba (e é aluna da Universidade Federal do Paraná - UFPR), são alunos do curso de Letras-italiano da USP. 
Os doze informantes do sul são oriundos de dois estados. Do Rio Grande do Sul são nove, sendo cinco da capital Porto Alegre e quatro de outras cidades (Guabiju, Bento Gonçalves, Encantado e Santa Cruz do Sul). Seis deles residem em Porto Alegre, enquanto dois residem em Bento Gonçalves e um em Gravataí. Completando o grupo do sul do Brasil, temos três informantes do estado do Paraná: dois nasceram em Curitiba, dos quais um reside na mesma cidade e outro em São José dos Pinhais, e o terceiro nasceu em Guaratuba, mas reside em Curitiba. Os informantes do Rio Grande do Sul são alunos da Universidade Federal do Rio Grande do Sul no âmbito da habilitação em Letras-italiano ou do Núcleo de Ensino de Línguas em Extensão (NELE) da universidade, enquanto aqueles do Paraná são alunos do curso de Letras-italiano da UFPR.

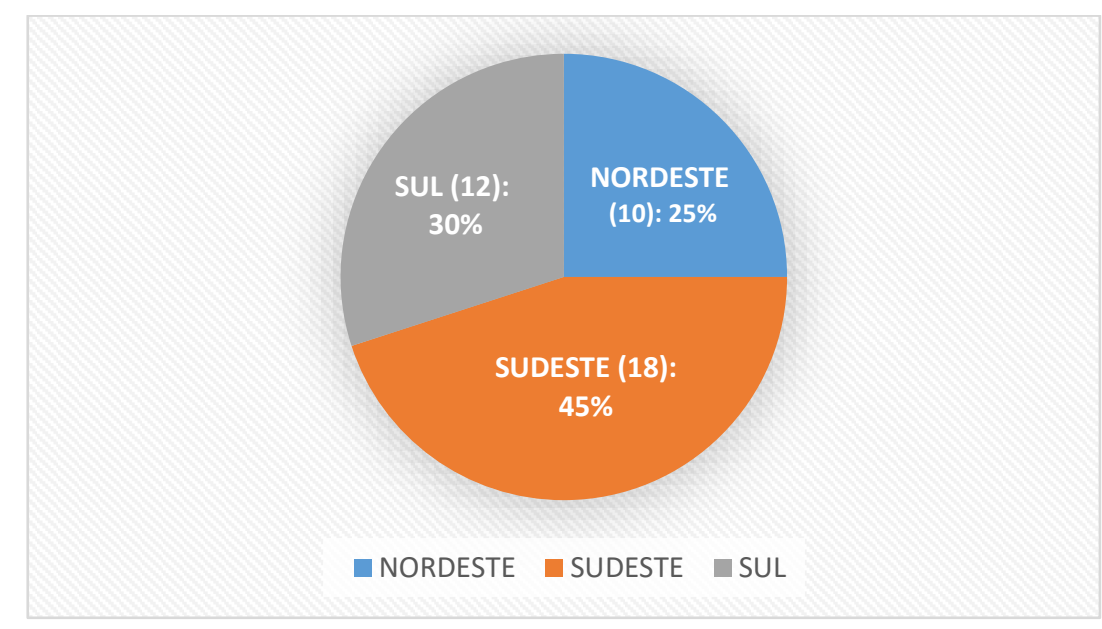

Gráfico 1 - Origem dos informantes brasileiros

No grupo IT, os informantes do norte são, majoritariamente, do Veneto e da Lombardia. Dos 16 indivíduos, 12 são vênetos, sendo oito de Padova, dois de Treviso, um de Verona e um de Este. Os três lombardos são de Brescia, Milano e Como. Completando o grupo, há um único informante de Pordenone (região Friuli-Venezia-Giulia). Apenas três dos dezesseis informantes não residem na mesma cidade de nascimento: o informante de Este reside em Santa Margherita d'Adige (ambas cidades da província de Padova - Veneto), um dos que nasceram em Padova reside em Campo San Martino (também na província de Padova) e a informante de Pordenone reside em Venezia. Como havíamos dito anteriormente, não definimos os cursos nem a universidade de origem dos informantes italianos, de modo que esse aspecto dos dados apresenta muita variação e, ao contrário do que foi feito com os informantes brasileiros, não 
serão reportados em relação aos informantes em particular, mas de uma maneira mais geral nos parágrafos dedicados à escolaridade dos grupos BR e IT.

Os informantes do centro da Itália são 23, sendo os mais numerosos da amostra, e têm origem bastante variada. Quatro são do Abruzzo (de Atessa, Castel di Sangro, L’Aquila e Teramo), sete são do Lazio (um de Latina e seis de Roma), três da região Marche (Ancona, San Benedetto del Tronto e Sant'Elpidio a Mare), oito da Toscana (dois de Firenze, dois de Vinci e um de cada uma das seguintes cidades: Bibbiena, Empoli, Pontedera e Ravenna) e um da Umbria (Orvieto). Em geral, se não na mesma cidade de nascimento, os informantes desse subgrupo residem em localidades dentro na mesma região ${ }^{21}$. As exceções são duas informantes que saíram do centro e se transferiram para o nordeste da Itália (a informante de Atessa/Abruzzo reside em Padova/Veneto, a informante de Bibbiena/Toscana reside em Monfalcone/FriuliVenezia-Giulia e uma permaneceu no centro da Itália, mas mudou de região, indo de L'Aquila/Marche para Roma/Lazio).

O subgrupo do sul da Itália é composto por 12 informantes e, embora tenhamos representantes de diversas regiões, mais da metade deles é da Puglia: dois de Lecce e um de cada uma das seguintes das cidades: Bari, Galatina, Nardò, Noci e Taranto, totalizando sete indivíduos. Os cinco restantes são das seguintes cidades/regiões: Catanzaro/Calabria, Napoli/Campania, Agnone/Molise, Lanusei/Sardegna e Palermo/Sicilia. Metade dos informantes (seis) desse grupo não reside nas cidades de nascimento: a informante de Agnone reside em Rosello (Abruzzo), as de Catanzaro e Lanusei residem em Roma (Lazio), a de Taranto reside em Padova (Veneto), o de Noci reside em Alberobello (Puglia) e a de Galatina em Lecce (Puglia) sendo esses dois últimos os únicos a não mudar de região.

\footnotetext{
${ }^{21} \mathrm{Na}$ Itália, o que é chamado de região equivale aos nossos estados.
} 


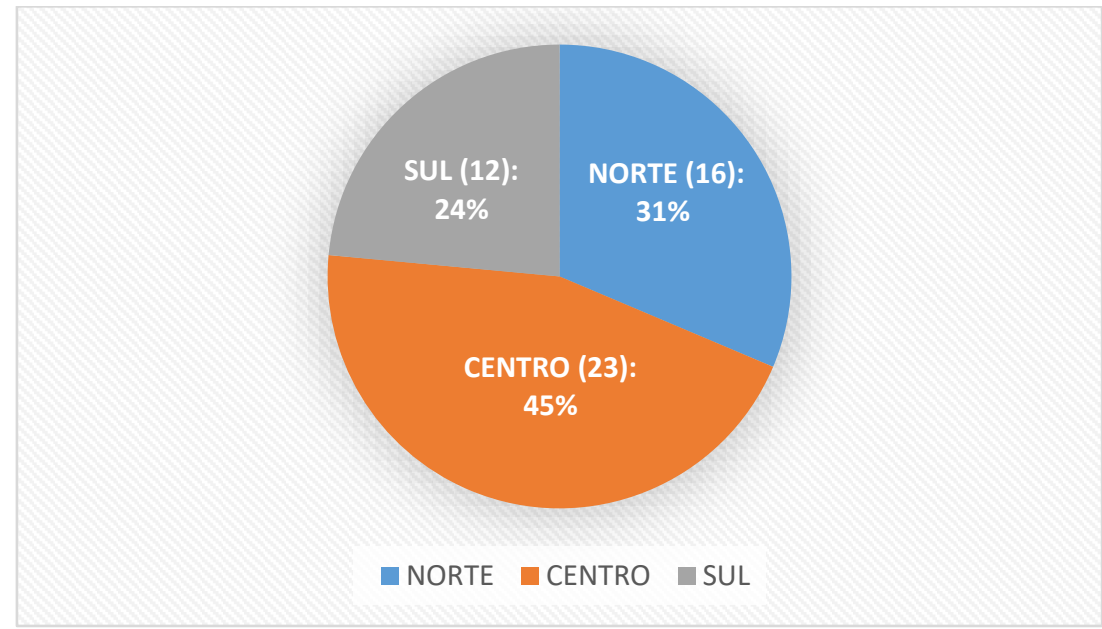

Gráfico 2 - Origem dos informantes italianos

Quanto à escolaridade dos informantes, 21 indivíduos do grupo BR declararam ter ensino superior incompleto (em curso), o que é consequência natural do perfil de que consultamos: estudantes universitários. O segundo perfil mais numeroso, com nove indivíduos, é o de pessoas com ensino superior completo e entre eles estão informantes formados em Letras, mas também em Direito, História e Sistemas de Informação. Os dez outros informantes estão distribuídos em outros níveis de formação, como é possível visualizar no gráfico a seguir.

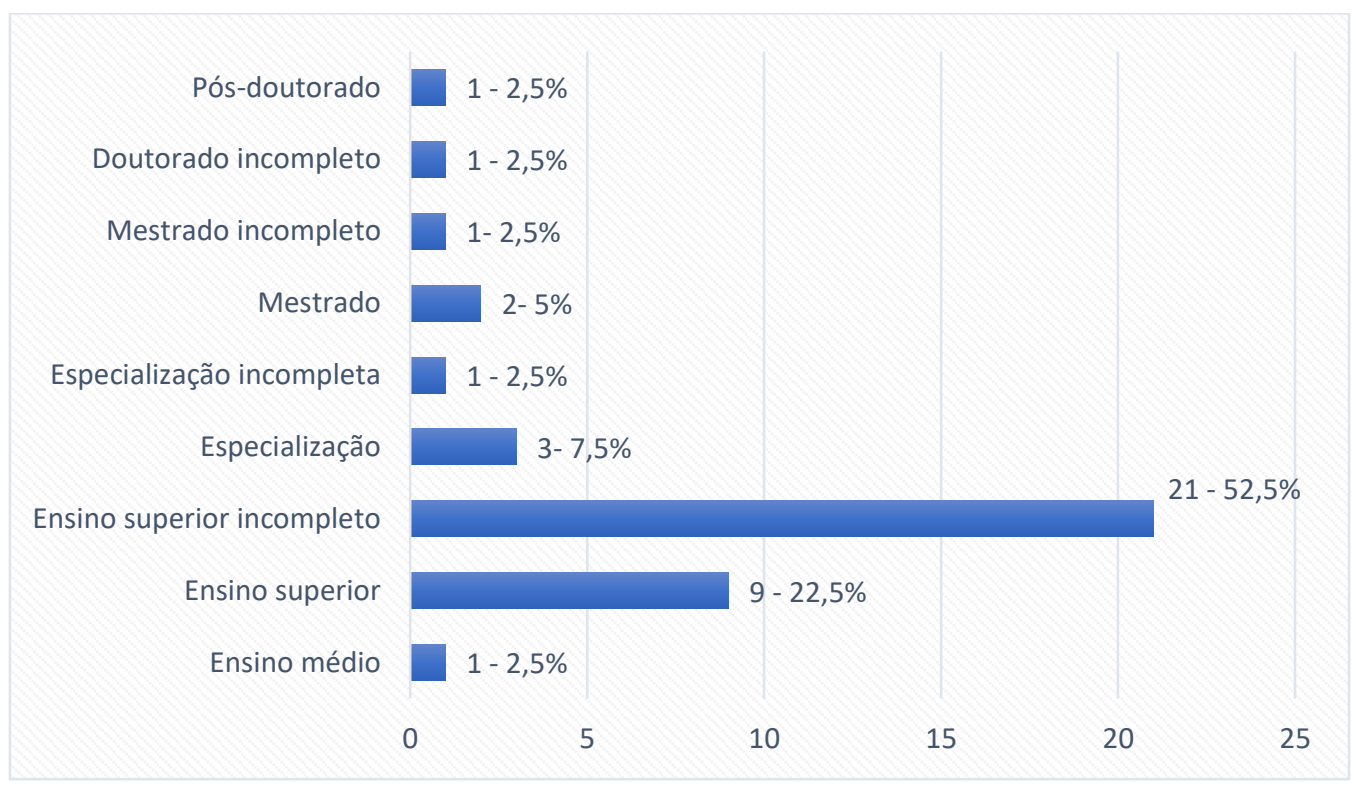

Gráfico 3 - Escolaridade dos informantes brasileiros 
No grupo IT, temos números muito próximos para três níveis de formação: ensino superior, com 11 indivíduos; ensino médio, com dez indivíduos; e ensino superior incompleto (em curso), com nove indivíduos. Os 21 informantes restantes estão distribuídos em outros níveis de formação, visualizáveis no gráfico 4. Quanto à área de formação daqueles com ensino superior completo, temos cursos como Direito, Economia, Farmácia, Jornalismo, Letras, Pedagogia e Serviço Social. Entre os que ainda estão cursando o ensino superior, há graduandos em Informática, Letras, Línguas e Mediação Linguística, Química Industrial e Turismo.

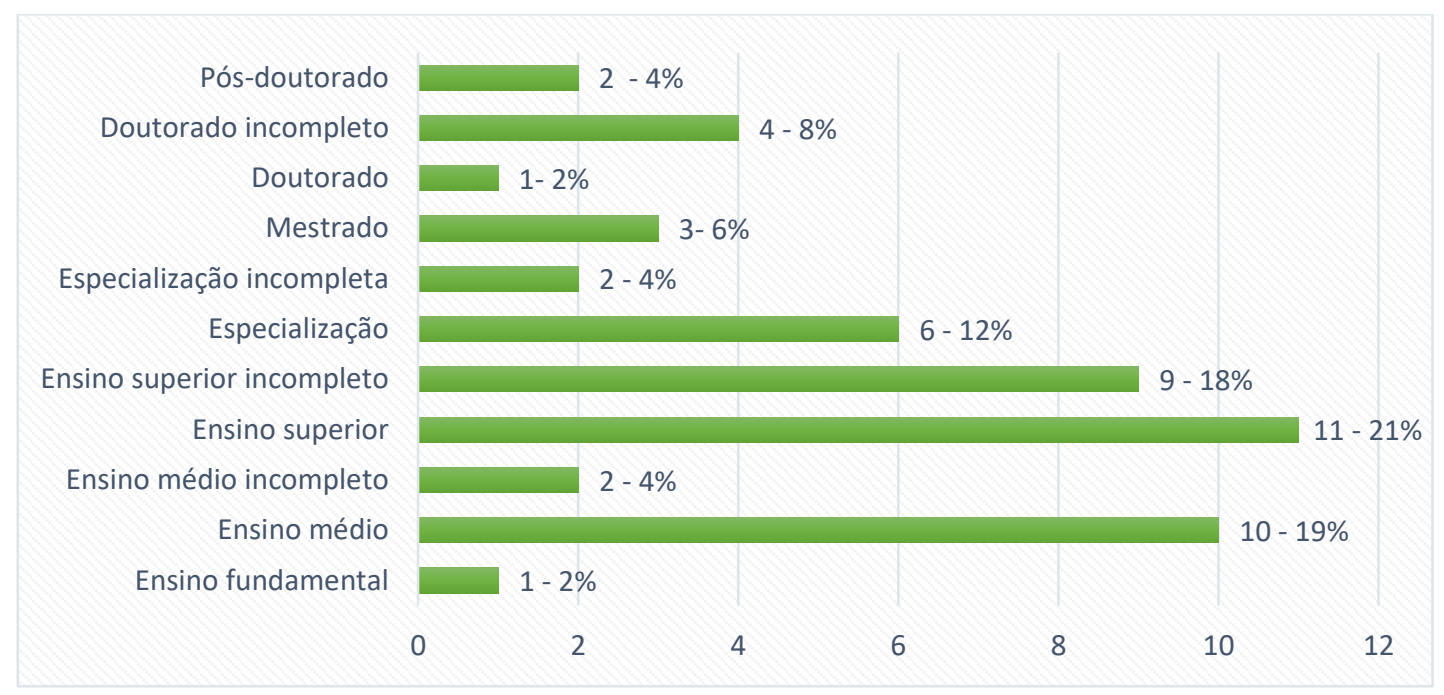

Gráfico 4 - Escolaridade dos informantes italianos

\subsection{Formas de análise dos dados}

Após a coleta de dados de informantes brasileiros e italianos, organizamos as informações em planilhas de Excel, de modo a facilitar sua visualização. Por meio do Excel, foi possível observar de maneira organizada tanto os dados relativos ao perfil sociolinguístico dos informantes (que já apresentamos) quanto a quantidade de vezes em que cada um dos níveis de cortesia e cada categoria que se mostrou determinante para a seleção desses níveis foram assinaladas. Os dados relativos aos níveis de cortesia serão, inicialmente, apresentados por meio de uma tabela com os números totais, a fim de que seja possível visualizar quantas vezes cada nível de cortesia foi selecionado por cada grupo de informante em cada um dos vídeos/pedidos avaliados. Utilizando o software SPSS (Statistical Package for the Social Sciences - V.20 IBM - USA), aplicamos a esses dados o teste ANOVA (Analysis of Variance, Análise das Variâncias) de uma via, que calcula a diferença entre os grupos no que diz respeito aos níveis de cortesia. 
O passo sucessivo, utilizando o mesmo SPSS, foi aplicar uma regressão linear ${ }^{22}$ da variável dependente "cortesia", controlada pelos vídeos (variáveis independentes), de modo a verificar de que maneira cada uma das 19 variáveis dependentes distribuídas entre as perguntas 2 e 8 dos questionários se relacionam com os níveis de cortesia atribuídos a cada um dos vídeos.

O resultado dos testes realizados com o modelo ANOVA serão apresentados por meio de tabelas e as informações necessárias à compreensão dos dados nelas presentes serão dadas ao longo do próprio capítulo dedicado à análise dos resultados.

\footnotetext{
${ }^{22}$ Estudo da relação entre uma variável dependente e variáveis independentes.
} 


\section{Análise e discussão dos dados}

Nesta seção, serão descritos os dados relativos aos níveis de cortesia atribuídos aos pedidos. Começaremos ilustrando o número de ocorrências, relacionando os oito vídeos utilizados na pesquisa com os diferentes graus de cortesia; em seguida, faremos observações a partir das médias totais e por grupo; finalmente, veremos os mesmos dados com os resultados obtidos a partir do tratamento estatístico realizado com a ANOVA. Encerrada essa primeira etapa, partiremos das análises estatísticas realizadas para verificar de que maneira as variáveis apresentadas aos informantes como possível influência para a percepção da cortesia podem se relacionar com o nível de cortesia efetivamente atribuído a cada um dos pedidos analisados.

Antes de iniciar a análise, apenas para facilitar o entendimento dos dados, recapitulamos a seguir as características de cada um dos oito vídeos que utilizamos e apresentamos o modo com que serão nominados durante a análise (coluna “identificação"):

\begin{tabular}{|c|c|c|c|c|}
\hline Vídeo & Pedido/setting & Grau de imposição & Grau de familiaridade & Identificação \\
\hline 1 & caneta - rua & baixo & médio-alto (6-10) & caneta + \\
\hline 2 & caneta - rua & baixo & médio-baixo (0-5) & caneta - \\
\hline 3 & celular - rua & alto & médio-alto (6-10) & celular + \\
\hline 4 & celular - rua & alto & médio-baixo (0-5) & celular - \\
\hline 5 & água - casa & baixo & médio-alto (6-10) & água + \\
\hline 6 & água - casa & baixo & médio-baixo (0-5) & água - \\
\hline 7 & $\begin{array}{c}\text { roupas/banho - } \\
\text { casa }\end{array}$ & alto & médio-alto (6-10) & temporal + \\
\hline 8 & $\begin{array}{c}\text { roupas/banho - } \\
\text { casa }\end{array}$ & alto & médio-baixo (0-5) & temporal - \\
\hline
\end{tabular}

Tabela 11 - Dados dos vídeos e respectivas identificações 


\subsection{Níveis de cortesia}

\section{- Número de informantes por nível de cortesia}

A primeira informação solicitada aos informantes da pesquisa após a visualização de cada vídeo - e, portanto, de cada pedido - foi o nível de cortesia a eles atribuído (em escala de 1 a 5). Para apresentar os resultados relativos a esse dado, será utilizada a tabela a seguir, elaborada a partir das indicações obtidas nos questionários online. Na tabela é possível visualizar os dados brutos, isto é, que resultaram apenas da verificação de quantas vezes cada nível de cortesia foi selecionado pelos informantes brasileiros e italianos ao avaliar os oito pedidos.

\begin{tabular}{|l|c|c|c|c|c|c|c|c|c|c|}
\hline \multirow{4}{*}{} & \multicolumn{5}{|c|}{ Brasileiros } & \multicolumn{5}{c|}{ Italianos } \\
\cline { 2 - 11 } & \multicolumn{4}{|c|}{ Níveis de cortesia de cortesia } \\
\cline { 2 - 11 } & 1 & 2 & 3 & 4 & 5 & 1 & 2 & 3 & 4 & 5 \\
\hline Vídeo 1 & 0 & 3 & 7 & $\mathbf{1 9}$ & 11 & 0 & 3 & 15 & $\mathbf{1 9}$ & 14 \\
Vídeo 2 & 1 & 8 & $\mathbf{1 4}$ & 13 & 4 & 1 & 3 & $\mathbf{2 0}$ & 18 & 9 \\
Vídeo 3 & 1 & 6 & 12 & $\mathbf{1 4}$ & 7 & 3 & 17 & $\mathbf{2 1}$ & 9 & 1 \\
Vídeo 4 & 0 & 1 & 4 & 12 & $\mathbf{2 3}$ & 2 & 7 & 10 & 12 & $\mathbf{2 0}$ \\
Vídeo 5 & 0 & 2 & 11 & 11 & $\mathbf{1 6}$ & 1 & 9 & $\mathbf{1 7}$ & 14 & 10 \\
Vídeo 6 & 0 & 3 & 7 & 13 & $\mathbf{1 7}$ & 2 & 6 & $\mathbf{1 6}$ & 15 & 12 \\
Vídeo 7 & 3 & $\mathbf{1 5}$ & $\mathbf{1 5}$ & 7 & 0 & 7 & 15 & $\mathbf{1 7}$ & 7 & 5 \\
Vídeo 8 & 0 & 1 & 5 & 15 & $\mathbf{1 9}$ & 0 & 3 & 10 & 18 & $\mathbf{2 0}$ \\
\hline
\end{tabular}

Tabela 12 - Níveis de cortesia atribuídos por BR e IT a todos os vídeos

Observando os dados da tabela acima, vê-se que para os vídeos 1, 2, 4, 7 e 8 as percepções dos dois grupos parecem ser análogas, visto que, embora houvesse cinco opções (1 a 5) na escala utilizada para medir a percepção da cortesia, os informantes brasileiros e italianos concentraram suas respostas nos mesmos níveis.

Para o pedido caneta + , ambos os grupos selecionaram mais vezes o nível 4 (médio-alto). No caso do vídeo que continha o pedido caneta -, o nível mais selecionado foi o 3 (médio). Ao pedido celular - foi atribuída mais vezes a avaliação mais alta (nível 5). Os pedidos temporal + e temporal - tiveram, respectivamente, níveis de cortesia 3 (médio) e 5 (alto). Em todos os casos em que houve essa coincidência (cinco dos oito vídeos), os níveis de cortesia mais selecionados vão de 3 a 5 . Isso indicaria que, além de as avaliações serem muito 
semelhantes, elas tendem a ser positivas, havendo um número baixo de ocorrências nos primeiros dois níveis.

Outro fato a se notar a partir desse levantamento numérico inicial é que ao menos um dos níveis adjacentes àquele mais selecionado também foi escolhido um número considerável de vezes e, na maioria dos casos, esse nível adjacente está entre o médio e o alto. Tomemos como exemplo o vídeo caneta - : brasileiros e italianos escolheram mais vezes o nível 3, mas o segundo nível mais selecionado, por ambos os grupos, foi o 4. Entre os vídeos que apresentaram resultados semelhantes, vale a pena comentar o caso do vídeo temporal $+: \mathrm{o}$ nível escolhido mais vezes foi o 3, mas esse foi o único para o qual ambos os grupos também selecionaram por um número considerável de vezes o nível 2. O pedido presente no vídeo temporal + , portanto, com base na observação dos dados iniciais, pareceria ser aquele com avaliação mais negativa entre todos aqueles apresentados aos informantes.

Ainda observando os dados iniciais, vejamos os casos em que houve diferença na percepção de BR e IT. Para o vídeo celular + , o grupo de brasileiros atribuiu mais vezes o nível de cortesia 4 (médio-alto) e o IT o nível 3 (médio); para os vídeos água + e água - , o nível indicado mais vezes por brasileiros foi 5 (alto), enquanto italianos indicaram o 3 (médio). Nos três casos em que houve disparidade, portanto, nota-se que brasileiros tenderam a avaliar os pedidos de modo mais positivo que os italianos.

Assim como ocorreu com os vídeos que apresentaram semelhanças quanto aos resultados ligados à percepção da cortesia, também para aqueles com percepções diversas um dos níveis adjacentes aos mais selecionados foi escolhido um número elevado de vezes: para os vídeos 5 e 6, o segundo nível mais selecionado foi o 4 (médio-alto), enquanto para o vídeo 3 foram os níveis foi o 3 (médio) para BR e 2 (médio-baixo) para IT.

\section{- Médias totais e por grupo}

Observar os dados iniciais relativos à percepção da cortesia presente nos pedidos nos permitiu depreender algumas informações iniciais sobre essa variável. Contudo, podemos complementar essa primeira observação utilizando as médias gerais e por grupo dos níveis de cortesia atribuídos por brasileiros e italianos a cada um dos pedidos. Na tabela a seguir, são apresentados os resultados com as médias dos níveis de cortesia para os oito vídeos, bem como 
dados sobre desvio padrão (DP), que diz respeito à medida da variação dos dados em relação à média, e erro padrão (EP), que representa uma estimativa do desvio padrão de uma amostra.

Dados Descritivos

\begin{tabular}{|ll|r|r|r|r|}
\hline & & N & Média & \multicolumn{1}{c|}{ DP } & \multicolumn{1}{c|}{ EP } \\
\hline V1 & Brasil & 40 & 3,95 &, 876 &, 138 \\
& Italia & 51 & 3,86 &, 895 &, 125 \\
& Total & 91 & 3,90 &, 883 &, 093 \\
\hline V2 & Brasil & 40 & 3,28 &, 987 &, 156 \\
& Italia & 51 & 3,61 &, 918 &, 129 \\
& Total & 91 & 3,46 &, 958 &, 100 \\
\hline V3 & Brasil & 40 & 3,50 & 1,038 &, 164 \\
& Italia & 51 & 2,76 &, 885 &, 124 \\
& Total & 91 & 3,09 & 1,018 &, 107 \\
\hline V4 & Brasil & 40 & 4,43 &, 781 &, 123 \\
& Italia & 51 & 3,80 & 1,217 &, 170 \\
& Total & 91 & 4,08 & 1,088 &, 114 \\
\hline V5 & Brasil & 40 & 4,03 &, 947 &, 150 \\
& Italia & 51 & 3,45 & 1,064 &, 149 \\
& Total & 91 & 3,70 & 1,049 &, 110 \\
\hline V6 & Brasil & 40 & 4,10 &, 955 &, 151 \\
& Italia & 51 & 3,57 & 1,100 &, 154 \\
& Total & 91 & 3,80 & 1,067 &, 112 \\
\hline V7 & Brasil & 40 & 2,65 &, 864 &, 137 \\
& Italia & 51 & 2,76 & 1,159 &, 162 \\
& Total & 91 & 2,71 & 1,036 &, 109 \\
\hline V8 & Brasil & 40 & 4,30 &, 791 &, 125 \\
& Italia & 51 & 4,08 &, 913 &, 128 \\
& Total & 91 & 4,18 &, 864 &, 091 \\
\hline
\end{tabular}

Tabela 13 - Médias, DP e EP dos grupos BR e IT quanto aos níveis de cortesia

Com base nos valores das médias totais (coluna "Média"), notamos que para os vídeos caneta + e caneta - , celular + ,água + e água - , a média está na casa dos três pontos, isto é, tanto brasileiros quanto italianos atribuíram um nível de cortesia majoritariamente médio. No caso dos vídeos celular - e temporal - , ambos com alto grau de imposição e familiaridade médio-baixa, a média ficou acima de 4 pontos, o que indica, em geral, que eles conteriam um nível de cortesia médio-alto. O vídeo temporal + foi o único que apresentou média na casa dos dois pontos (nível médio-baixo de cortesia) confirmando o que havíamos notado a partir dos dados brutos em relação ao mesmo vídeo: trata-se daquele que recebeu a avaliação mais baixa. 
Um fato interessante é que nenhum dos vídeos/pedidos recebeu avaliação geral nem por grupo com média nos níveis contidos nos extremos da escala de avaliação (1 - baixo e 5 - alto).

Algo igualmente relevante é que, também considerando as médias totais, os pedidos que tiveram a melhor e a pior avaliação estão justamente entre aqueles que apresentaram semelhanças entre os grupos são do mesmo tipo, tendo apenas o grau de familiaridade diverso: trata-se do pedido de roupas secas ou banho. Tem a média mais alta (4,18 - nível médio alto de cortesia) o pedido temporal - . Para realizá-lo, a falante empregou uma quantidade considerável de modificadores: saudação, duvidador, atenuador, reforçador, verbo condicional, verbo modal, fórmula dubitativa, justificativa e agradecimento (ver tabela 8). Isso pode querer dizer que, de acordo com o parecer dos informantes brasileiros e italianos, quanto maior o grau de imposição e menor o grau de familiaridade entre os falantes, o ideal é atenuar tanto quanto possível a força ilocucionária do pedido, de modo a salvaguardar a face de ambos os falantes (usando a lógica proposta por Brown e Levinson, 1987) e parecer mais cortês, utilizando para isso modificadores tanto internos quanto externos.

O vídeo que teve a pior avaliação geral foi o de temporal + , também com um pedido de roupas secas ou banho, com média de 2,71 (nível médio-baixo de cortesia). A falante que realizou o ato de fala em questão utilizou uma saudação, um reforçador e uma justificativa, um número bem menor de modificadores em comparação àquele que foi mais bem avaliado pelos informantes dos dois grupos. O grau de familiaridade entre as falantes do vídeo em questão era médio-alto, mas isso não impediu que os informantes interpretassem de maneira razoavelmente negativa o uso de poucos mecanismos de atenuação.

Se considerarmos, por outro lado, as médias de cada um dos grupos para verificar quais pedidos receberam as avaliações mais altas e baixas, veremos que, para os brasileiros, o mais cortês seria o celular -, com média de 4,43, e o mais descortês o do temporal + , com média de 2,65. Para os italianos, o pedido mais cortês seria o temporal -, com média de 4,08, e os mais descorteses são dois: celular + e temporal + , com médias de 2,76. Assim, tanto para brasileiros quanto para italianos, foram pedidos com alto grau de imposição e grau de familiaridade médio-baixo aqueles mais bem avaliados, enquanto aqueles com avaliação mais baixa também possuem alto grau de imposição, mas familiaridade médio-alta. Um fato interessante é que nenhum dos vídeos/pedidos recebeu avaliação geral nem por grupo com média nos níveis contidos nos extremos da escala de avaliação: 1 (baixo) e 5 (alto). 
Ainda discutindo as médias relativas aos grupos BR e IT, vemos que os valores ficaram em níveis diferentes no caso dos seguintes pedidos:

- celular +, para o qual brasileiros tem média 3,50 (nível de cortesia médio) e italianos 2,76 (nível médio-baixo);

- celular-, com média dos brasileiros igual a 4,43 e de italianos a 3,80;

- água +, brasileiros 4,03 e italianos 3,43; e

- água -, para o qual a média dos brasileiros foi de 4,10 e a dos italianos de 3,57.

A diferença em relação aos dados brutos é que o vídeo celular - apresentou médias diferentes e, por isso, percepções diferentes, embora o nível de cortesia mais selecionado tenha sido o mesmo para BR e IT: 5 (alto). Isso pode ser justificado pelo fato de os níveis 4 e 3 também terem tido uma quantidade razoável de seleções no caso dos informantes italianos. Se calcularmos a diferença de médias entre os grupos (tabela 13), podemos ver que se confirma a disparidade entre BR e IT vista nos resultados relativos aos vídeos celular + , celular -, água + e água - : ainda que a diferença de valores referentes às médias por grupo seja inferior a um ponto, em comparação com os restantes, ela pode ser considerada relevante. Note-se que o vídeo com médias (percepções) mais próximas é o de número 1 e aquele com médias mais distantes o de número 3.

\begin{tabular}{|c|c|}
\hline Vídeos & $\begin{array}{c}\text { Diferença de médias entre } \\
\text { grupos BR e IT }\end{array}$ \\
\hline V1 & 0,09 \\
\hline V2 & 0,33 \\
\hline V3 & 0,74 \\
\hline V4 & 0,63 \\
\hline V5 & 0,58 \\
\hline V6 & 0,53 \\
\hline V7 & 0,11 \\
\hline V8 & 0,22 \\
\hline
\end{tabular}

Tabela 14 - Diferença de médias dos grupos BR e IT quanto aos níveis de cortesia 
Para concluir a análise dos resultados ligados à percepção da cortesia com dados mais acurados, passemos agora ao que nos dizem os dados do teste ANOVA, por meio do qual obtivemos informações sobre a diferença entre os grupos no que diz respeito aos níveis de cortesia. Para esse tipo de teste, o nível de significância/confiança estabelecido é de $95 \%$, portanto, pode haver, no máximo, $5 \%$ de chance de o resultado ser devido ao acaso. Sendo assim, para que os valores que observaremos na última coluna da tabela a seguir (Sig.) sejam significantes, eles devem ser sempre menores que 0,05 $(<0,05)$. Os dados presentes em "Soma dos quadrados", "Graus de Liberdade", "Média quadrados" e "F" são ligados ao cálculo realizado no contexto da análise das variâncias (ANOVA).

\begin{tabular}{|c|c|c|c|c|c|c|}
\hline \multicolumn{7}{|c|}{ Análise das variâncias (ANOVA) } \\
\hline \multicolumn{2}{|c|}{ Vídeos } & $\begin{array}{c}\text { Soma } \\
\text { quadrados }\end{array}$ & $\mathrm{GL}$ & $\begin{array}{c}\text { Média } \\
\text { quadrados }\end{array}$ & $\mathrm{F}$ & Sig. \\
\hline \multirow[t]{3}{*}{ V1 } & Entre Grupos & ,171 & 1 & , 171 & 217 &, 642 \\
\hline & Intra Grupos & 69,939 & 89 &, 786 & & \\
\hline & Total & 70,110 & 90 & & & \\
\hline \multirow[t]{3}{*}{$\mathrm{V} 2$} & Entre Grupos & 2,484 & 1 & 2,484 & 2,758 &, 100 \\
\hline & Intra Grupos & 80,132 & 89 &, 900 & & \\
\hline & Total & 82,615 & 90 & & & \\
\hline \multirow[t]{3}{*}{ V3 } & Entre Grupos & 12,120 & 1 & 12,120 & 13,288 & ,000 \\
\hline & Intra Grupos & 81,176 & 89 &, 912 & & \\
\hline & Total & 93,297 & 90 & & & \\
\hline \multirow[t]{3}{*}{ V4 } & Entre Grupos & 8,647 & 1 & 8,647 & 7,868 & ,006 \\
\hline & Intra Grupos & 97,814 & 89 & 1,099 & & \\
\hline & Total & 106,462 & 90 & & & \\
\hline \multirow[t]{3}{*}{ V5 } & Entre Grupos & 7,387 & 1 & 7,387 & 7,177 & ,009 \\
\hline & Intra Grupos & 91,602 & 89 & 1,029 & & \\
\hline & Total & 98,989 & 90 & & & \\
\hline \multirow[t]{3}{*}{ V6 } & Entre Grupos & 6,330 & 1 & 6,330 & 5,862 & ,018 \\
\hline & Intra Grupos & 96,110 & 89 & 1,080 & & \\
\hline & Total & 102,440 & 90 & & & \\
\hline \multirow[t]{3}{*}{ V7 } & Entre Grupos &, 295 & 1 & .295 & .273 & .603 \\
\hline & Intra Grupos & 96,276 & 89 & 1,082 & & \\
\hline & Total & 96,571 & 90 & & & \\
\hline \multirow[t]{3}{*}{ V8 } & Entre Grupos & 1,101 & 1 & 1,101 & 1,482 & .227 \\
\hline & Intra Grupos & 66,086 & 89 &, 743 & & \\
\hline & Total & 67,187 & 90 & & & \\
\hline
\end{tabular}

Tabela 15 - Significância da diferença entre os grupos para a variável "cortesia"

Observando os valores da coluna Sig, vemos que apenas aqueles ligados aos vídeos celular $+(\mathrm{p}<0,01)$, celular $-(\mathrm{p}=0,006)$, água $+(\mathrm{p}=0,009)$ e água $-(\mathrm{p}=0,018)$ são significantes. Isso quer dizer que, de acordo com os resultados da ANOVA, apenas eles apresentam diferenças 
estatisticamente significantes entre os grupos BR e IT no que diz respeito aos níveis de cortesia. Se retomarmos a discussão feita até este ponto sobre a variável cortesia, acabamos de confirmar a hipótese que foi sendo construída ao longo análise dos dados brutos e das médias gerais e por grupo: aquela de que quatro dos oito vídeos apresentaram diferenças entre os grupos BR e IT. Apresentamos, na tabela a seguir, um resumo dos resultados relativos às percepções de brasileiros e italianos.

\begin{tabular}{|c|c|c|c|c|c|c|c|c|c|c|c|}
\hline \multicolumn{9}{|c|}{ Percepções análogas } & \multicolumn{6}{c|}{ Percepções distintas } \\
\hline Vídeo & Tipo & GI & GF & $\begin{array}{c}\text { Média } \\
\text { BR }\end{array}$ & $\begin{array}{c}\text { Média } \\
\text { IT }\end{array}$ & Vídeo & Tipo & GI & GF & $\begin{array}{c}\text { Médi } \\
\text { a BR }\end{array}$ & $\begin{array}{c}\text { Média } \\
\text { IT }\end{array}$ \\
\hline $\mathbf{1}$ & Caneta + & baixo & $6-10$ & 3,95 & 3,86 & $\mathbf{3}$ & Celular + & alto & $6-10$ & 3,50 & 2,76 \\
\hline $\mathbf{2}$ & Caneta - & baixo & $0-5$ & 3,28 & 3,61 & $\mathbf{4}$ & Celular - & alto & $0-5$ & 4,43 & 3,80 \\
\hline $\mathbf{7}$ & Temporal + & alto & $6-10$ & 2,65 & 2,76 & $\mathbf{5}$ & Água + & baixo & $6-10$ & 4,03 & 3,45 \\
\hline $\mathbf{8}$ & Temporal - & alto & $0-5$ & 4,30 & 4,08 & $\mathbf{6}$ & Água - & baixo & $0-5$ & 4,10 & 3,57 \\
\hline
\end{tabular}

Tabela 16 - Vídeos que causaram percepções análogas e distintas nos grupos BR e IT

Com o intuito de entender o que motivou as percepções que vimos até agora, poderíamos, como fizemos ao falar dos pedidos que tiveram a melhor e a pior avaliação por parte de BR e IT (com base nas médias totais), levar em consideração os elementos pragmalinguísticos (por exemplo, os modificadores) que foram utilizados para a realização dos pedidos e suas variáveis sociológicas (grau de imposição e familiaridade). No entanto, para que nossas considerações sobre os dados seja melhor embasada, realizamos outros testes estatísticos, baseados no nível de importância que os informantes atribuíram aos fatores submetidos a eles em nosso questionário. Isso nos permitiu dizer com maior segurança o que pode ter influenciado a percepção da cortesia de BR e IT. Os resultados desses testes serão apresentados na seção a seguir.

\subsection{Impacto das variáveis $Q$ sobre o nível de cortesia}

Após analisar os resultados ligados aos níveis de cortesia, verifiquemos agora de que maneira as 19 variáveis mencionadas no capítulo anterior influenciaram a percepção dos informantes brasileiros e italianos. Conforme o que dissemos sobre a forma de análise dos 
dados, essa interação será entendida por meio da análise dos resultados da regressão linear (impacto das variáveis independentes sobre uma dependente) da variável cortesia controlada pelos vídeos. Assim como no caso do teste ANOVA que calculou a diferença entre os grupos no que se refere à cortesia, também para os resultados que estamos para analisar o índice de confiança - representado por $\mathbf{p}$ - é de $95 \%$, de modo que os valores de p devem ser sempre menores que 0,05. Nas tabelas que analisaremos a seguir, o erro padrão (EP), como na análise anterior, é apresentado a título de informação sobre a variabilidade da amostra. Os valores a serem observados são aqueles de p e B (Beta coeficiente ${ }^{23}$ ): quando alguma variável Q se mostrar significante $(\mathrm{p}<0,05)$, quer dizer que a cada vez que ela recebeu um ponto na escala de avaliação de 0 a 5, o nível de cortesia geral ou de cada vídeo aumentou ou diminuiu na proporção de B.

Antes de verificar de que maneira as variáveis Q interagiram com os níveis de cortesia em cada um dos oito vídeos, vejamos na tabela a seguir de que maneira elas influenciaram os níveis de cortesia em geral.

${ }^{23}$ Valor dos coeficientes da regressão linear realizada com o SPSS. 


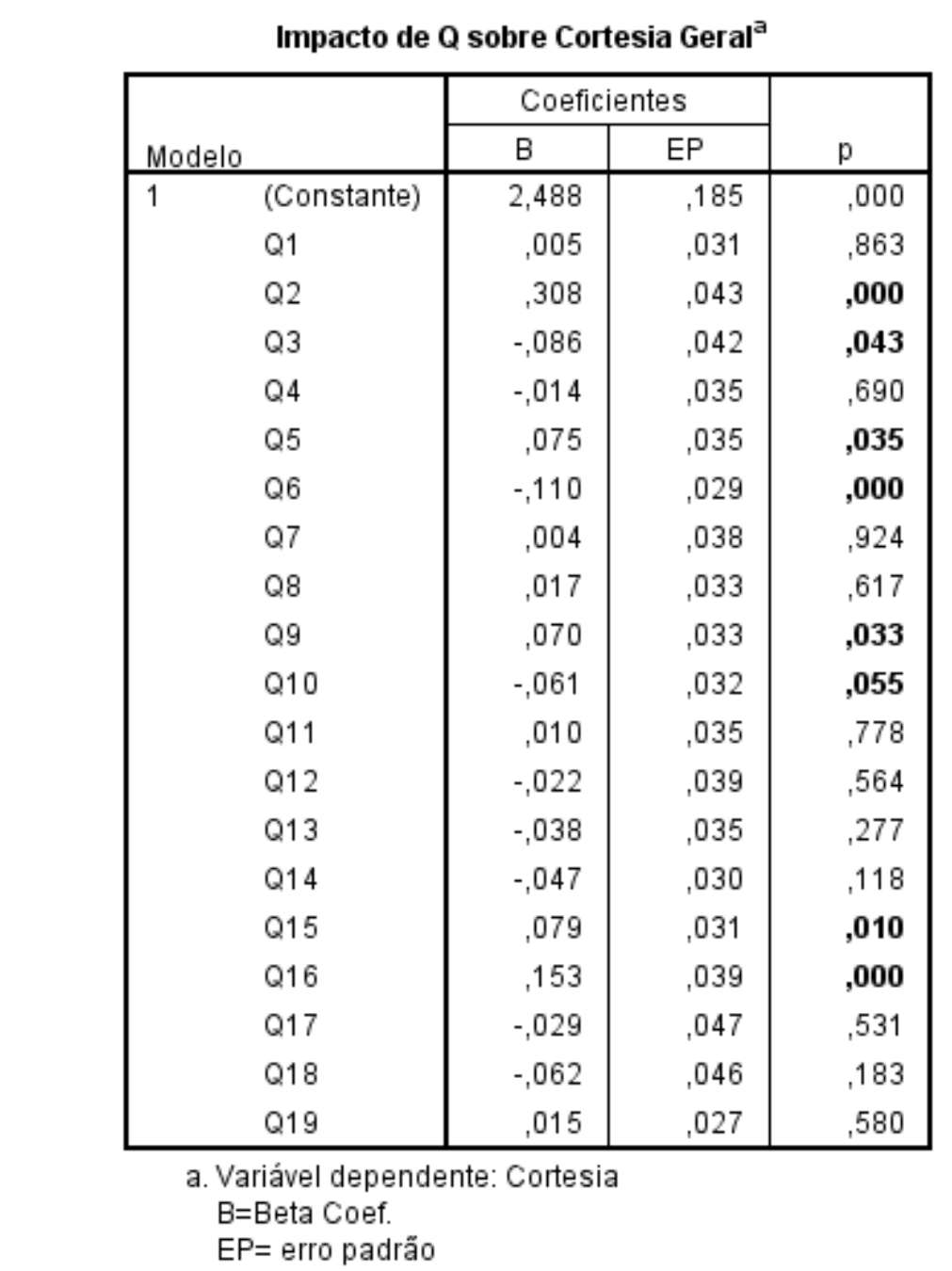

Tabela 17 - Resultados para o impacto das variáveis Q sobre a cortesia geral

Das 19 variáveis $Q$, oito apresentaram $\mathrm{p}<0,05$ e se mostraram significantes, tendo uma influência considerável sobre a cortesia. Comecemos pelas variáveis Q2 (agradecimentos) e Q16 (entoação) que, com p < 0,001, exerceram um impacto relevante sobre a percepção da cortesia em geral. Se houvesse apenas uma escala para indicar o nível de cortesia presente em todos os vídeos, isso significaria que, a cada ponto assinalado nas escalas de 0 a 5 referentes a Q2 e Q16, o nível de cortesia geral aumentaria (segundo os valores de B) em 0,308 pontos para Q2 e 0,153 para Q16. Uma vez que todos os pedidos são dotados de contorno entoacional, podemos dizer com segurança que Q16, a entoação, mostrou-se relevante para a percepção da cortesia. Já a variável Q2, agradecimentos, pode estar tanto presente quanto ausente na amostra de vídeos que utilizamos. De acordo com o levantamento apresentado na tabela 8, ela está presente em todos os vídeos. Nesse caso, o que os valores de p e B indicam é que a presença dos agradecimentos favorece uma percepção positiva da cortesia. 
Também a variável Q6, os reforçadores (como urgente, subito), presentes em cinco dos oito vídeos, apresentou $\mathrm{p}<0,001$, mas sua relação com o nível de cortesia é oposta à que acabamos de ver: a cada ponto assinalado na escala de avaliação de Q6, o nível geral de cortesia diminuiu, sendo $B=-0,110$. Outras variáveis a influenciar negativamente a percepção da cortesia foram Q3, fórmulas de cortesia, e Q10, condicional (futuro do pretérito). Essas duas variáveis não são frequentes nos vídeos analisados: a primeira aparece duas e a segunda três vezes. Portanto, podemos dizer que a ausência de fórmulas de cortesia $(B=-0,086)$ e do condicional $(\mathrm{B}=-0,061)$, em geral, implicam em uma percepção negativa da cortesia.

As variáveis Q5 - atenuadores (tais como un attimo, um momento; piccola, pequena), e Q9 - imperfeito (como volevo, queria), ainda que pouco frequentes nos vídeos apresentados aos informantes (duas ocorrências de atenuadores e uma de imperfeito), também se mostraram impactantes quanto à percepção da cortesia: ambas favoreceram uma percepção mais positiva, tendo coeficientes $\mathrm{B}=0,075$ e $\mathrm{B}=0,070$, respectivamente. $\mathrm{O}$ grau de imposição (Q15), por sua vez, também teve impacto considerável: a cada ponto em sua escala de avaliação, a cortesia geral aumentou 0,79 pontos.

Na tabela abaixo, há um elenco das variáveis significantes para o nível de cortesia em geral, bem como uma indicação sobre a ocorrência delas nos pedidos. Há também dados referentes ao coeficiente B, que indica o quanto o nível de cortesia geral aumentou (se o valor for positivo) ou diminuiu (se o valor for negativo) a cada vez que um nível era selecionado na escala de avaliação da variável sob análise. Vale dizer que os dados sobre a ocorrência dos modificadores nos vídeos foram inseridos apenas a título de informação, já que os cálculos que geraram os resultados do coeficiente $\mathrm{B}$ consideraram os números totais. 


\begin{tabular}{|c|c|c|c|}
\hline Sigla & Variável & $\begin{array}{c}\text { Beta coeficiente } \\
\text { (B) }\end{array}$ & $\begin{array}{c}\text { Ocorrências nos } \\
\text { vídeos }\end{array}$ \\
\hline Q2 & agradecimentos & 0,308 & todos \\
\hline Q3 & fórmulas de cortesia & $\mathbf{- 0 , 0 8 6}$ & 1 e 2 \\
\hline Q5 & atenuadores & 0,075 & 3 e 8 \\
\hline Q6 & reforçadores & $\mathbf{- 0 , 1 1 0}$ & $3,4,5,7$ e 8 \\
\hline Q9 & imperfeito & 0,070 & 1 \\
\hline Q10 & condicional & $\mathbf{- 0 , 0 6 1}$ & 4 e 8 \\
\hline Q15 & grau de imposição & 0,079 & todos \\
\hline Q16 & entoação & 0,153 & todos \\
\hline
\end{tabular}

Tabela 18 - Variáveis com correlação significante com os níveis de cortesia em geral

\section{- Resultados vídeo 1 (caneta +)}

Passemos agora à análise da interação entre as variáveis Q e os níveis de cortesia atribuídos a cada um dos vídeos. O primeiro dos pedidos apresentados aos informantes, caneta + (grau de imposição baixo, grau de familiaridade médio-alto), que, como vimos, apresentou resultados bastante semelhantes entre os grupos no que toca aos níveis de cortesia (média geral de 3,90), foi realizado com diversos modificadores: agradecimento, fórmula de cortesia, duvidador, fórmula de apelo, imperfeito, verbo modal e justificativa. Tal comportamento linguístico não corresponderia aos resultados de estudos que avaliam qual a frequência de modificadores de acordo com variáveis como o grau de imposição, a distância social e o poder relativo, como aquele de Spadotto e Santoro (2016), que verificou uma alta frequência de modificadores nos casos em que o grau de imposição é alto e a familiaridade é baixa. Apesar dessa quantidade de modificadores, o teste ANOVA indicou valor de $\mathrm{p}<0,05$ para apenas duas variáveis, que não são modificadores: Q16, a entoação, e Q19, a forma de tratamento. 


\begin{tabular}{|c|c|c|c|c|}
\hline \multirow{2}{*}{\multicolumn{2}{|c|}{ Modelo }} & \multicolumn{2}{|c|}{ Coeficientes } & \multirow[b]{2}{*}{$\mathrm{p}$} \\
\hline & & $\mathrm{B}$ & $\mathrm{EP}$ & \\
\hline \multirow[t]{20}{*}{1} & (Constante) & 3,375 &, 530 &, 000 \\
\hline & Q1 &,- 103 &, 063 & , 108 \\
\hline & Q2 &, 110 & 110 &, 318 \\
\hline & Q3 &,- 004 & 117 & 973 \\
\hline & Q4 & ,106 & ,081 & ,193 \\
\hline & Q5 &, 099 & ,078 &, 208 \\
\hline & Q6 &,- 008 &, 087 &, 925 \\
\hline & Q7 &, 047 & 103 &, 649 \\
\hline & Q8 &,- 032 &, 068 &, 639 \\
\hline & Q9 &, 084 &, 079 & 293 \\
\hline & Q10 &,- 107 &, 077 & , 168 \\
\hline & Q11 &,- 059 &, 072 &, 413 \\
\hline & Q12 &,- 060 &, 084 &, 482 \\
\hline & Q13 &, 039 & ,073 & 601 \\
\hline & Q14 &, 010 &, 071 & 892 \\
\hline & Q15 &, 005 &, 071 & 939 \\
\hline & Q16 &, 225 & 105 & ,036 \\
\hline & Q17 &,- 014 & ,113 &, 898 \\
\hline & Q18 &,- 153 & 102 & ,138 \\
\hline & Q19 &,- 130 & ,059 & ,031 \\
\hline \multicolumn{5}{|c|}{ a. V. dependente: Cortesia } \\
\hline \multicolumn{5}{|c|}{$\begin{array}{l}\text { b. Video1 } \\
\text { B=Beta coef. } \\
\text { EP=erro padrão }\end{array}$} \\
\hline
\end{tabular}

Tabela 19 - Resultados para o impacto das variáveis Q sobre a cortesia - vídeo 1

No caso da entoação, a cada vez que um informante selecionava um ponto na escala de 0 a 5, o nível de cortesia atribuído ao pedido aumentava em 0,225 pontos. Por outro lado, o impacto da forma de tratamento, que no vídeo em questão era $t u$, foi negativo, sendo B = 0,130. A familiaridade entre as pessoas que interagiam nesse vídeo era médio-alta, o que justifica, de acordo com os valores socioculturais vigentes entre os italianos, o uso do pronome $t u$. Uma explicação possível para esse efeito negativo poderia ser o fato de as falantes do vídeo terem uma diferença de idade relativamente considerável, o que seria um motivo para o uso de um pronome que denota mais formalidade ou respeito, o lei, considerando as regras normalmente observadas, em italiano, para a escolha do pronome a ser utilizado em uma interação. Outra possibilidade seria que, ao longo do diálogo, o grau de familiaridade entre as falantes não tenha ficado claro para os informantes. No entanto, essas são apenas hipóteses, pois não dispomos de dados que as possam confirmar. De qualquer maneira, de modo geral, 
considerando também a influência das outras variáveis que não alcançaram o índice de confiança de $95 \%$, foi considerado por ambos os grupos que esse pedido possui um grau médio de cortesia (média total de 3,90).

\section{- Resultados vídeo 2 (caneta - )}

\begin{tabular}{|c|c|c|c|c|}
\hline \multirow{2}{*}{\multicolumn{2}{|c|}{ Modelo }} & \multicolumn{2}{|c|}{ Coeficientes } & \multirow[b]{2}{*}{$\mathrm{p}$} \\
\hline & & B & EP & \\
\hline 1 & (Constante) & 2,924 & 458 & 000 \\
\hline & Q1 &,- 040 & ,139 &, 776 \\
\hline & Q2 &, 371 &, 149 & ,015 \\
\hline & Q3 &,- 161 & 147 &, 278 \\
\hline & Q4 &, 080 &, 084 & ,341 \\
\hline & Q5 &,- 075 & ,096 & ,436 \\
\hline & Q6 &,- 120 &, 140 & ,394 \\
\hline & Q7 &,- 086 & 119 &, 470 \\
\hline & Q8 & 151 &, 086 &, 083 \\
\hline & Q9 &, 081 & ,089 &, 363 \\
\hline & Q10 &,- 015 &, 089 & ,865 \\
\hline & Q11 &,- 102 & 103 &, 323 \\
\hline & Q12 & ,156 & ,106 & , 148 \\
\hline & Q13 &,- 015 & , 105 & ,884 \\
\hline & Q14 &,- 049 &, 069 & ,478 \\
\hline & Q15 &, 006 & 071 &, 929 \\
\hline & Q16 &, 044 & ,104 &, 675 \\
\hline & Q17 &,- 221 & ,125 &, 082 \\
\hline & Q18 &,- 065 & , 125 &, 602 \\
\hline & Q19 & , 139 & ,078 &, 079 \\
\hline
\end{tabular}

a. V. dependente: Cortesia

b. Video2

$\mathrm{B}=$ Beta coef.

$\mathrm{EP}=$ erro padrão

Tabela 20 - Resultados para o impacto das variáveis Q sobre a cortesia - vídeo 2

A variável Q2, agradecimentos, foi a única que se mostrou estatisticamente significante, para o pedido caneta - (grau de imposição baixo, grau de familiaridade médiobaixo), que teve média total referente ao nível de cortesia igual a 3,46. Com $\mathrm{B}=0,371$, o impacto da presença dessa variável foi positivo, aumentando a percepção da cortesia. Se observarmos a transcrição do vídeo de que estamos tratando, vemos que o pedido foi realizado de maneira bastante direta (foram utilizadas apenas fórmulas de cortesia e de apelo e o 
agradecimento) e que o ouvinte, não dispondo do objeto solicitado, tentou oferecer algumas alternativas.

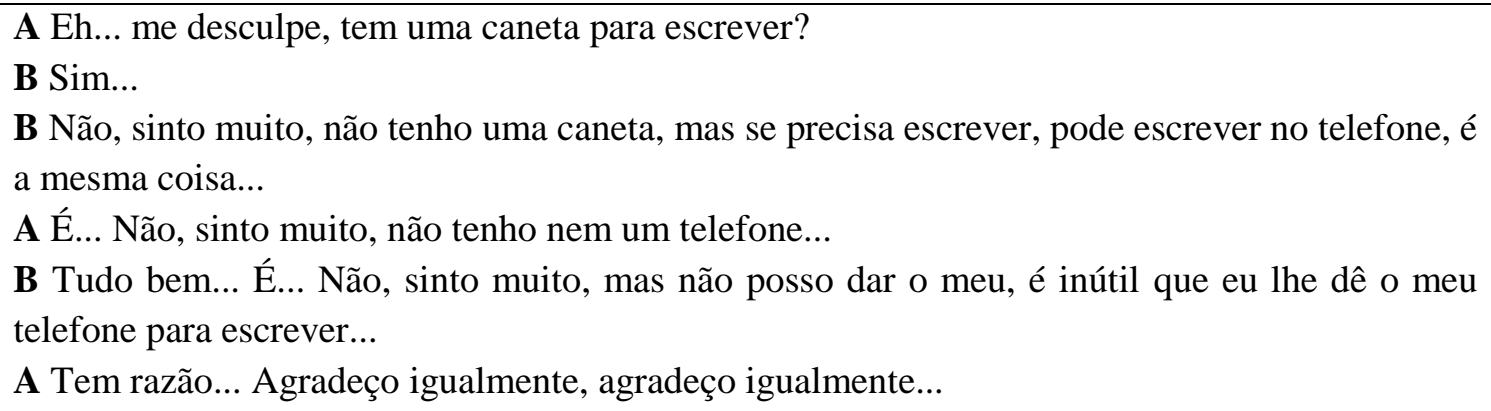

Tabela 21 - Transcrição (em português) do vídeo 2

Como vimos, o agradecimento, nesse caso, foi repetido duas vezes por quem realizou o pedido, mesmo não tendo obtido o efeito esperado do ato de fala que proferiu. Isso pode ser um indício de que, para os informantes brasileiros e italianos (uma vez que para o vídeo 2 as percepções de ambos os grupos são análogas), é importante agradecer independentemente do resultado do pedido. Se pensarmos nos termos de Sbisà (2009 [1989]), ainda que o ato de fala não tenha surtido o efeito esperado, ao menos houve um efeito de recepção e isso já seria suficiente para influenciar a percepção da cortesia.

\section{- Resultados vídeo 3 (celular + )}

O teste ANOVA não apresentou resultados significantes para nenhuma das 19 variáveis Q em relação à percepção cortesia presente no pedido do vídeo celular + , o que não significa que nenhuma delas influenciou a percepção dos falantes, mas que nenhuma alcançou o índice de confiança que havíamos estabelecido. 
Impacto de Q sobre cortesia V3 ${ }^{a, b}$

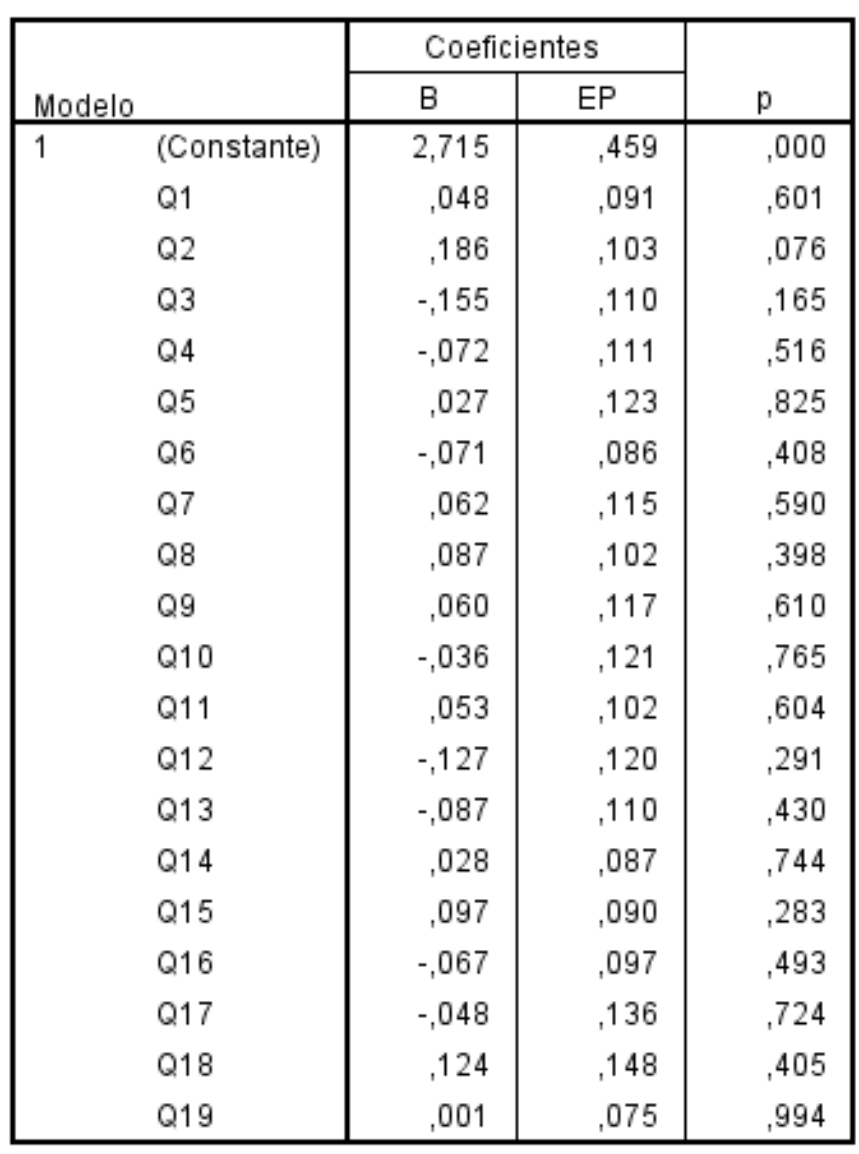

a. Var. dependente: Cortesia

b. Video3

B=Beta coef

$\mathrm{EP}=$ erro padrão

Tabela 22 - Resultados para o impacto das variáveis Q sobre a cortesia - vídeo 3

Isso pode se dever ao fato de que, particularmente no caso desse vídeo, as respostas foram de tal modo dispersas entre as 19 variáveis que não foi possível estabelecer uma correlação mais forte entre elas e os níveis de cortesia atribuídos ao vídeo. Ainda assim, vemos que Q2 (agradecimento) foi a variável que mais se aproximou do índice estabelecido, com impacto positivo, seguindo a tendência que vimos quando da análise do impacto das variáveis Q sobre a cortesia em geral.

\section{- Resultados vídeo 4 (celular - )}

Com alto grau de imposição (celular) em que os falantes a interagir tinham grau de familiaridade médio-baixo, o pedido celular - foi realizado com agradecimento, duvidador, 
reforçador, condicional, verbo modal, interrogativa negativa e justificativa, ou seja, sete modificadores. A média geral de nível de cortesia igual a 4,08, mas este é um dos casos em que houve percepções diversas entre os grupos, sendo que foram os brasileiros a ter a melhor avaliação $(4,43$, enquanto a média dos italianos foi de 3,80$)$.

\begin{tabular}{|c|c|c|c|c|}
\hline \multirow{2}{*}{\multicolumn{2}{|c|}{ Modelo }} & \multicolumn{2}{|c|}{ Coeficientes } & \multirow[b]{2}{*}{$p$} \\
\hline & & $\mathrm{B}$ & $\mathrm{EP}$ & \\
\hline \multirow[t]{20}{*}{1} & (Constante) & 2,694 & ,488 &, 000 \\
\hline & Q1 &,- 109 & ,104 & 298 \\
\hline & Q2 &, 321 &, 156 & ,043 \\
\hline & Q3 &, 027 &, 153 &, 859 \\
\hline & Q4 &,- 046 &, 124 &, 710 \\
\hline & Q5 &, 282 &, 096 &, 004 \\
\hline & Q6 &,- 256 & ,096 & ,009 \\
\hline & Q7 &, 253 & ,105 & ,018 \\
\hline & Q8 &,- 147 & 113 & ,197 \\
\hline & Q9 &, 110 &, 084 & ,195 \\
\hline & Q10 &,- 179 & ,096 &, 067 \\
\hline & Q11 &, 133 & , 103 & 199 \\
\hline & Q12 &,- 034 & , 109 &, 756 \\
\hline & Q13 &,- 084 & 113 & ,458 \\
\hline & Q14 &,- 223 &, 075 &, 004 \\
\hline & Q15 &, 030 & ,087 &, 730 \\
\hline & Q16 & , 141 & ,117 &, 234 \\
\hline & Q17 &, 151 &, 147 & ,308 \\
\hline & Q18 &,- 244 & 187 & ,196 \\
\hline & Q19 &, 252 & ,072 & ,001 \\
\hline \multicolumn{5}{|c|}{ a. Var. dependente: Cortesia } \\
\hline \multicolumn{5}{|c|}{$\begin{array}{l}\text { b. Video } 4 \\
\text { B=Beta coef. } \\
\text { EP=erro padrão }\end{array}$} \\
\hline
\end{tabular}

Tabela 23 - Resultados para o impacto das variáveis Q sobre a cortesia - vídeo 4

A ANOVA indicou $p$ significante para seis variáveis, mas nem todas correspondem aos elementos efetivamente utilizados para realizar o pedido. Seguindo a tendência vista nos dados relativos à interação entre $\mathrm{Q}$ e a cortesia geral, o uso dos agradecimentos $(\mathrm{Q} 2), \operatorname{com} \mathrm{B}=$ 0,321, teve impacto positivo sobre a percepção dos informantes. Os atenuadores (Q5) não foram utilizados no pedido em questão, no entanto, os resultados mostram que, de alguma maneira, o fato de eles não terem sido usados aumentou a percepção da cortesia, sendo $B=0,282$. Utilizar 
um reforçador (Q6) teve impacto negativo sobre a cortesia atribuída ao pedido em questão, com $\mathrm{B}=-0,256$. Uma vez que o impacto dessa variável foi negativo e, como vimos, os italianos atribuíram uma média de cortesia menor em relação aos brasileiros, podemos supor que, para os italianos, o uso de um reforçador afeta negativamente a percepção da cortesia.

A ausência de preenchimentos (Q7), que, inclusive, não foram utilizados em nenhum dos vídeos da amostra, aumentou a percepção da cortesia em 0,253 pontos. $O$ grau de familiaridade (Q14), que nesse caso é médio-baixo e que até o momento não havia sido significativo nem em geral nem para algum vídeo em específico, não favoreceu uma percepção positiva da cortesia, apresentando um valor negativo para o coeficiente B (-0,223). A última variável significante para o vídeo 4 foi Q19 $(\mathrm{p}=0,001)$, a forma de tratamento, nesse caso o uso de lei. A cada ponto selecionado pelos informantes na escala de avaliação referente a essa variável, a percepção da cortesia aumentava em 0,252 pontos.

A partir desses resultados, façamos algumas reflexões. O fato de a utilização de um agradecimento ter favorecido uma percepção positiva da cortesia presente no pedido não causa estranheza, visto que nos dados gerais essa variável já havia apresentado o mesmo comportamento. Tampouco uma percepção positiva do uso do pronome de tratamento (Q19) adequado a uma situação comunicativa entre duas pessoas que se encontram pela primeira vez na rua parece incomum, considerando os aspectos sociopragmáticos do italiano, conhecidos também pelos aprendizes brasileiros (o que pode ser afirmado com certa segurança porque as diferentes formas de tratamento existentes em italiano e as regras que regulam seu uso são abordadas com muita frequência, em geral, durante o ensino dessa língua). O impacto positivo da ausência de preenchimentos (Q7), por sua vez, poderia ser justificado por poder dar a entender que quem faz o pedido não parece hesitante, mas decidido sobre a necessidade de obter ajuda, se pensarmos na definição que temos do modificador, baseada em Nuzzo (2012). Para entender o fato de o não uso de atenuadores (Q5) ter tido um impacto positivo, podemos dizer que, de certo modo, sua ausência teria sido compensada pela presença de outros elementos, como o duvidador e o condicional. O dado de interpretação mais difícil, porém, parece ser que o grau de familiaridade (Q14), que nesse pedido é médio-baixo, tenha tido impacto negativo na percepção da cortesia. Talvez a observação do conjunto de dados esconda alguma possível interpretação que, em uma análise futura, poderia considerar cada informante individualmente. 
- Resultados vídeo 5 (água + ) e 6 (água -)

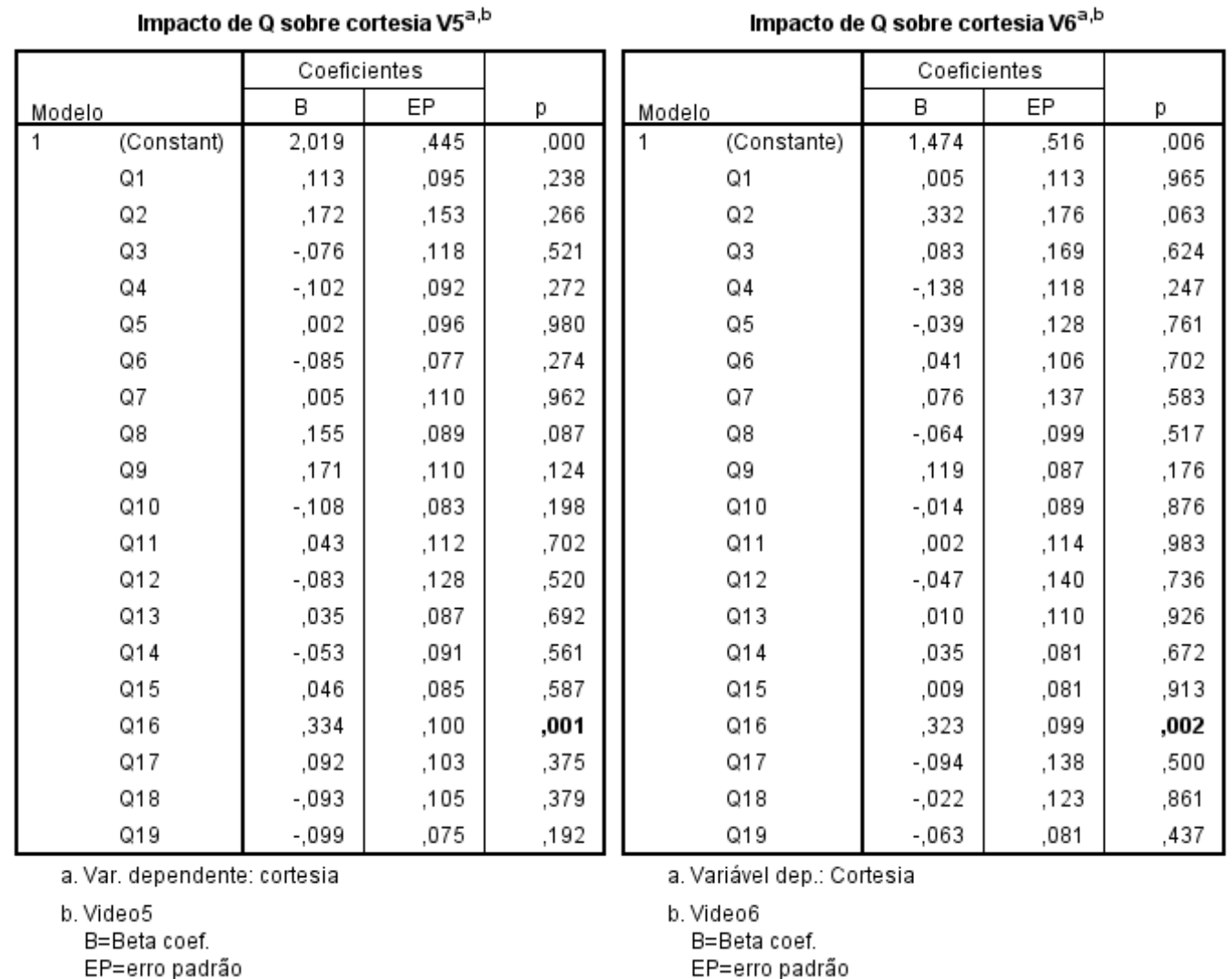

Tabela 24 - Resultados para o impacto das variáveis Q sobre a cortesia - vídeos 5 e 6

O pedido presente no vídeo 5, cujos participantes tinham grau de familiaridade médio-alto, era de um copo d'água e foi realizado com saudação, agradecimento, reforçador, fórmula de apelo e justificativa (em negrito na transcrição a seguir). 


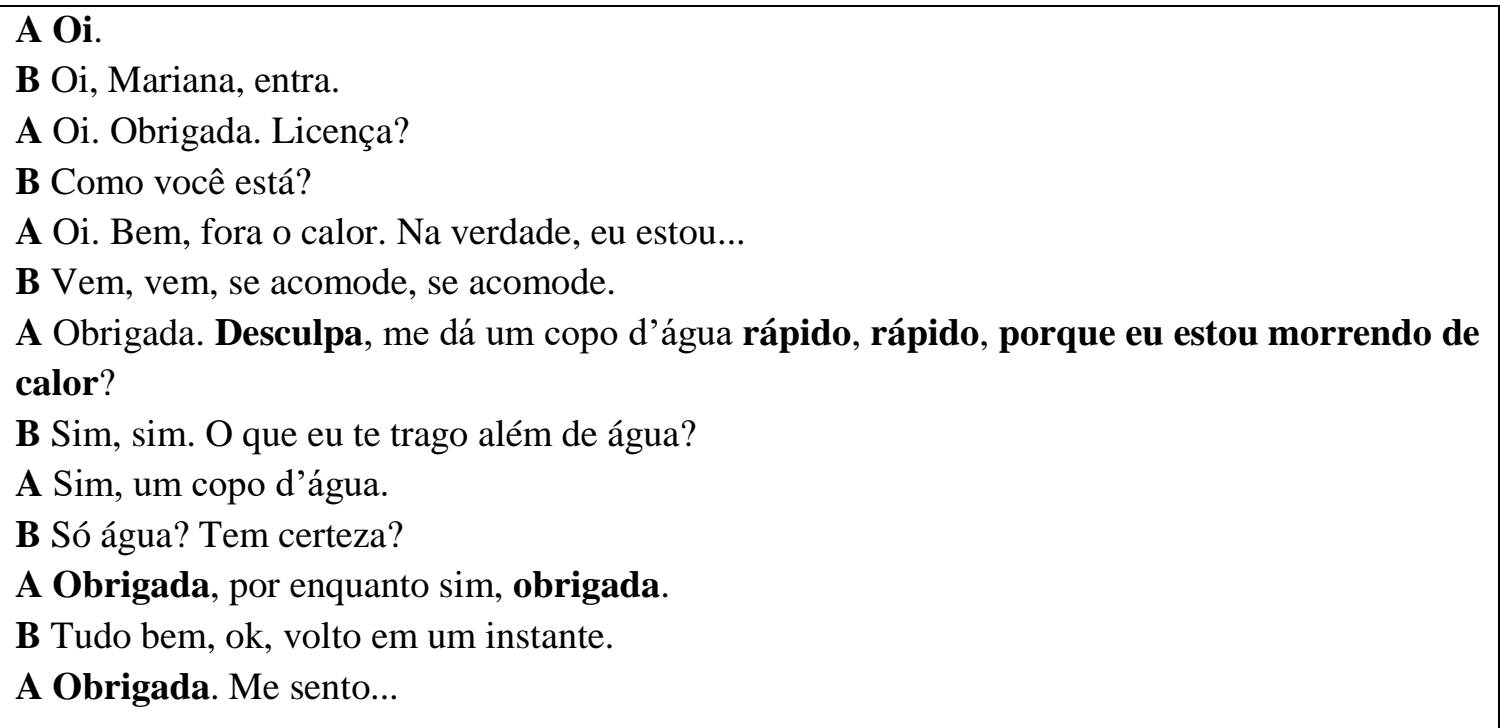

Tabela 25 - Transcrição (em português) do vídeo 5

A média total do nível de cortesia a ele atribuído foi de 3,70 e, como ocorreu com os vídeos que suscitaram percepções diferentes, os brasileiros apresentaram uma avaliação mais positiva que os italianos. Apesar de termos cinco modificadores no pedido em questão, apenas a variável Q16, a entoação, resultou significante após a ANOVA.

Algo parecido ocorreu com o pedido do vídeo número 6, também de um copo d'água, mas com grau de familiaridade médio-baixo e nível de cortesia com média total de 3,80. O pedido foi realizado com saudação, agradecimento, imperfeito, verbo modal e um preparador, mas a única variável significante, novamente, foi a entoação.

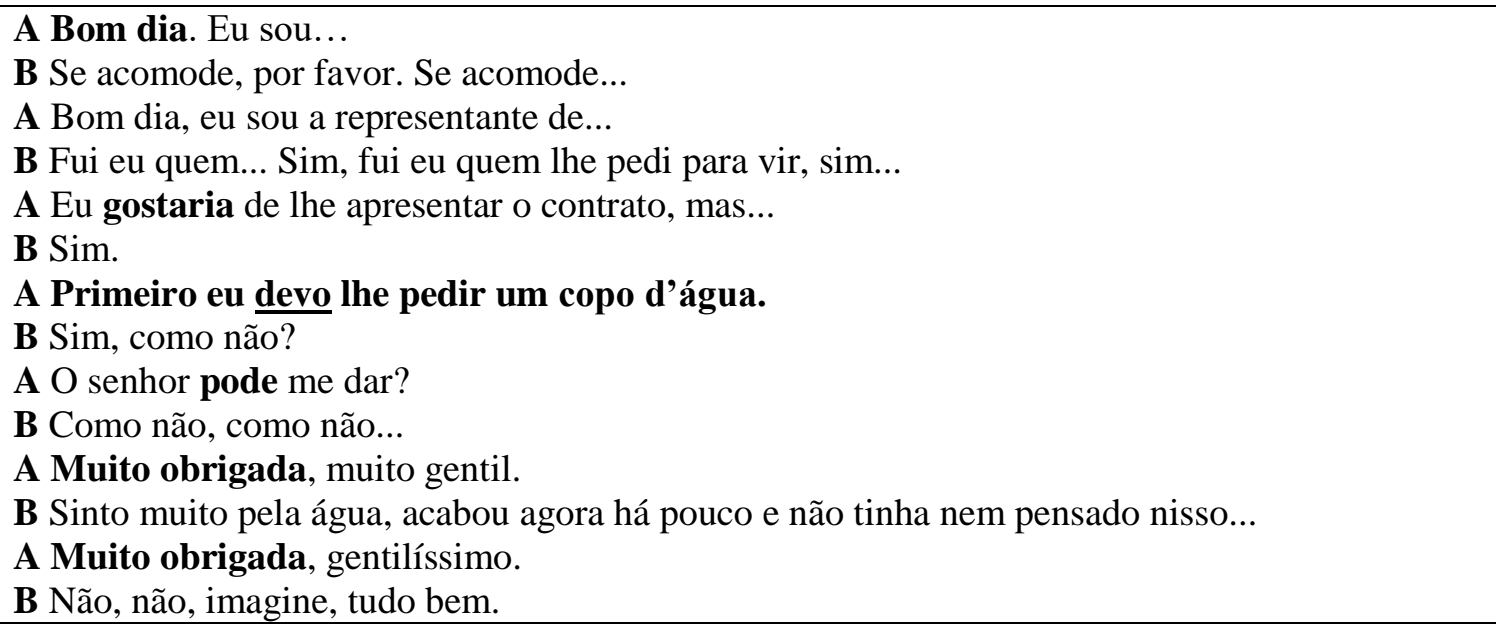


Em ambos os casos, o impacto dessa variável foi positivo e, inclusive, o nível de cortesia aumentou em função dela em proporções semelhantes, sendo $\mathrm{B}=0,334$ para o vídeo 5 ( $\mathrm{p}=0,001)$ e $\mathrm{B}=0,323$ para o vídeo $6(\mathrm{p}=0,002)$.

\section{- Resultados vídeo 7 (temporal + )}

O pedido contido no vídeo 7, com alto grau de imposição e grau de familiaridade entre os falantes médio-alto, como vemos na transcrição a seguir, foi realizado com agradecimento, reforçador e justificativa.

A Nossa, Daniela, está caindo um dilúvio, olha como estou toda molhada!

B O que aconteceu? Nossa... Escuta, vou te dar uma toalha, você se seca e depois eu te dou um secador de cabelo.

A Sim, não, tudo bem... Mas não me basta uma toalha, eu teria que tirar, secar as roupas...

B Eu te dou a...

A Me dá um robe, uma calça, uma camiseta...

B Eu te dou, te dou um vestido meu.

A Sim, alguma coisa... Não, olha, estou ensopada!

B Eu te trago um vestido... Não se preocupe...

A Antes que eu pegue uma gripe

B Vai tirar a roupa enquanto isso

A Sim, sim, obrigada, obrigada.

B Eu te trago o vestido.

Tabela 27 - Transcrição (em português) do vídeo 7

O teste ANOVA mostrou que três variáveis foram impactantes para a percepção da cortesia presente no pedido nele contido. No entanto, como veremos, essas três variáveis não coincidem com os três modificadores utilizados pela falante. 
Impacto de Q sobre cortesia - V7 $7^{\mathrm{a}, \mathrm{b}}$

\begin{tabular}{|c|c|c|c|c|}
\hline \multirow{2}{*}{ Mode } & & \multicolumn{2}{|c|}{ Coeficientes } & \multirow[b]{2}{*}{$p$} \\
\hline & & B & EP & \\
\hline \multirow[t]{20}{*}{1} & (Constante) & 3,638 &, 576 &, 000 \\
\hline & Q1 & - 108 & 104 & 301 \\
\hline & Q2 & ,076 & 108 & , 487 \\
\hline & Q3 & -086 & ,134 &, 524 \\
\hline & Q4 &,- 069 & , 126 &, 586 \\
\hline & Q5 & ,018 & 120 & 881 \\
\hline & Q6 & 104 & ,090 & , 250 \\
\hline & Q7 &, 092 & ,111 & .412 \\
\hline & Q8 & -197 & ,112 & ,084 \\
\hline & Q9 &,- 043 & , 107 & ,687 \\
\hline & Q10 & -050 & ,093 & , 593 \\
\hline & Q11 & 196 &, 086 & ,026 \\
\hline & Q12 &,- 099 & ,125 & ,432 \\
\hline & Q13 &,- 034 &, 109 &, 758 \\
\hline & Q14 & ,019 & ,097 & ,847 \\
\hline & Q15 & ,204 &, 089 & ,025 \\
\hline & Q16 &,- 239 & 119 & ,049 \\
\hline & Q17 &, 041 &, 119 &, 734 \\
\hline & Q18 &,- 030 &, 120 & 803 \\
\hline & Q19 &,- 083 & ,071 & 247 \\
\hline
\end{tabular}

a. Variável dep.: Cortesia

b. Video7

B=Beta coef.

$\mathrm{EP}=$ erro padråo

Tabela 28 - Resultados para o impacto das variáveis Q sobre a cortesia - vídeo 7

A primeira delas é a Q11, verbos modais. No pedido em questão não há verbos desse tipo, no entanto, o impacto dessa variável sobre a percepção da cortesia foi positivo (B = 0,196, p=0,026). O grau de imposição ( $\mathrm{Q} 15, \mathrm{p}=0,025)$ também exerceu impacto positivo, melhorando a percepção da cortesia em 0,204 pontos a cada nível selecionado na escala de 0 a 5 referente à variável em questão. Para propor uma interpretação a esse dado, podemos observar, novamente, a transcrição do pedido. Ao analisar a interação, vemos que a falante constrói seu discurso de modo a transparecer que a situação é grave (“está caindo um dilúvio...") e que se não tiver a ajuda necessária, corre o risco de adoecer (“antes que eu pegue uma gripe"). Esse sentido de urgência e de risco à integridade física, "representado" pelo grau de imposição do pedido, pode ter levado os informantes a avaliar como secundária a necessidade de utilizar um verbo modal. 
A terceira variável significante para o pedido que estamos analisando foi, como ocorreu em outros vídeos, a entoação (Q16, p=0,049). Porém, esse foi o único caso em que seu impacto foi negativo: o nível de cortesia atribuído ao pedido de que estamos tratando diminuía 0,239 pontos (valor de B negativo) sempre que os informantes selecionavam um ponto a mais em sua escala de avaliação. Como já dissemos anteriormente, o pedido do vídeo 7 foi aquele que teve menor média de nível de cortesia: 2,71. Uma vez que a entoação, de um modo geral, exerceu um impacto positivo na percepção da cortesia da nossa amostra de pedidos, o fato de o único caso em que essa variável teve impacto negativo ser aquele do pedido com percepção mais negativa reforça a relevância dessa variável para a percepção da cortesia. Talvez uma análise da curva entoacional e um teste de percepção ligado a esse aspecto fosse útil para entender por qual motivo ele influenciou negativamente a percepção da cortesia tanto de falantes brasileiros quanto de italianos.

Como já vimos anteriormente, o pedido temporal + foi aquele com que recebeu avaliação mais negativa por ambos os grupos. Isso nos leva a crer que, apesar de toda a lógica do enunciado, com seus elementos contextuais de fato (nesse caso, as circunstâncias físicas) e de direito (relacionados às características da relação social entre as falantes), conforme diz Sbisà, 2009 [1989]), que influenciaram a opção da falante de não utilizar tantos modificadores para atenuar seu pedido, os informantes parecem ter considerado que essa não foi a melhor maneira de realizar o ato de fala em questão.

\section{- Resultados vídeo 8 (temporal - )}

O último pedido da amostra, de alto grau de imposição e grau de familiaridade médio-baixo, foi realizado com saudação, agradecimento, duvidador, atenuador, reforçador, condicional, verbo modal, fórmula dubitativa e preparador. Trata-se do vídeo que teve a avaliação do nível de cortesia mais positiva (média total de 4,18) e a maior quantidade de modificadores, o que parece indicar uma preocupação da falante em minimizar a ameaça à face negativa de sua interlocutora - com quem não tinha uma grande familiaridade - diante de um pedido razoavelmente invasivo. No entanto, apenas a variável Q12 foi significante $(p=0,020)$ : fórmula dubitativa, que foi utilizada duas vezes no pedido ("não sei como lhe dizer", "posso tomar um banho rápido, não sei, alguma coisa..."). 
De fato, este foi o único caso em que se utilizou esse modificador morfossintático e seu impacto foi positivo, sendo que a cada ponto selecionado em sua escala, o nível de cortesia atribuído a esse pedido aumentava em 0,247 pontos.

\begin{tabular}{|c|c|c|c|c|}
\hline \multirow{2}{*}{\multicolumn{2}{|c|}{ Modelo }} & \multicolumn{2}{|c|}{ Coeficientes } & \multirow[b]{2}{*}{$p$} \\
\hline & & $\mathrm{B}$ & $\mathrm{EP}$ & \\
\hline \multirow[t]{20}{*}{1} & (Constante) & 3,327 &, 555 &, 000 \\
\hline & Q1 &,- 110 & ,128 & ,390 \\
\hline & Q2 & ,195 & ,133 &, 145 \\
\hline & Q3 & ,082 &, 097 &, 402 \\
\hline & Q4 & ,023 & ,098 & 814 \\
\hline & Q5 &, 125 & 101 &, 222 \\
\hline & Q6 &,- 118 &, 079 &, 140 \\
\hline & Q7 &,- 068 &, 097 &, 487 \\
\hline & Q8 &, 076 &, 090 & 405 \\
\hline & Q9 &,- 042 & ,087 &, 629 \\
\hline & Q10 &,- 075 & 079 & ,346 \\
\hline & Q11 & 071 & ,112 &, 529 \\
\hline & Q12 &, 247 & , 104 & ,020 \\
\hline & Q13 &,- 138 &, 096 & , 155 \\
\hline & Q14 &,- 043 & 094 &, 643 \\
\hline & Q15 &, 004 &, 095 & ,968 \\
\hline & Q16 & 091 & ,113 & 426 \\
\hline & Q17 &,- 144 & ,194 & ,461 \\
\hline & Q18 &,- 012 & , 176 & 944 \\
\hline & Q19 &,- 001 & 074 & ,985 \\
\hline \multicolumn{5}{|c|}{ a. Var. dependente: Cortesia } \\
\hline \multicolumn{5}{|c|}{$\begin{array}{l}\text { b. Video } 8 \\
\text { Beta=Beta coef. } \\
\text { EP=erro padrão }\end{array}$} \\
\hline
\end{tabular}

Tabela 29 - Resultados para o impacto das variáveis Q sobre a cortesia - vídeo 8

Na tabela a seguir, apresentamos, para cada vídeo, as variáveis Q que que se mostraram significantes para a correlação com a percepção da cortesia manifestada pelos informantes brasileiros e italianos. Indicamos também se essas variáveis ocorrem nos pedidos em questão e os dados relativos ao Beta coeficiente, que revelam se o impacto dessas variáveis foi negativo ou positivo e em que proporção esse impacto ocorreu. 


\begin{tabular}{|c|c|c|c|c|}
\hline Vídeo & Sigla & Variável & $\begin{array}{c}\text { Ocorrências nos } \\
\text { vídeos }\end{array}$ & Beta coeficiente (B) \\
\hline \multirow{2}{*}{1} & Q16 & entoação & - & 0,225 \\
\hline 2 & Q19 & forma de tratamento & $t u$ & $\mathbf{- 0 , 1 3 0}$ \\
\hline 3 & - & agradecimentos & sim & 0,371 \\
\hline & Q2 & agradecimentos & - & - \\
& Q5 & atenuadores & não & 0,321 \\
& Q6 & reforçadores & sim & 0,282 \\
4 & Q7 & preenchimentos & não & $\mathbf{- 0 , 2 5 6}$ \\
& Q14 & grau de familiaridade & médio-baixo & 0,253 \\
& Q19 & forma de tratamento & lei & 0,223 \\
& Q16 & entoação & - & 0,252 \\
\hline 5 & Q16 & entoação & - & 0,323 \\
\hline 6 & Q11 & verbos modais & não & 0,196 \\
\hline \multirow{2}{*}{7} & Q15 & grau de imposição & alto & 0,204 \\
& Q16 & entoação & - & $\mathbf{- 0 , 2 3 9}$ \\
\hline 8 & Q12 & fórmulas dubitativas & sim & 0,247 \\
\hline
\end{tabular}

Tabela 30 - Variáveis com correlação significativa com os níveis de cortesia (por vídeo) 


\section{Conclusões}

Nosso intuito com este trabalho foi, a partir de uma amostra de oito pedidos, gravados em áudio e vídeo, verificar de que maneira brasileiros e italianos percebem a cortesia presente nesse ato de fala e o que poderia motivar essa percepção. Uma vez apresentados os resultados relativos tanto à percepção da cortesia quanto à influência que as variáveis que analisamos poderiam exercer sobre ela, responderemos às perguntas de pesquisa estabelecidas inicialmente, acrescentando também outras considerações sobre os resultados a que chegamos.

Respondemos, de imediato, à primeira pergunta de pesquisa que havíamos definido, que diz respeito a quais analogias e diferenças podem ser identificadas entre brasileiros e italianos quanto ao nível de cortesia atribuído aos pedidos. Vimos na introdução a esta pesquisa que, para a maioria dos trabalhos realizados no sentido de comparar a percepção que falantes nativos e não nativos têm da cortesia presente em pedidos em uma determinada língua, as percepções se mostram análogas (Walters, 1979; Carrel e Konneker, 1981; Matsuura, 1998). De acordo com a análise de nossos dados, verificamos que os resultados, de certo modo, dividiram a amostra de pedidos em duas partes iguais. De um lado, causaram percepções semelhantes um pedido de baixo e outro de alto grau de imposição: caneta (baixo) e roupas secas ou banho (alto); de outro, suscitaram percepções diversas também um pedido de baixo e outro de alto grau de imposição: copo d'água (baixo) e celular (alto).

No caso dos pedidos que causaram percepções análogas entre brasileiros e italianos, retomando as observações que fizemos sobre os dados brutos, muito embora houvesse cinco níveis na escala de avaliação, ambos os grupos selecionaram pela maior quantidade de vezes exatamente o mesmo nível de cortesia: para o pedido do vídeo 1 (caneta + ) o nível médio-alto (4), para os de número 2 (caneta - ) e 7 (temporal + ) o nível médio (3) e, para o vídeo 8 (temporal - ), o nível alto (5). Levando em consideração a diferença entre as médias por grupo dos níveis de cortesia presente em cada um dos pedidos, os valores se mostraram pouco relevantes, sempre menores que 0,5 , sendo que entre aqueles que suscitaram percepções diversas a diferença era maior que 0,5 .

Quanto às diferenças entre os grupos BR e IT no que se refere à percepção da cortesia presente nos pedidos 3 (celular +), 4 (celular - ), 5 (água + ) e 6 (água - ), um dado importante a ser citado é que os brasileiros avaliaram os pedidos de modo mais positivo que os italianos: tanto os níveis de cortesia selecionados mais vezes quanto as médias de todos os 
níveis selecionados por eles eram maiores para os brasileiros em relação aos italianos. É importante ressaltar, porém, que a diferença entre os dois grupos não se mostrou muito grande, visto que, se pensarmos nos níveis de cortesia, os italianos, em média, selecionavam mais aquele imediatamente abaixo na escala de avaliação de 1 a 5.

Para entender como as variáveis de que temos falado se relacionam com os níveis de cortesia atribuídos aos pedidos, é necessário retomar os resultados da regressão realizada com a ANOVA. A partir dessa observação, podemos também responder a nossa segunda pergunta de pesquisa: se é possível reconhecer alguma correlação entre as diferentes categorias e os níveis de cortesia. Dividiremos a resposta a essa pergunta em duas partes: inicialmente, falaremos da correlação entre as variáveis e o nível de cortesia geral para, então, explicitar como essa correlação se dá em entre os vídeos que apresentaram percepções análogas e diversas.

O agradecimento, utilizado em todos os pedidos, foi a variável que exerceu maior impacto, e positivo, sobre o nível de cortesia em geral. Naturalmente presente em todos os vídeos, a entoação foi a segunda variável com maior impacto positivo, seguida pelo grau de imposição. Os minimizadores foram utilizados apenas nos vídeos 3 e 8 (celular + e temporal ), porém, ainda assim contribuíram a aumentar o nível de cortesia geral. Algo semelhante ocorreu com o imperfeito, que, utilizado apenas no vídeo $1($ caneta +$)$, surtiu efeito análogo ao dos minimizadores.

As fórmulas de cortesia, empregadas nos vídeos 1 e 2 (caneta $+e-$ ), ao contrário dos cinco modificadores citados até agora, tiveram um coeficiente B negativo, diminuindo, portanto, o nível de cortesia geral. Seguiu a mesma tendência o condicional, também utilizado em dois vídeos (4 e 8, celular - e temporal -), com coeficiente $\mathrm{B}=-0,061$. Os reforçadores, por outro lado, foram utilizados em cinco dos oito vídeos e também exerceram um impacto negativo sobre a cortesia geral.

Comentaremos agora os resultados relativos ao efeito das variáveis sobre os níveis de cortesia atribuído aos pedidos em particular, começando por aqueles que causaram percepções análogas.

Influenciaram mais significativamente a avaliação do nível de cortesia presente no pedido do vídeo $1($ caneta + ) a entoação, que teve impacto positivo, e a forma de tratamento nesse caso o tu -, com impacto negativo, explicado por uma possível falha no entendimento do tipo de relação existente entre as interlocutoras. Sobre o vídeo número 2 (caneta - ), em que, no 
ato principal, não foram utilizados modificadores, apenas os agradecimentos tiveram impacto significativo e positivo $(B=0,371)$, contribuindo a fazer com que os informantes percebessem o pedido como mais cortês.

O teste ANOVA indicou que, para o pedido do vídeo 7 (temporal +), três variáveis foram significativas e influenciaram mais consideravelmente a percepção de brasileiros e italianos. Os verbos modais, ausentes no pedido em questão, e o grau de imposição alto do pedido tiveram $\mathrm{B}=0,196$ e $\mathrm{B}=0,204$, respectivamente, e contribuíram a causar uma boa percepção. Isso pode significar que, tendo em vista a gravidade do pedido, optar por não utilizar um verbo modal - estratégia recorrente de atenuar pedidos - não representa um risco ao bom andamento da interação e ao sucesso do pedido. A terceira variável significante foi a entoação, e apenas nesse vídeo ela causou um impacto negativo $(B=-0,239)$, enquanto em todos os outros para os quais se mostrou significante o efeito foi positivo. O último dos vídeos a causar percepção semelhante entre BR e IT foi o de número 8 (temporal - ), para o qual apenas as fórmulas dubitativas $(\mathrm{Q} 12)$ foram significantes $(\mathrm{B}=0,247)$ indicando que, possivelmente, mostrar-se em dúvida quanto à possibilidade de o pedido ser atendido foi determinante para uma percepção positiva da cortesia.

Passando aos casos em que BR e IT divergiram, sobre a percepção cortesia presente no pedido contido no vídeo número 3 (celular + ), nenhuma variável apresentou $\mathrm{p}<0,05$ e, portanto, impacto significante. Isso não quer dizer que elas não tenham tido qualquer influência sobre o nível de cortesia atribuído ao pedido, mas que nenhuma variável chegou a alcançar o índice de confiança de $95 \%$ preestabelecido quando do início da análise dos dados.

Entre os oito vídeos, aquele que mais apresentou variáveis significantes para a percepção da cortesia que suscitou foi o 4 (celular -), com alto grau de imposição e grau de familiaridade médio-baixo. Tiveram impacto positivo a presença dos agradecimentos $(\mathrm{Q} 2, \mathrm{~B}=$ $0,321)$, a ausência de minimizadores $(\mathrm{Q} 5, \mathrm{~B}=0,282)$ e preenchimentos $(\mathrm{Q} 7, \mathrm{~B}=0,253)$ e o uso da forma de tratamento lei $(\mathrm{Q} 19, \mathrm{~B}=0,252)$. Por outro lado, impactaram negativamente a percepção da cortesia a presença de reforçadores $(\mathrm{Q} 6, \mathrm{~B}=-0,256)$ e o grau de familiaridade médio-baixo $(\mathrm{Q} 14, \mathrm{~B}=-0,223)$. Considerando os resultados relativos especialmente às variáveis que tiveram Beta coeficiente negativo, podemos pensar que utilizar meios de reforçar a necessidade de obter o favor pedido a alguém com quem se tem pouca familiaridade pode soar, de alguma maneira, descortês. 
Os dois últimos vídeos para os quais a percepção de BR e IT foram divergentes são os 5 e 6, ambos um pedido de copo d'água. Para os dois, a única variável que se mostrou significante foi a entoação ( $\mathrm{Q} 16, \mathrm{~B}=0,334$ e $\mathrm{B}=0,323$, respectivamente).

Respondidas as perguntas de pesquisa, façamos algumas considerações. O primeiro aspecto que podemos destacar dos resultados relativos à influência das variáveis de que tratamos sobre o nível de cortesia é que, ainda que alguns pedidos tenham sido realizados com diversos modificadores, não necessariamente eles se mostrarão significantes para determinar a percepção dos informantes. O vídeo 1 (caneta + ), por exemplo, foi realizado com sete modificadores (agradecimento, fórmula de cortesia, duvidador, fórmula de apelo, imperfeito, verbo modal e justificativa). No entanto, apenas entoação e forma de tratamento foram de fato significantes para a percepção de brasileiros e italianos.

Outro dado importante é que, de acordo com nossos dados, uma grande quantidade de modificadores não implica uma alta percepção de cortesia, visto que, como ocorreu no pedido do vídeo $1($ caneta +$)$, 5 e 6 (água $+e-)$, apesar dos muitos modificadores, a média atribuída pelos informantes a todos eles ficou na casa dos três pontos (nível médio de cortesia). Isso significaria que nem sempre utilizar procedimentos de atenuação, como o uso de modificadores, garante um efeito de cortesia, o que nos remete ao que afirmam Briz e Albelda (2013) a respeito do fato de a atenuação ser uma categoria pragmática, mas não exatamente sinônimo de cortesia.

Também emergiu dos dados que, embora tenhamos organizado a amostra com base, entre outros aspectos, no grau de imposição do pedido e de familiaridade entre os falantes, esses fatores não se mostraram relevantes para determinar a percepção da cortesia. Isso porque, como vimos na descrição dos resultados relativos aos pedidos, o grau de familiaridade só foi significante (e com impacto negativo) para o vídeo 4 (celular - ) e o grau de imposição o foi para o vídeo 7 (temporal + ).

A partir do corpus que coletamos, pudemos observar alguns padrões e responder às perguntas de pesquisa. No entanto, apesar de termos coletado uma quantidade de dados que nos permitiu ter uma amostra válida estatisticamente, seguindo o que havíamos definido na metodologia, o tamanho da amostra (40 brasileiros e 51 italianos) pode ter dificultado a produção de resultados mais robustos. Essa constatação vem do fato de, por exemplo, para o vídeo 3, não termos tido nenhuma variável significante e de para os vídeos 5 e 6 termos tido apenas uma. 
Isso nos leva a outra questão que pode ter criado dificuldades: o número de variáveis que apresentamos aos informantes como possibilidade de justificar o nível de cortesia selecionado para cada pedido. Foram 19 ao todo, o que pode ter feito com que as respostas tenham tido um alto grau de dispersão. Por outro lado, nos casos em que houve variáveis significantes de acordo com a ANOVA, podemos dizer com segurança que, apesar do número de informantes e da quantidade de variáveis, a correlação era realmente forte. Desse modo, poderia ser produtivo, no caso de continuar uma investigação dessa natureza, antes de mais nada, limitar o número de variáveis a serem apresentadas aos informantes e também ampliar o corpus, tentando também equilibrar melhor a amostra de acordo com o gênero, pois como vimos na seção 3.7 deste trabalho, maioria dos indivíduos era do gênero feminino, tanto entre brasileiros quanto entre italianos. 


\section{Referências}

ABDOLREZAPOUR, P.; ESLAMI-RASEKH, A. (2010). A Cross-Cultural Study of Perception of Politeness by Iranian and American in Request Forms. Pakistan Journal of Social Sciences, vol. 7, n. 2, p. 164-169.

ANDERSON, L. et al. (1990). The Pixi corpora: Bookshop encounters in English and Italian. Bologna: Cooperativa Libreria Universitaria Editrice.

ARMENGAUD, F. (2006). A Pragmática. Tradução de Marcos Marcionilo. São Paulo: Parábola Editorial.

ASTON, G. (1988). Negotiating Service: Studies in the Discourse of Bookshop Encounters. Bologna: Cooperativa Libraria Universitaria Editrice Bologna.

ATKIN, A. (2013). Peirce's Theory of Signs. In ZALTA, E. (ed). The Stanford Encyclopedia of Philosophy.

URL <https://plato.stanford.edu/archives/sum2013/entries/peirce-semiotics/>.

AUSTIN, J. L. (1962). How to do things with words. Oxford: Clarendon Press.

BAR-HILLEL, Y. (1971). Out of the pragmatic wastebasket. Linguistic Inquiry, n.2, p. 401407.

BAZZANELLA, Carla (2008). Linguistica e pragmatica del linguaggio: un'introduzione. Roma-Bari: Editori Laterza.

BETTONI, C. (2006). Usare un'altra lingua: guida alla pragmatica interculturale. Roma-Bari: Laterza.

BLUM-KULKA, S.; HOUSE, J. (1989). Cross-cultural and situational variation in requestive behavior. In BLUM-KULKA, S.; HOUSE, J.; KASPER, G. (org.). Cross-Cultural pragmatics: Requests and Apologies. Norwood, NJ: Ablex, 123-154.

BLUM-KULKA, S.; HOUSE, J.; KASPER, G. (1989). Investigating Cross-Cultural Pragmatics: an Introductory Overview. In BLUM-KULKA, S.; HOUSE, J.; KASPER, G. (org.). Cross-Cultural pragmatics: Requests and Apologies. Norwood, NJ: Ablex, p. 1-28.

BLUM-KULKA, S.; OLSHTAIN, E. (1984). Requests and apologies: a cross-cultural study of speech act realization patterns (CCSARP). Applied Linguistics, vol. 5, n. 3, p. 196-213.

BORREGUERO, M.; PERNAS, P. (2009). Cortesia e scortesia in un contesto di apprendimento linguistico: la gestione dei turni. In PETTORINO, M; GIANNINI, A; DOVETTO, F.M. (orgs.). Atti del Terzo congresso internazionale de Gruppo di Studio sulla Comunicazione Parlata, vol. 1. Napoli: Università degli Studi di Napoli L'Orientale, p. 228-248.

BRAVO, D. (2001). Sobre la cortesía, estratégica y conversacional en español. Oralia, vol. 4, p. 299-314. 
(2003). Actividades de cortesía, imagen social y contextos socioculturales: una introducción. Actas del Primer Coloquio del programa EDICE. La perspectiva no etnocentrista de la cortesía de la cortesía: identidad sociocultural de las comunidades hispanohablantes. Universidad de Estocolmo, p. 98-108.

(2005). Estudios de la (des) cortesía en español. Buenos Aires: Editorial Dunken.

BRIZ, A. (2004). Cortesía verbal codificada y cortesía verbal interpretada. In BRAVO, D.; BRIZ, A. (orgs). Pragmática sociocultural: análisis del discurso de cortesía en español. Barcellona: Ariel, p. 67-93.

BRIZ, A.; ALBELDA, M. (2013). Una propuesta teórica y metodológica para el análisis de la atenuación linguiística en español y portugués. La base de un proyecto común (ES.POR.ATENUACIÓN). Onomázein, vol. 28, p. 288-319.

BROWN, P. (2015). Politeness and Language. International Encyclopedia of the Social \& Behavioral Sciences, $2^{a}$ edição, vol. 18, p. 326-330.

BROWN, P.; LEVINSON, S. C. (1987). Politeness: some universals in language use. Cambridge: Cambridge University Press.

CAMILlERI, A; DE MAURO, T. (2013). La lingua batte dove il dente duole. Roma-Bari: Editori Laterza, p. 111.

CARREL, P.; KONNEKER, B. (1981). Politeness: comparing native and nonnative judgments. Language Learning - A Journal of Applied Linguistics, Michigan, vol. 31, n. 1, p. 17-29.

COHEN, L.; MANION, L.; MORRISON, K. (2007). Research Methods in Education. New York: Routledge.

CRUZ, M. et al (2017). The role of intonation and visual cues in the perception of sentence types: evidence from European Portuguese varieties. Laboratory Phonology: Journal of the Association for Laboratory Phonology 8(1): 23, p. 1-24.

CULPEPER, J. (1996). Towards an anatomy of impoliteness. Journal of Pragmatics, vol. 25, p. 349-367.

CULPEPER, J.; BOUSFIELD, D.; WICHMANN, A. (2003). Impoliteness revisited: with special reference to dynamic and prosodic aspects. Journal of Pragmatics, vol. 35, p. 15451579.

DASCAL, M. (1979). O lugar da pragmática na teoria da linguagem. Acta Semiótica et Lingvistica, v. 3, n.1, p. 9-24.

DÖRNYEI, Z. (2007). Research methods in applied linguistics: quantitative, qualitative and mixed methodologies. Oxford, England: Oxford University Press.

DÖRNYEI, Z; CSIZÉR, K. (2012). How to Design and Analyze Surveys in Second Language Acquisition Research. In: MACKEY; A; GASS, S. (orgs.). Research Methods in Second Language Acquisition: A Practical Guide. Oxford: Blackwell, p. 74-94. 
ESCANDELL-VIDAL, M. V. (1996). Introducción a la Pragmática. Barcelona: Editorial Ariel.

FAERCH, C.; KASPER, G. (1989). Internal and External Modification in Interlanguage Request Realization. In BLUM-KULKA, S.; HOUSE, J.; KASPER, G. (ed.). Cross-Cultural pragmatics: Requests and Apologies. Norwood, NJ: Ablex, p. 221-246.

FIORIN, J. L. (2007). A linguagem em uso. In: FIORIN, José Luiz (org.) Introdução à Linguística I. $5^{\text {a }}$ ed. São Paulo: Contexto, p. 165-186.

FRASER, B. (1990). Perspectives on Politeness. Journal of Pragmatics, vol. 14, p. 219-236.

GHASEMPOUR, B.; FARNIA, M. (2016). A comparative study of perception of (im)politeness between Iranian EFL learners and Americans: the case of request speech act. Studies about languages n. 29, p. 19-30.

GOFFMAN, E. (2011 [1967]). Ritual de Interação: ensaios sobre o comportamento face a face. Tradução de Fábio Rodrigues Ribeiro da Silva. Petrópolis: Vozes. (Título original: Interaction Ritual: essays on face-to-face behavior. New York: Garden City).

GRICE, H. P. (1989 [1967]). Logic and conversation. In Studies in the Way of Words, 22-40. Cambridge, MA: Harvard University Press.

GROTJAHN, R. (1987). On the methodological basis of introspective methods. In FAERCH, C.; KASPER, G. (orgs). Instrospection in Second Language Research. Clevedon Avon: Multilingual Matters.

GRUPO A.Ma.Dis (2008). Marcadores discursivos y cortesía lingüística en la interacción de aprendices de italiano L2. In BRIZ GÓMEZ, A. et al. (orgs.). Cortesía e conversación: de lo escrito al oral, III Coloquio internacional del programa EDICE, 22-26 de novembro de 2006. Valencia: Universitat de València, p. 712-729.

GU, Y. (1990). Politeness phenomena in modern Chinese. Journal of Pragmatics, vol. 14, p. 237-257.

HANSSON, B. (1974). A Program for Pragmatics. In STENLUND, S. et al (orgs). Logical Theory and Semantic Analysis. Dordrecht: Springer, p. 163-174.

HATCH, E.; LAZARATON, A. (1991). The research manual: Design and statistics for applied linguistics. New York, NY: Newbury House.

HILL, B. et al. (1986). Universals of Linguistic Politeness. Quantitative evidence from Japanese and American English. Journal of Pragmatics, vol. 10, p. 347-371.

HORN, L.; WARD, G. (2008). The Handbook of Pragmatics. Oxford: Blackwell Publishing.

HOOKWAY, C. (2016). Pragmatism. In ZALTA, E. (ed.) The Stanford Encyclopedia of Philosophy. URL <https://plato.stanford.edu/archives/sum2016/entries/pragmatism/>. 
KRAFT, B.; GELUYKENS, R. (2007). Cross-Cultural Pragmatics of Interlanguage English. München: Lincom Europa.

LABOV, W. (1972). Sociolinguistic Patterns. Oxford: Basil Blackwell.

LAKOFF, R. (1998). La lógica de la cortesía, o acuérdate de dar las gracias. Tradução de Marcos Cánovas. In JULIO, M.T.; MUÑOZ, R. (orgs). Textos clásicos de pragmática. Madrid: Arco/Libros, p. 259-278. (Título original: The logic of politeness, or minding your p's and q's. Chicago Linguistic Society, v.9, p. 292-305).

LECOMPTE, M.; GOETZ, J. (1982). Problems of reliability and validity in ethnographic research. Review of Educational Research, vol. 52, n. 1, p. 31-60.

LEECH, G. N. (1983). Principles of Pragmatics. London: Longman.

. (2014). The Pragmatics of Politeness. New York: Oxford University Press.

LEVINSON, S. (2007 [1983]). Pragmática. Tradução de Luis Carlos Borges, Aníbal Mari. São Paulo: Martins Fontes. (Título original: Pragmatics. Cambridge University Press)

LISPECTOR, C (1964 [2009]). A Paixão Segundo G.H. Rio de Janeiro: Editora Rocco, p. 176.

MAO, L. R. (1994). Beyond politeness theory: 'Face' revisited and renewed. Journal of Pragmatics, vol. 21, p. 451-486.

MARIOTTINI, Laura (2007). La Cortesia. Roma: Carocci editore.

MARKEE, N. (1994). Toward an ethnomethodological respecification of second-language acquisition studies. In TARONE, E.; GASS, S; COHEN, A. (orgs). Research Methodology in Second-Language Acquisition. New Jersey: Lawrence Elbaum Associates Publishers.

MATSUMOTO, Y. (1988). Reexamination of the universality of face: politeness phenomena in Japanese. Journal of Pragmatics, vol. 12, p. 403-426.

MATSUURA, H. (1998). Japanese EFL learners' perception of politeness in low imposition requests. JALT Journal, Vol. 20, n.1, p. 33-48.

MORRIS, C. (1938). Foundations of the Theory of Signs. Chicago: Chicago University Press.

NUNAN, D. (1992). Research Methods in Language Learning. New York: Cambridge University Press.

NUZZO, E. (2009). Richiedere in italiano L1 e L2: Strategie di attenuazione della forza illocutoria. In PETTORINO, M; GIANNINI, A; DOVETTO, F.M. (orgs.). Atti del Terzo congresso internazionale de Gruppo di Studio sulla Comunicazione Parlata, vol. 1. Napoli: Università degli Studi di Napoli L'Orientale, p. 513-532.

NUZZO, E. (2012). Imparare ad agire in italiano L2: uno studio con giovani immigrate. In NUZZO, E.; GAUCI, P. Insegnare la pragmatica in italiano L2: Recenti ricerche nella prospettiva della teoria degli atti linguistici. Roma: Carocci editore. 
NUZZO, E.; GAUCI, P. (2012). Insegnare la pragmatica in italiano L2: Recenti ricerche nella prospettiva della teoria degli atti linguistici. Roma: Carocci editore.

NUZZO, E.; RASTELLI, S. (2009). "Didattica acquisizionale" e cortesia linguistica in italiano L2. Cuadernos de Filología Italiana, vol. 16, 13-30.

NUZZO, E; SANTORO, E. (2017). Apprendimento, insegnamento e uso di competenze pragmatiche in italiano L2/LS: la ricerca a partire dagli anni Duemila. EuroAmerican Journal of Applied Linguistics and Languages, vol. 4, issue 2, p. 1-27.

PACHECO, V. (2011). Percepção de Ênfase e Atenuação: O Papel dos Movimentos Faciais e Corporais. In REIS, C. (ed.). Anais do III Colóquio Brasileiro de Prosódia da Fala, p. 94-96.

RAJAGOPALAN, K. (2010). A nova pragmática: fases e feições de um fazer. São Paulo: Parábola editorial.

SACKS, H.; SCHLEGOFF, E.A., JEFFERSON, G. (1974). A simplest systematics for the organization of Turn-taking for conversation. Language, vol. 50, n. 4, part 1, p. 696-735.

SANTORO, E. (2012). A constituição de um corpus de italiano falado para o estudo de pedidos e pedidos de desculpas: considerações sobre a validade interna e externa dos dados. In MELLO, H.; PETTORINO, M.; RASO, T. (orgs.). Proceedings of the VII GSCP International Conference: Speech and Corpora. Firenze: Firenze University Press, 103-107.

SANTORO, E. (2017). Richieste e attenuazione: un confronto tra italiano e portoghese brasiliano. Normas, vol. 7, n. 2, p. 179-204.

SANTORO, E.; KULIKOWSKI M. Z.; SILVA, L. A. (2017). Pragmática sociocultural: a elaboração de um corpus. In CABRAL; A. L. T.; SEARA, I. R.; GUARANHA, M. F. (orgs.). Descortesia e cortesia: expressão de culturas. São Paulo: Cortez Editora.

SBISÀ, M. (2009 [1989]). Linguaggio, ragione e interazione: per una pragmatica degli atti linguistici. Edição digital: Edizioni Università di Trieste.

SCHNEIDER, K. P. (2010). Variational pragmatics. In ÖSTMAN, J.; VERSCHUEREN, J. (orgs.). Handbook of Pragmatics. Amsterdam: John Benjamins, p.

SEARLE, J. (1969). Speech Acts. An Essay in the Philosophy of Language. New York: Oxford University Press.

(1979). Expression and Meaning. Studies in the Theory of Speech Acts. Cambridge: Cambridge University Press.

SILVA NETO, M; SANTORO, E. (2015). A cortesia em pedidos em italiano: um estudo comparativo da percepção de brasileiros e italianos. Revista de Italianística, n. 30, p. 80-110.

SPADOTTO, L.; SANTORO, E. (2016). Modificatori e atti di supporto come strategie di mitigazione nelle richieste di parlanti nativi: un contributo per l'insegnamento dell'italiano L2. 
In SANTORO, E; VEDDER, I. (orgs). Pragmatica e interculturalità in italiano lingua seconda. Firenze: Franco Cesati, p. 29-40.

STALNAKER, R. (1972). Pragmatics. In DAVIDSON, D.; HARMAN, G. (orgs). Semantics of Natural Language. Dordrecht: Reidel, p. 380-97.

TARONE, E. (1994). A summary: research approaches in studying second language acquisition or "if the shoe fits...". In TARONE, E.; GASS, S; COHEN, A. (orgs). Research Methodology in Second-Language Acquisition. New Jersey: Lawrence Elbaum Associates Publishers.

TERKOURAFI, M. (2005). Beyond the micro-level in politeness research. Journal of Politeness Research, vol. 1, p. 237-262.

THOMAS, J. (1983). Cross-Cultural Pragmatic Failure. Applied Linguistics, 4, p. 91-112.

TRASK, R. L. (2004). Dicionário de linguagem e linguística. Tradução de Rodolfo Ilari. 3.ed. São Paulo: Contexto.

VEDDER, I. (2007). Competenza pragmatica e complessità sintattica in italiano L2 - l'uso dei modificatori nelle richieste. Lingui stica e Filologia, vol. 25, Università degli Studi di Bergamo, p. $99-123$.

VERSCHUEREN, J. (2016). Contrastive Pragmatics. In ÖSTMAN, J.; VERSCHUEREN, J. (orgs.). Handbook of Pragmatics. Amsterdam: John Benjamins, p. 1-34.

VILLAÇA, I. G.; BENTES, A. C. (2008). Aspectos da cortesia na interação face a face. In: PRETI, Dino (org). Cortesia Verbal. São Paulo: Editora Humanitas, p. 19-48.

WALTERS, J. (1979). The perception of politeness in English and Spanish. In YORIO, C.; PERKINS, K.; SCHANTER, J. (eds.). On TESOL '79: The learner in focus. Washington, DC: TESOL, p. 288-296.

WEIZMAN, E. (1993). Interlanguage Requestive Hints. In BLUM-KULKA, S.; HOUSE, J.; KASPER, G. (orgs.). Interlanguage Pragmatics. New York: Oxford University Press, p. 123137.

WIERZBICKA, A. (1991). Cross-cultural Pragmatics: The Semantics of Human Interaction. Berlin: Mouton de Gruyter. 


\section{ANEXO I - NORMAS DE TRANSCRIÇÃO DOS VÍDEOS}

\begin{tabular}{|c|c|}
\hline $\begin{array}{l}\text { Smile voice e palavras pronunciadas enquanto se } \\
\text { ri }\end{array}$ & £palavra£ \\
\hline Riso vocalizado & hehehe, hahaha, hihihi \\
\hline Riso não vocalizado & £hhh£ \\
\hline $\begin{array}{lllll}\begin{array}{l}\text { Aumento } \\
\text { entonação }\end{array} & & \text { diminuição } & \text { repentinos } & \text { da }\end{array}$ & / ascendente, $\backslash$ descendente \\
\hline $\begin{array}{l}\text { Entonação final descendente } \\
\text { necessariamente uma afirmação) }\end{array}$ & . \\
\hline Entonação final suspensa & , \\
\hline $\begin{array}{l}\text { Entonação final ascendente } \\
\text { necessariamente uma pergunta) }\end{array}$ & $?$ \\
\hline $\begin{array}{l}\text { Entonação ascendente claramente limitadaa uma } \\
\text { só palavra ou a um trecho de frase. (indicar o } \\
\text { início e o final). }\end{array}$ & ?palavra/trecho de frase? \\
\hline $\begin{array}{l}\text { Inspiração (duração proporcional ao número de } \\
\text { h's) }\end{array}$ & .hhh \\
\hline $\begin{array}{l}\text { Expiração (duração proporcional ao número de } \\
\text { h's) }\end{array}$ & hhhh \\
\hline Texto acelerado & $>$ texto $<$ \\
\hline Texto muito acelerado & $>>$ texto<< \\
\hline Texto desacelerado & $<$ texto $>$ \\
\hline Texto muito desacelerado & $\langle<$ texto $\rangle>$ \\
\hline Volume baixo & ${ }^{\circ}$ palavra $^{\circ}$ \\
\hline Volume alto & PALAVRA \\
\hline Prolongamento de som & pala:::vra \\
\hline Inaudível (um x por fonema) & $\operatorname{xxxxxx}$ \\
\hline Transcrição dúbia & (palavra) \\
\hline Truncamento comgolpe deglote & pala- \\
\hline Truncamento sem golpe de glote & pala \\
\hline Pausas de menos de 0.2 segundos & $\#$ \\
\hline Pausas mais longas & $\begin{array}{l}\# 0 \_2, \# 3 \_5 \text { (\#\#\#\#\# umjogo da velhaa cada } \\
0.5)\end{array}$ \\
\hline Ênfase sobre uma palavra ou frase & !palavra! !todaa frase! \\
\hline Latching & $=$ no final do primeiro turno e início do segundo \\
\hline Início de sobreposição & {[} \\
\hline Final de sobreposição & ] \\
\hline Tempo de 05.00 minutos (acada cinco minutos) & $\%$ com \\
\hline Comentários do transcritor (em inglês) & $\begin{array}{l}\text { \%com em turnos isolados, se adentro do turno } \\
\text { entreparêntese duplo((comentário) })\end{array}$ \\
\hline Sinais não verbais de aprovação & $\sqrt{\text { (repetidos se os sons forem separados) }}$ \\
\hline
\end{tabular}




\section{ANEXO II: TRANSCRIÇÃO DOS VÍDEOS}

\section{Vídeo 1 - baixo grau de imposição/ grau de familiaridade médio-alto}

A ah vedi Tinuccia che bei::: che begli appartamenti che ci so:no \# ah: guarda questo quasi quasi mi interessa .h ehm:: volevo prendere il numero di telefono di:.: di:: di questo: avviso \# però mi sa che non ho non ho una penna

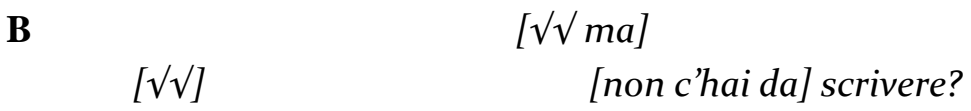

A no non ho da scri- eh \#\# hai per caso una penna per piacere?

B [ma perché] [sì guarda io la penna te la]

A

[ok]

ah ecco grazie

B [ecco] aspetta

A [ah] ah grazie \# oh!che carina! \# proprio da borsa

B $£$ sì::£

A \#\# ok \#\# grazie

A Olha Tinuccia, que... que apartamentos bonitos tem aqui. Ah, olha, esse quase, quase me interessa. Eu queria anotar o número de telefone dessa, dessa placa, mas... acho que não tenho uma caneta.

B Você não tem com o que escrever?

A Não, não tenho... Você tem, por acaso, uma caneta, por favor?

B Mas por que... Sim, olha, eu te dou a caneta

A Ok... Ah, aqui está, obrigada!

B Aqui está... Espera!

A Ah, ah obrigada! Oh, que bonitinha, de bolsa mesmo...

B Sim...

A Ok, obrigada! 


\section{Vídeo 2: baixo grau de imposição/ grau de familiaridade médio-baixo}

\section{A eh:: mi scusi ha una penna per scrivere?}

B [si]

B no mi dispiace non ce l'ho una penna:: se le serve: scrivere può scrivere su un telefono è la stessa cosa

A

[eh: mi dispiace] non ho

neanche il telefono

B eh no mi dispiace il mio non lo posso dare altrimenti è inutile

A [va bene] [ha ragione]

B $£$ le regalo il telefono per scrivere£

A [£grazie lo stesso£]

B Arrivederci ciao

A [£grazie lo stesso£]

A Eh... me desculpe, tem uma caneta para escrever?

B $\operatorname{Sim} .$.

B Não, sinto muito, não tenho uma caneta, mas se precisa escrever, pode escrever no telefone, é a mesma coisa...

A É... Não, sinto muito, não tenho nem um telefone...

B Tudo bem... É... Não, sinto muito, mas não posso dar o meu, é inútil que eu lhe dê o meu telefone para escrever...

A Tem razão... Agradeço igualmente, agradeço igualmente... 
Vídeo 3: alto grau de imposição/ grau de familiaridade médio-alto

A senti ascolta aspetta che >debbo fare una telefonata $<$ un attimo \# aspetta aspetta B [beh]

A .h ahi è scarico

B vuoi il mio? vuoi il mio?

A [tsc] [sì] sì sì: dammelo perché è urgente la telefonata mi dai il tuo un attimo?

B [si] \# [aspetta aspetta \# devo sbloccarlo te lo passo ecco]

A si è libero

B $o k$

A eh grazie \#\# grazie grazie

A Ouve, escuta, espera que eu tenho que fazer uma ligação um minuto. Espera, espera. B $\operatorname{Sim} . .$.

A Ai, está descarregado.

B Quer o meu? Quer o meu?

A Sim, sim, me dá porque é urgente a ligação. Me dá o seu um minuto?

B Sim. Espera, espera... Tenho que desbloquear... te dou... aqui está.

A Está desbloqueado?

B Ok.

A É... obrigado. Obrigado, obrigado. 
Vídeo 4 - alto grau de imposição/ grau de familiaridade médio-baixo A scusi un attimo \# ?che per caso avrebbe un cellulare? sa il mio non mi sta funzionando
B [mi dica signora] [? cellula::re?] !si certo!

A vediamo un poco se riesco a fare una telefonata perché è una cosa urgente: \# ce l'ha i soldi nel telefono?

B

chiamata signora?] \# penso che ci sia un po' di credito

[deve fare una

A

B

B faccia pure

A grazie

B ci mancherebbe

A Com licença, um momento. Por acaso (o senhor) teria um celular? Sabe, o meu não está funcionando

B Me diga, senhora. Um celular? Sim, claro.

A Vejamos se eu consigo fazer uma ligação porque é uma coisa urgente. Tem crédito o seu celular?

A A senhora precisa fazer uma ligação? Acho que tem um pouco de crédito.

A Posso ligar?

B Claro.

A Obrigada.

B Não seja por isso. 
Vídeo 5 - baixo grau de imposição/ grau de familiaridade médio-alto

A ciao
B [ciao] Mariana vieni

A [ciao] grazie (per)messo?

B come stai

A [ciao] bene \#.hh a parte il caldo infatti sono:

B [vien vien t'accomodi (sic) accomodati]

A grazie \# .h scusami mi dai un bicchiere d'acqua subito subito che h sono accaldati:ssima B

l'acqua?]

[sì sì che ti porto oltre

A sì, un bicchiere d'acqua

B solo acqua? sicura?

A [ $\quad$ xx grazie per] il momento sì grazie

B va bene \# ok \# arrivo subito?

A

[gra]zie \# mi siedo

A Oi.

B Oi, Mariana, entra.

A Oi. Obrigada. Licença?

B Como você está?

A Oi. Bem, fora o calor. Na verdade, eu estou...

B Vem, vem, se acomode, se acomode.

A Obrigada. Desculpa, me dá um copo d'água rápido, rápido, porque eu estou morrendo de calor?

B Sim, sim. O que eu te trago além de água?

A Sim, um copo d'água.

B Só água? Tem certeza?

A Obrigada, por enquanto sim, obrigada.

B Tudo bem, ok, volto em um instante.

A Obrigada. Me sento... 


\section{Vídeo 6 - baixo grau de imposição/ grau de familiaridade médio-baixo}

A eh: buongiorno sono::

B [si accomodi prego] si accomodi eh:

A buongiorno, sono la rappresentante di::

B [le ho dato io (quest) sì: le ho dato] io l'impegno per venire sì

A ch le volevo\# presentare questo: questo contratto però:

B $\left[{ }^{\circ} i^{\circ}\right]$

A prima le devo chiedere un bicchiere d'acqua.

B ah: sicuro come no

A [me lo può dare?]

B come no

A [grazie] mille molto gentile

B mi scusi dell'acqua è finita proprio adesso io no:: non ci avevo nemmeno pensato

A

[gra]zie mille gentilissimo

B no no si figu:ri \# va be:ne

A Bom dia. Eu sou...

B Se acomode, por favor. Se acomode...

A Bom dia, eu sou a representante de...

B Fui eu quem... Sim, fui eu quem lhe pedi para vir, sim...

A Eu gostaria de lhe apresentar o contrato, mas...

B Sim.

A Primeiro eu devo lhe pedir um copo d'água.

B Sim, como não?

A O senhor pode me dar?

B Como não, como não...

A Muito obrigada, muito gentil.

B Sinto muito pela água, acabou agora há pouco e não tinha nem pensado nisso...

A Muito obrigada, gentilíssimo.

B Não, não, imagine, tudo bem. 


\section{Vídeo 7 - alto grau de imposição/ grau de familiaridade médio-alto}
A ${ }^{\circ}$ madonna ${ }^{\circ}$ Daniela sta diluvia:ndo guarda come mi sono tutta ba- B [ch'è successo? \# madonna \# senti] ti do:: l'asciugamani asciugati poi ti do il fon
A [sì sì no va beh ma:] non mi basta l'asciugamano dovrei spogliarmi e asciugare i vestiti
B [eh ti do la:::]

A dammi una vestaglia un pantalone tuo una maglietta

B [ti do:: ti do un vestito mio]

A sì sì qualcosa no guarda sono !bagnatissima!

B [dai ti porto un vestito]

B dai sì non ti preoccupare
A [prima che mi venga un influenza]
B [vatti a:: spogliare nel] frattempo?
[sì sì grazie grazie]

B io ti porto il vestito

A Nossa, Daniela, está caindo um dilúvio, olha como estou toda molhada!

B O que aconteceu? Nossa... Escuta, vou te dar uma toalha, você se seca e depois eu te dou um secador de cabelo.

A Sim, não, tudo bem... Mas não me basta uma toalha, eu teria que tirar, secar as roupas...

B Eu te dou a...

A Me dá um robe, uma calça, uma camiseta...

B Eu te dou, te dou um vestido meu.

A Sim, alguma coisa... Não, olha, estou ensopada!

B Eu te trago um vestido... Não se preocupe...

A Antes que eu pegue uma gripe

B Vai tirar a roupa enquanto isso

A Sim, sim, obrigada, obrigada.

B Eu te trago o vestido. 


\section{Vídeo 8 - alto grau de imposição/ grau de familiaridade médio-baixo}
A permesso \# ciao signora Anna

B buongiorno

A [?come va?]

B bene

A non::: non ti voglio salutare vedi come sono ridotta \# piove a dirotto terriccio tutta sporca B [oh mamma] \#

e:: non so ti vuoi

A [però non so come dirglielo] io avrei bisogno di:: cambiarmi di lavarmi se lei

B [ti vuoi to-]

A possibilmente mi da qualcosa di suo

B [sì: sì sì sì]

A [giusto per]

B ${ }^{\circ}$ sì sì sì sì

A [mi posso] fare una .h piccola doccia non so qualcosa

B $\quad\left[{ }^{\circ}\right.$ va beh $\left.{ }^{\circ}\right]$ \# il bagno è quello \# vai lì e vedi

A [?posso?]

B sì sì vai

A e no perché

B [n- no no] non ti preoccupare

A [grazie] grazie molto gentile

B

$\left[{ }^{\circ}\right.$ non ti preoccupa- $\left.{ }^{\circ}\right]$ adesso vedo di portarti

qualche cosa

A [sì::] grazie grazie

A Com licença. Oi, senhora Anna.

B Bom dia

A Como está?

B Bem.

A Não, não quero te cumprimentar, olha como eu estou, está chovendo muito, estou toda suja. B Minha nossa... Não sei, você quer se...

A Mas não sei como lhe dizer, eu precisaria me trocar, me lavar, se a senhora...

B Você quer...

A Possivelmente me der algo seu...

B Sim, sim, sim, sim...

A Só para...

B Sim, sim, sim, sim...

A Posso tomar um banho rápido, não sei, alguma coisa...

B O banheiro é ali, vai lá e vê...

A Posso?

B Sim, sim, vai...

A Não, porque...

B Não, não se preocupe.

A Muito obrigada, muito gentil.

B Não se preocupe... Agora vejo alguma coisa pra te trazer.

A Sim, obrigada, obrigada. 